\title{
تجليات الأنا والآخر \\ في عامريات ابن دراج القسطلّي الآنري
}

\author{
د/ محد حلمي البادي \\ أستاذ الأدب الأندلسي المساعد المديادي \\ كلية الآداب- جامعة كفر الشيخ الأدليخ
}




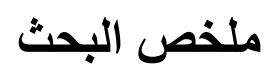

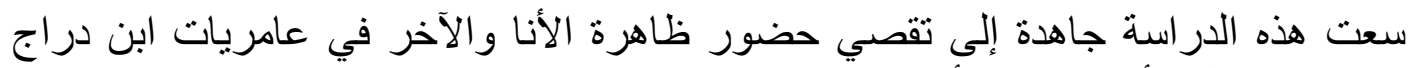

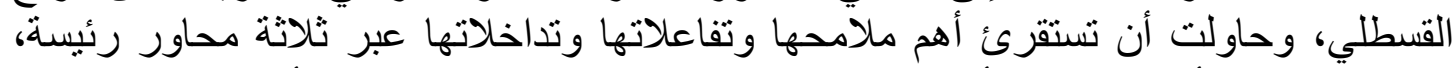

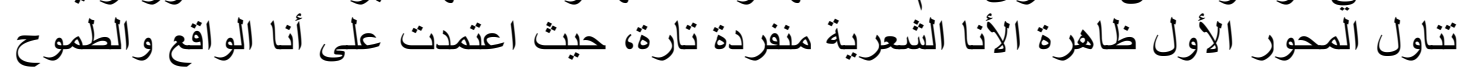

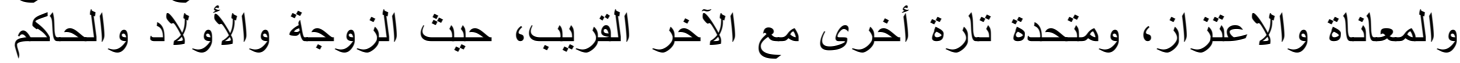

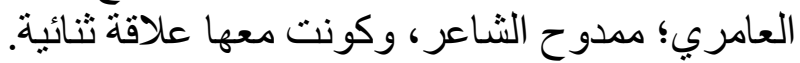

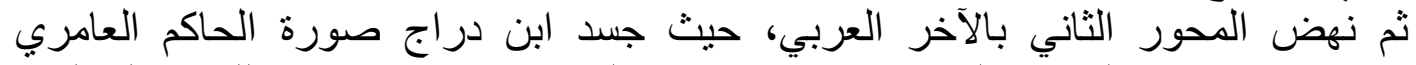

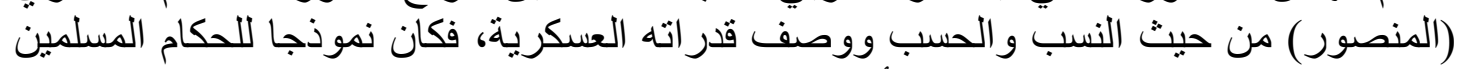

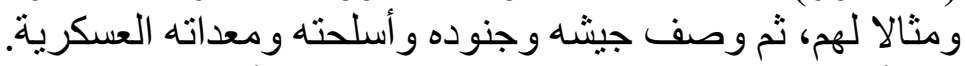

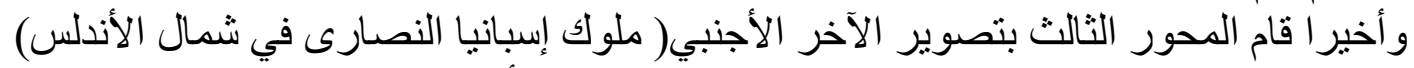

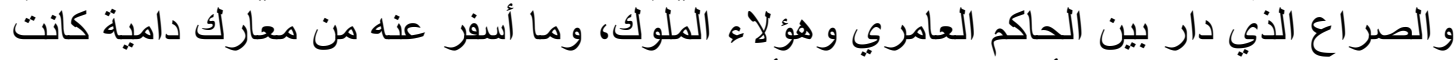
دائما في صالح المسلمين، أو تو افد السفراء الأجانب على المنصور طلئ طلبا للصلح و المهادنة. 


\section{مقدمة}

الحمد لله رب العالمين، و الصلاة و السلام على أثشرف الخلق أجمعين؛ سيدنا محمد عليه و على

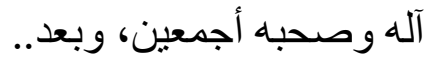

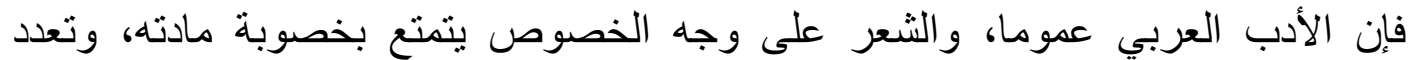

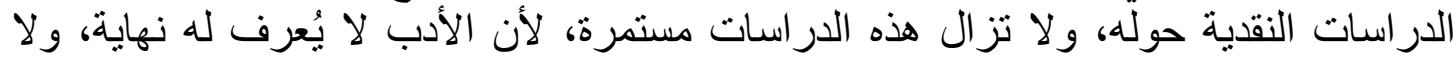

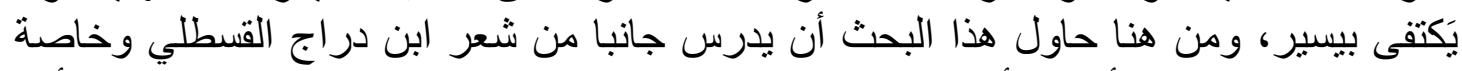

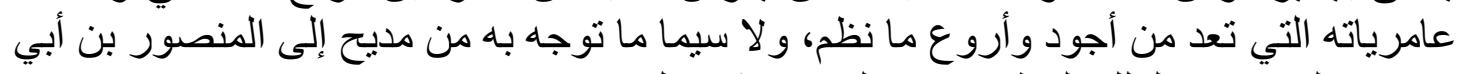

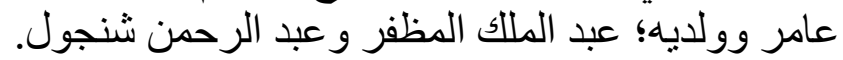

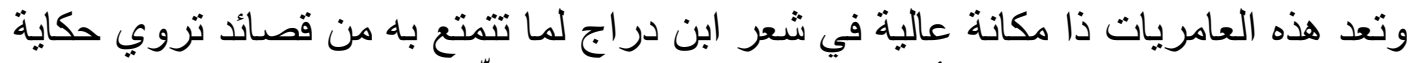

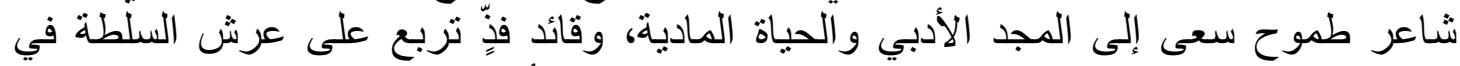

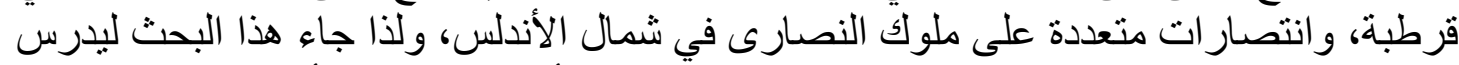

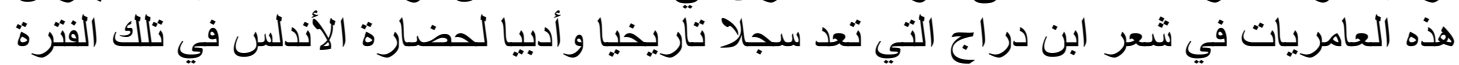

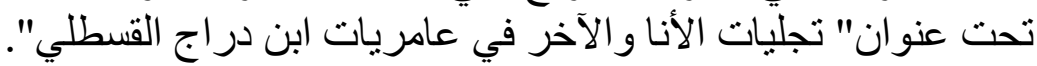

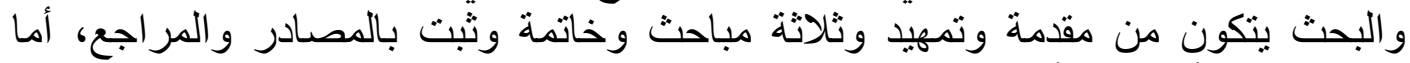

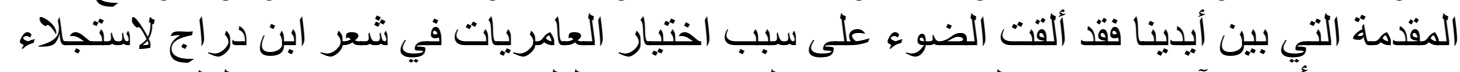

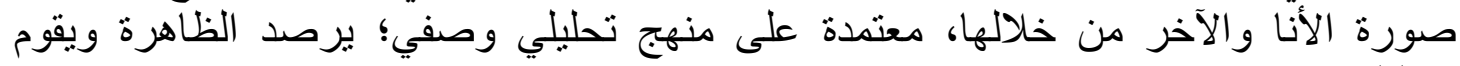

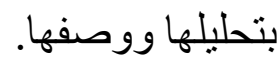

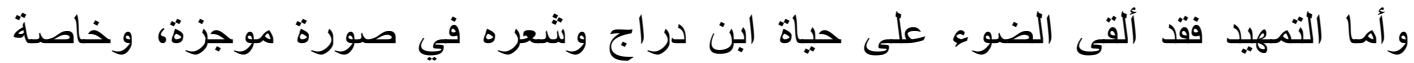

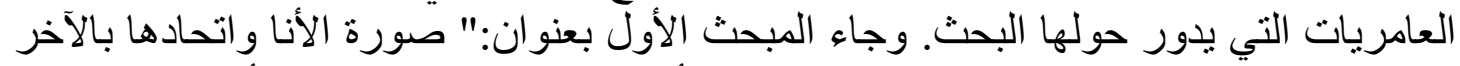

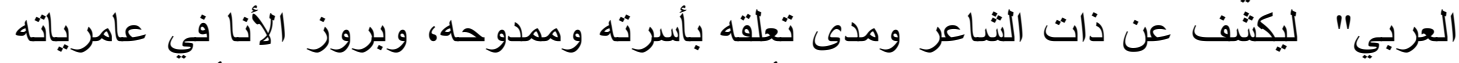

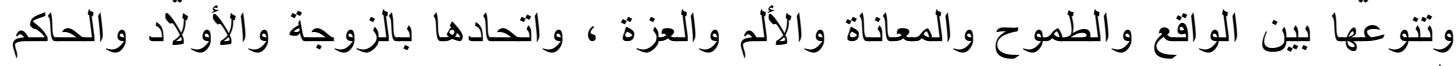

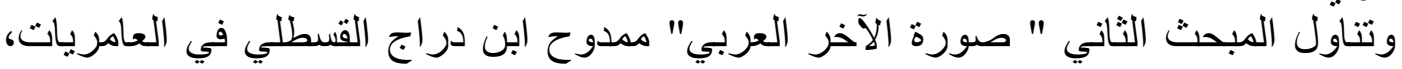

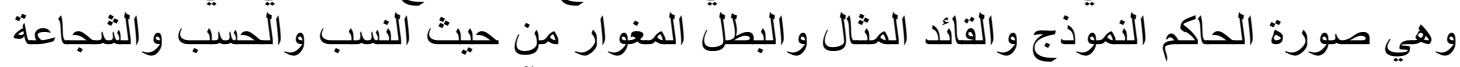

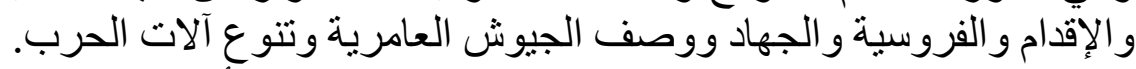

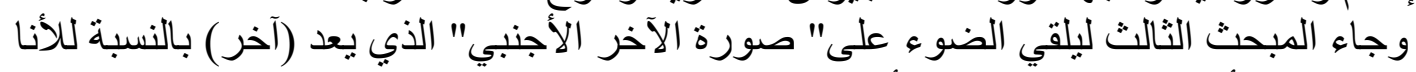

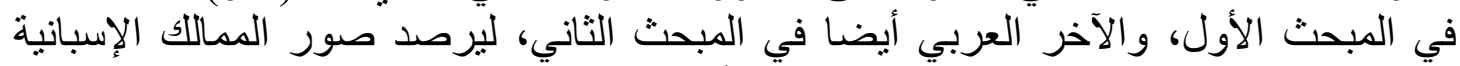
المسيحية وملوكها وقو ادها وسفر ائها في شمال الأندلس. ثم جاءت الخاتمة لترصد أهم النتائج التي توصل التهل إليها البحث، متبوعة بأهم المصادر

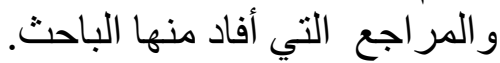

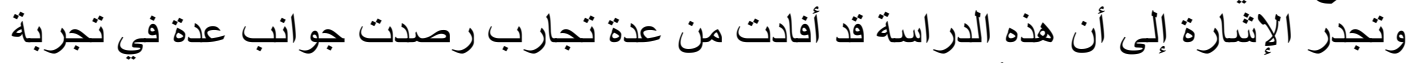

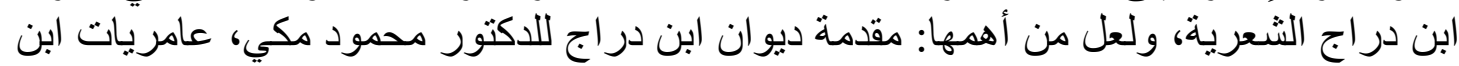

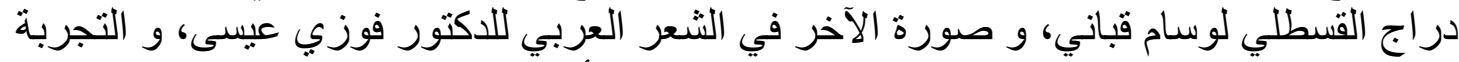

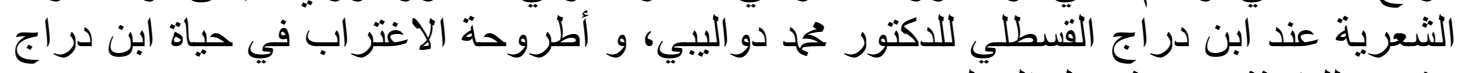

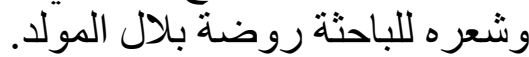
و وأخيرا أرجو أن ينال هذا البحث القبول التول والرضا، فإن تحقق له ذللك فلله الحمد و الثناء ، وإن كانت الأخرى فحسبي أنني اجتهدت و الله المستعان. 


\section{تمهيد}

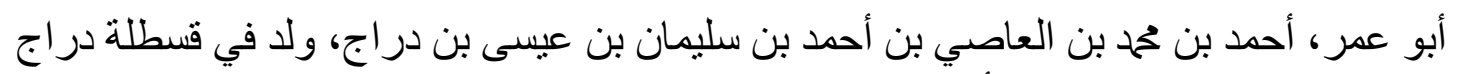

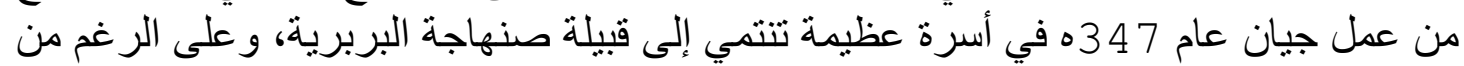

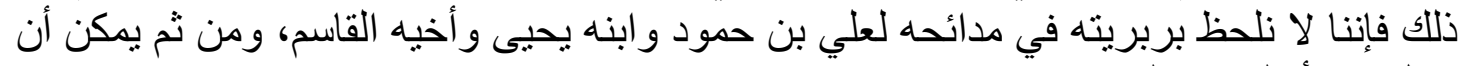

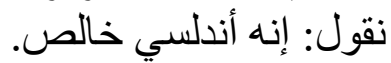

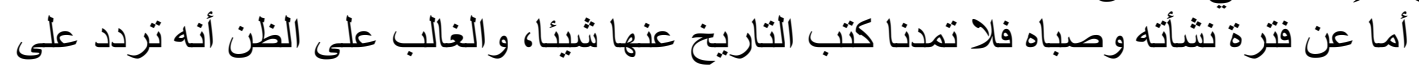

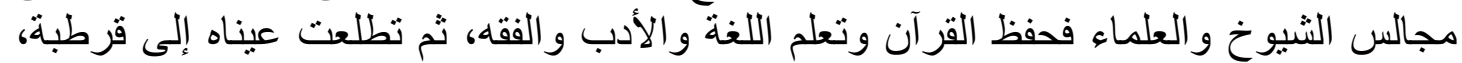

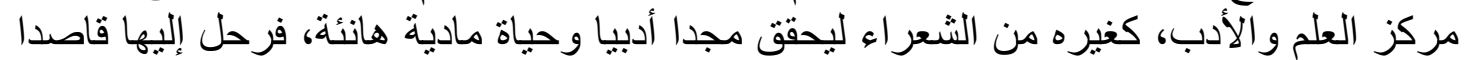

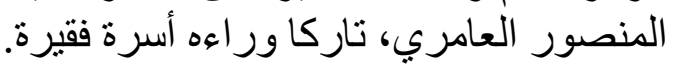

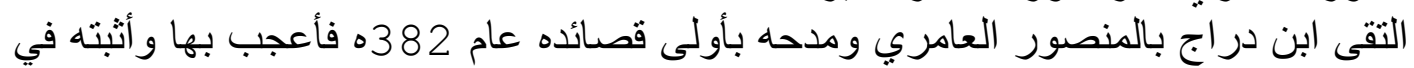

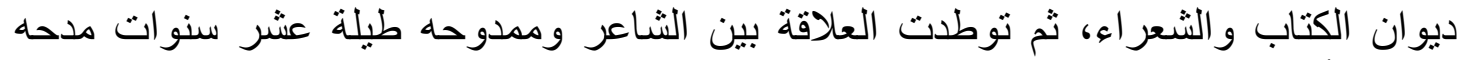

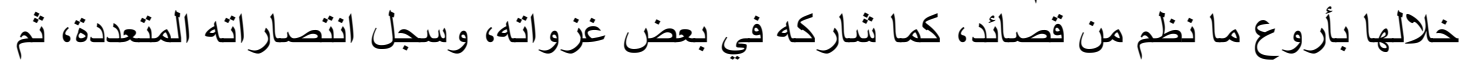

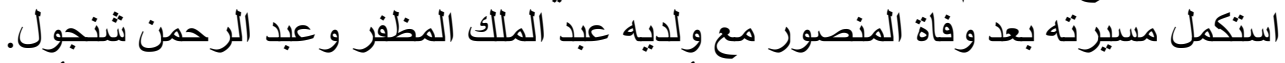

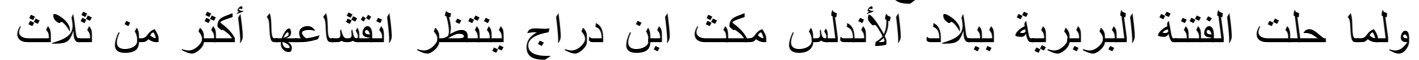

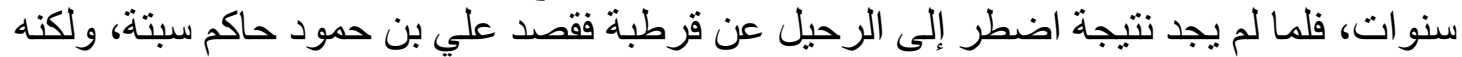
سر عان ما عاد مرة أخرى إلى دويلات العامريين بالأندلس المرية المرية وبلنسية وشاطبة وطرطوشة)

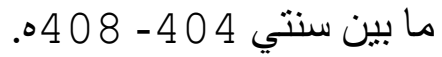

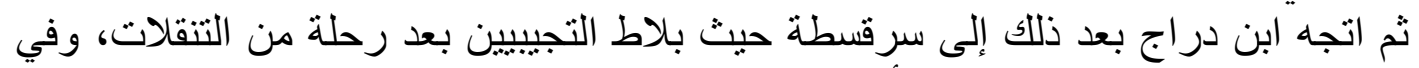

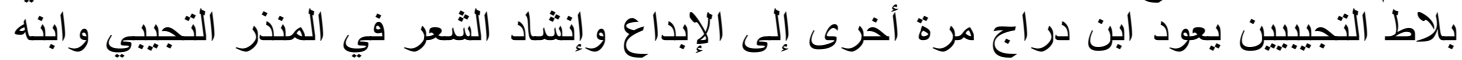

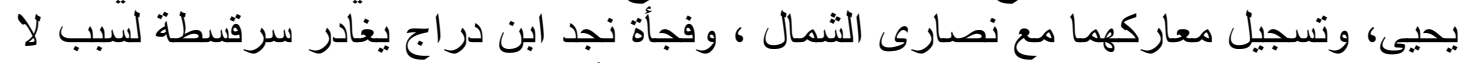

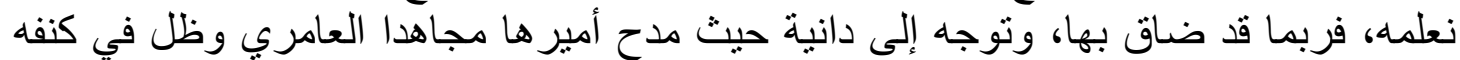

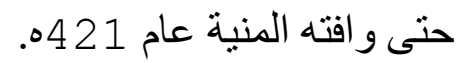

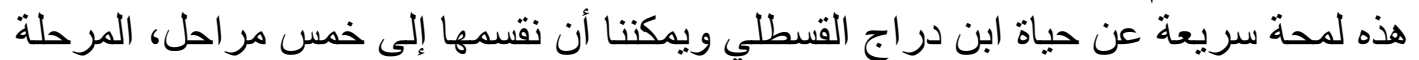

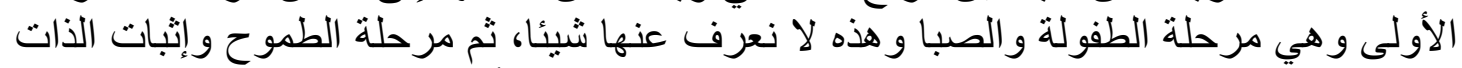

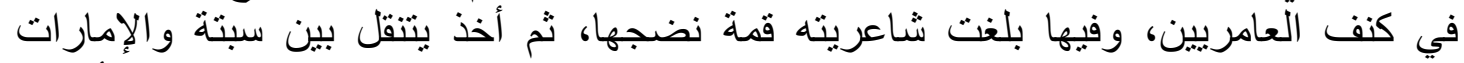

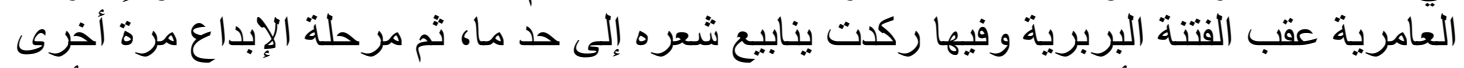

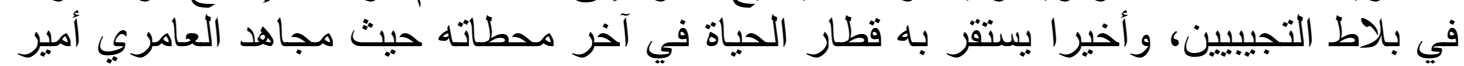

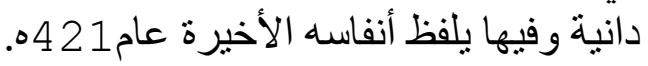

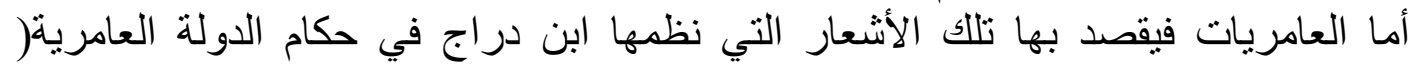

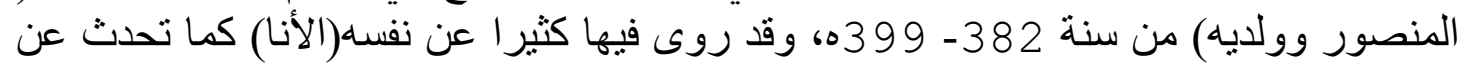

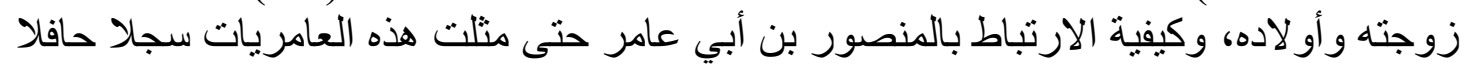

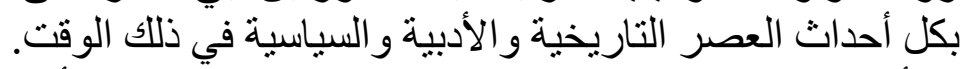

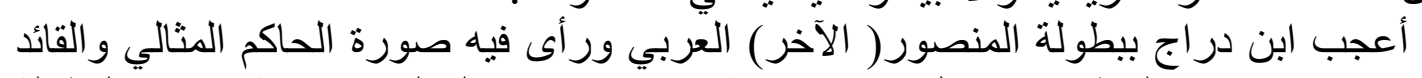
الذي يقدم نفسه فداء لوطنه في سبيل انتشار رقعة الإسلام، فرصد لنا لنال لوحات حية تنبض بالبطولة النئ 


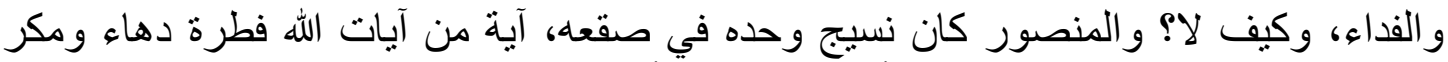

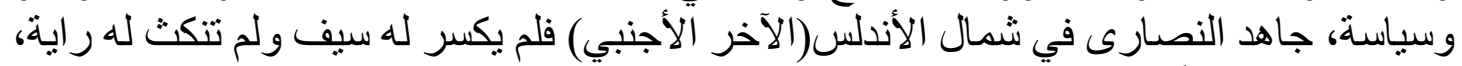

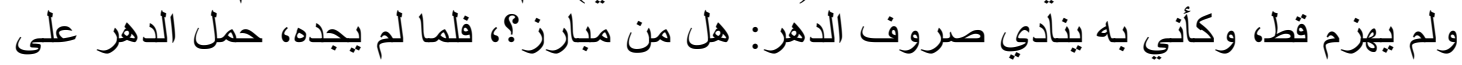
حكمه فانقاد له وساعده.

\section{المبحث الأول صورة الأنا واتحادها بالآخر العربي}

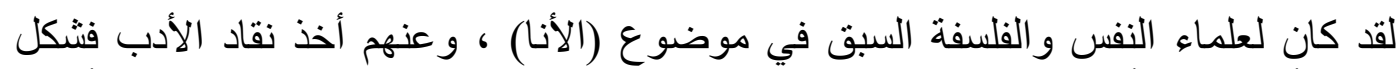

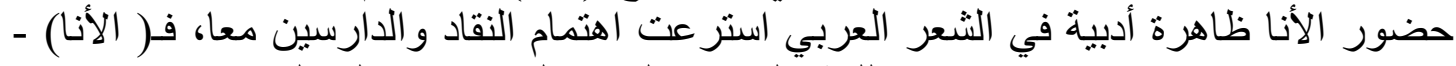

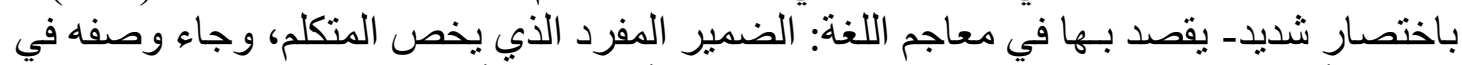

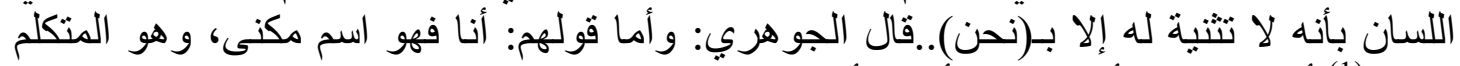

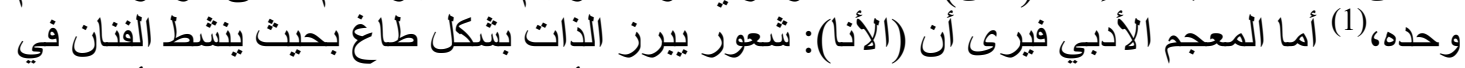

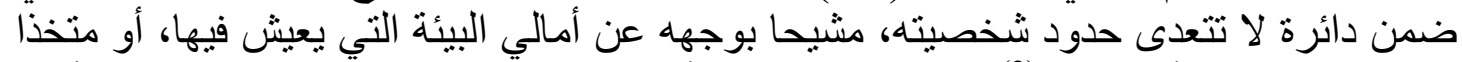

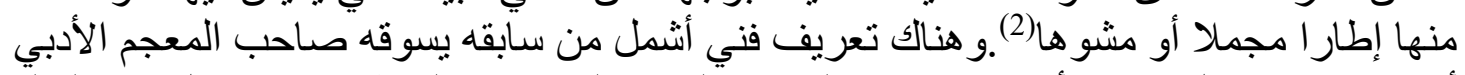

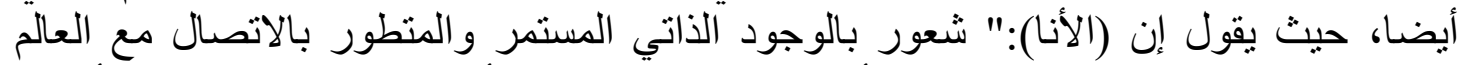

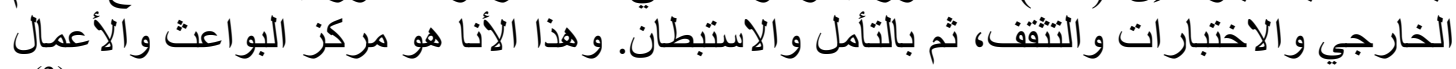

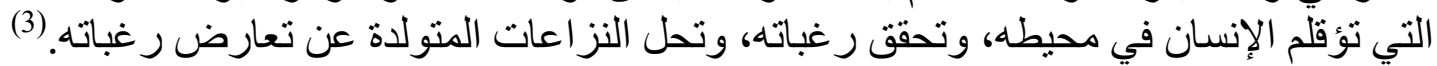

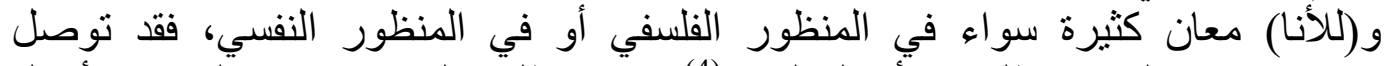

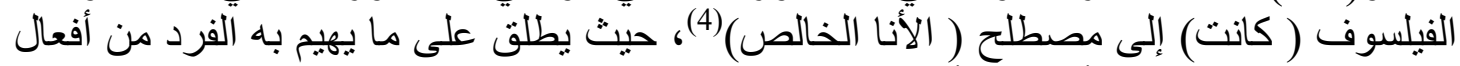

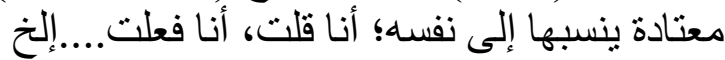

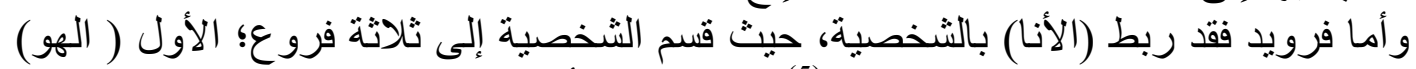

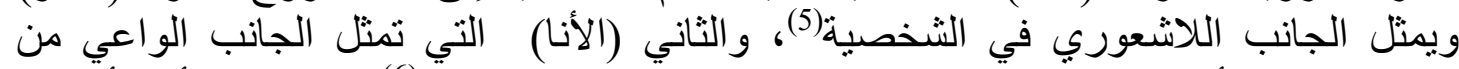

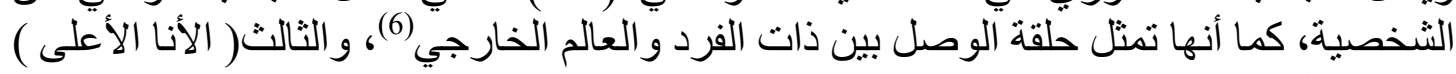

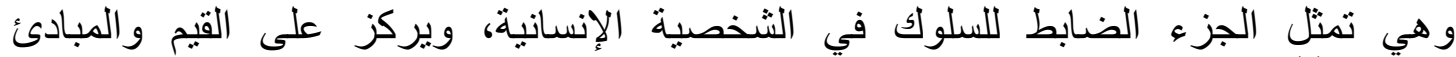

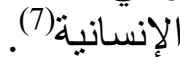

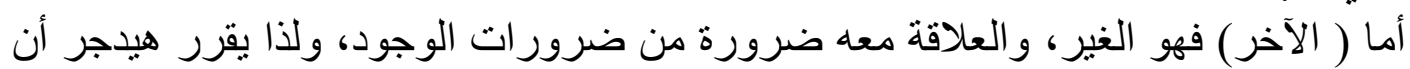

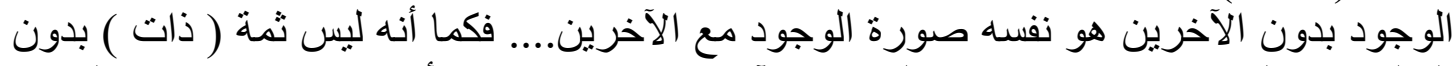

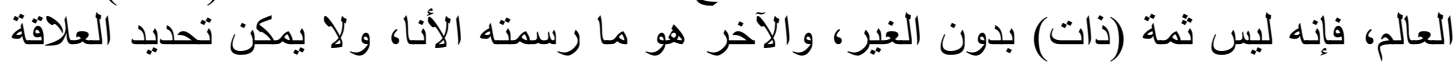

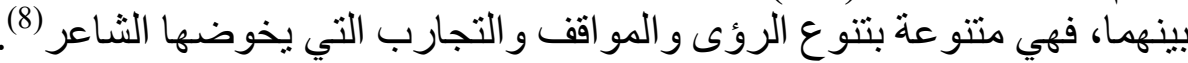

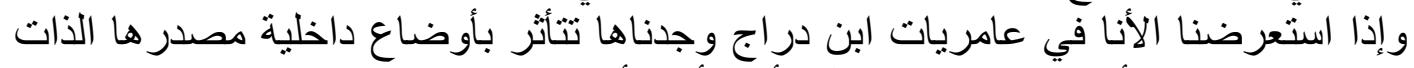

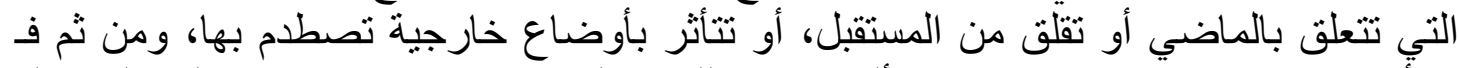

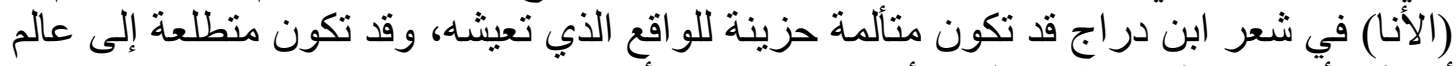
أفضل وأرحب، ولديها طموح لمجد أدبي وحياة مادية أحسن من و واقعها. 
و المتأمل في شعر ابن دراج القسطلي وخاصة عامرياته يجد صورة الأنا واضحة وقد الأد

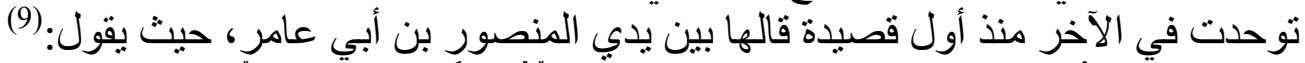

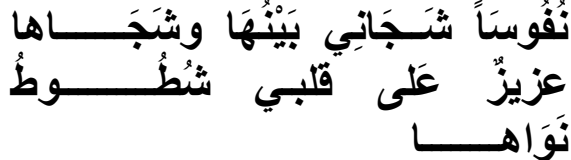

علَى

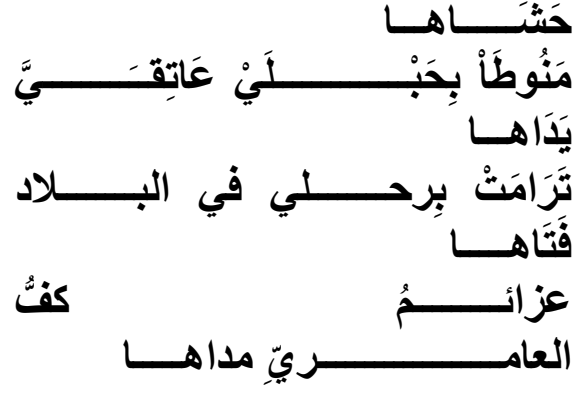

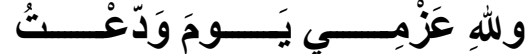
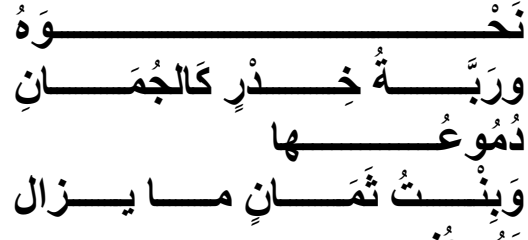

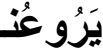

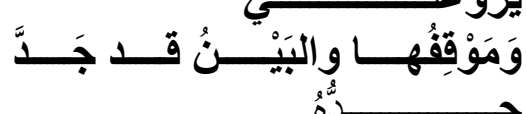

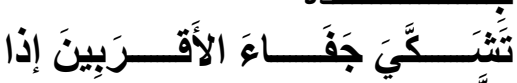

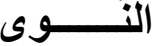

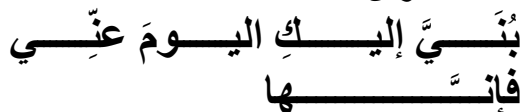

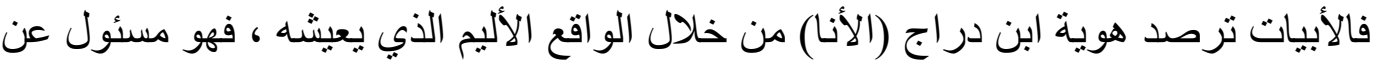

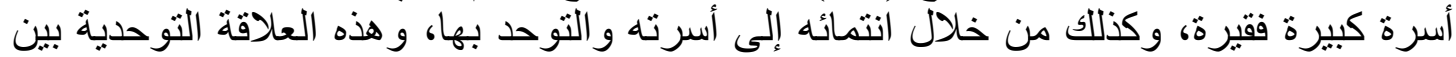

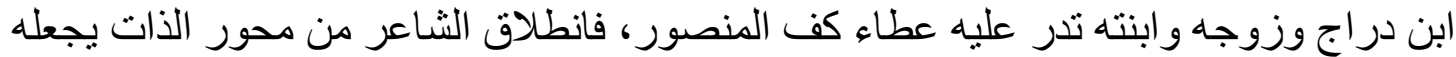

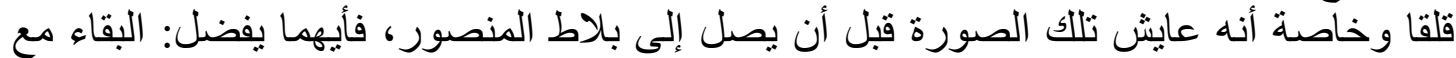

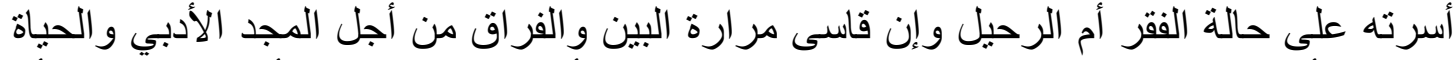

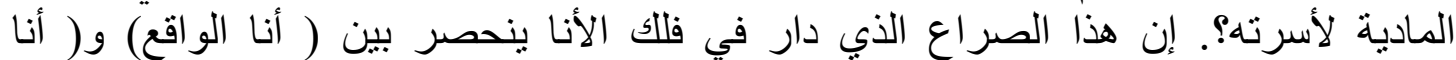

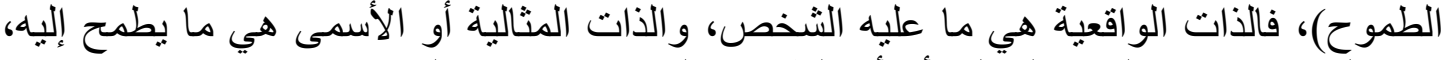

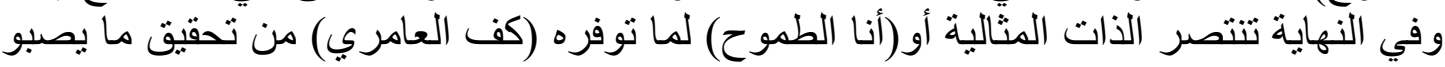
إليه الثاعر.

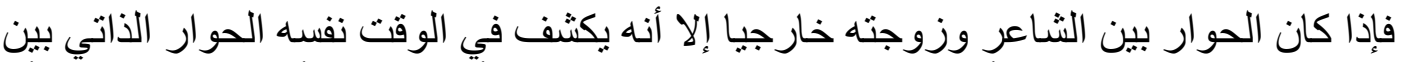

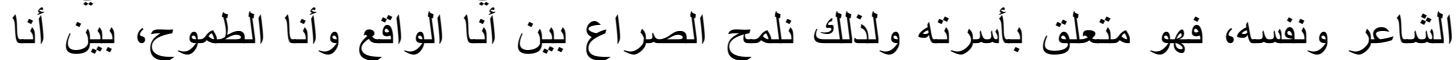

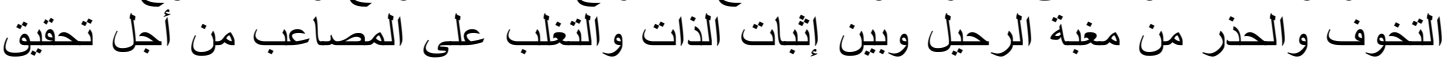
الأهداف و الغايات.

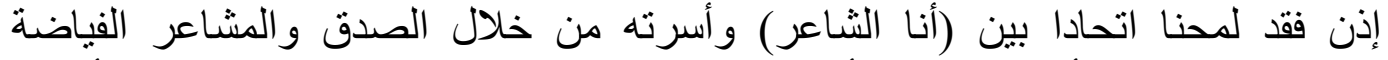

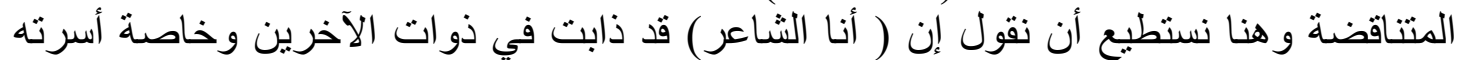

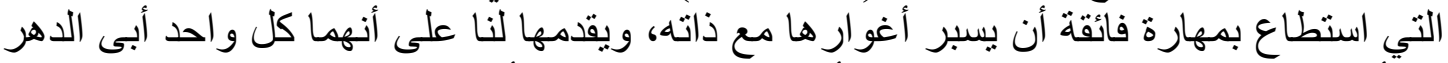

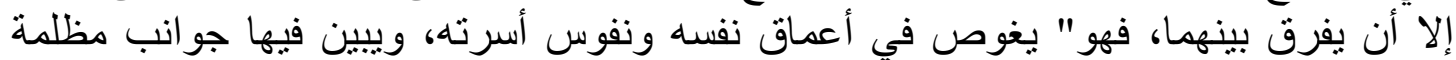

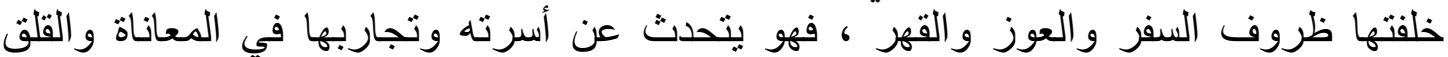

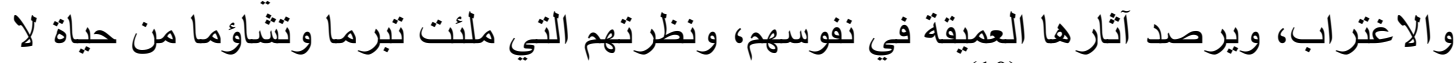

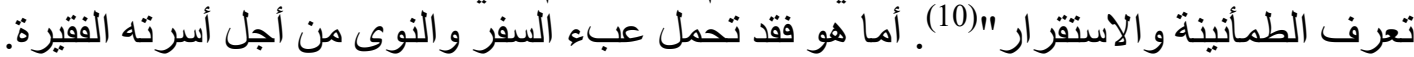

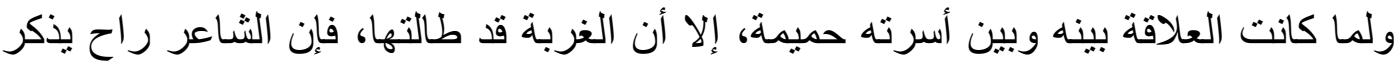
ذللك، ويرصد لحظة الوداع في عاطفة مكلومة، نحس خلالها بذات الثاعر أو (أنا) الألم

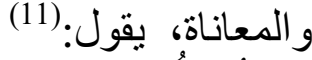

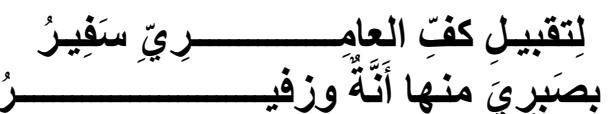

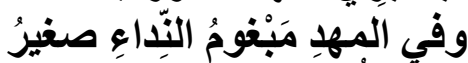

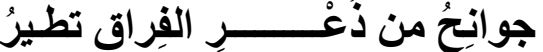

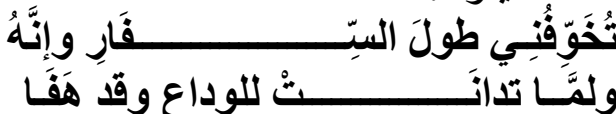

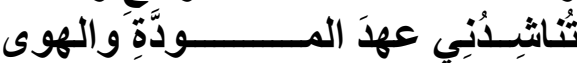

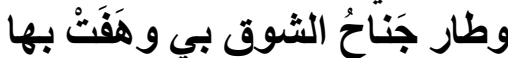

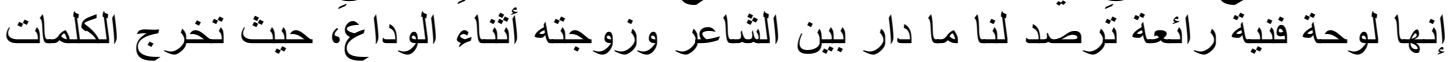

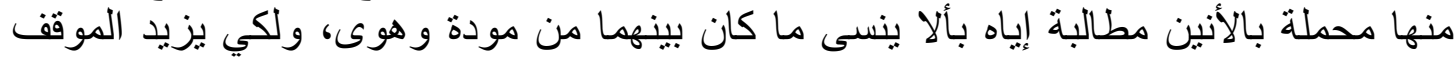


تأثير ا في المشاهد يجعل معها في هذا المشهد أصغر أبنائهما، وهنا يتأزم الموقف، فهذا العنصر

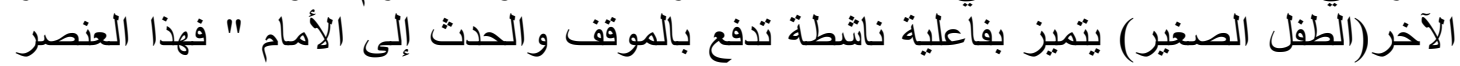

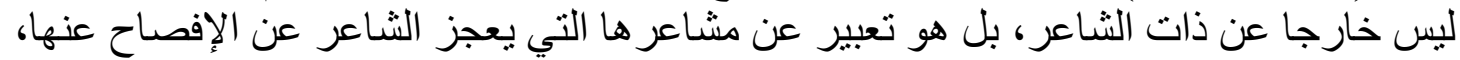

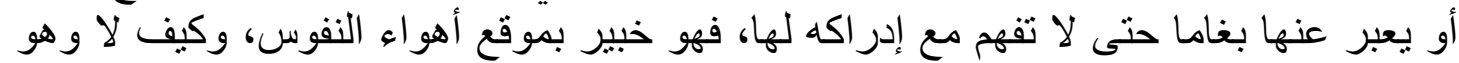

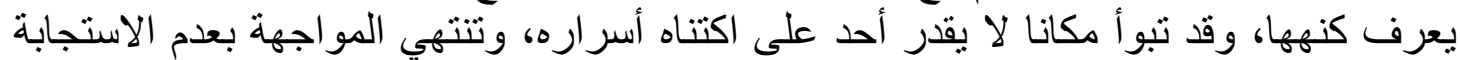

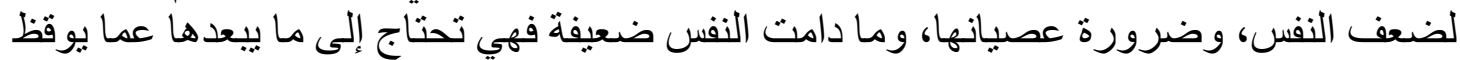

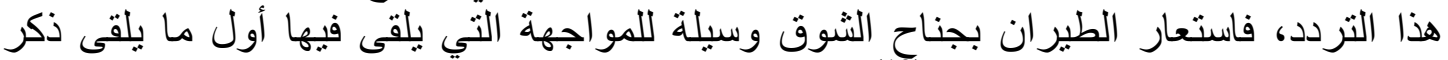

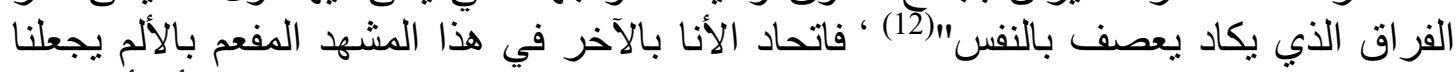

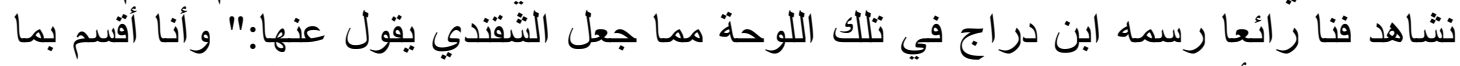

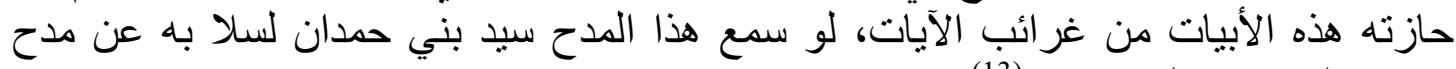

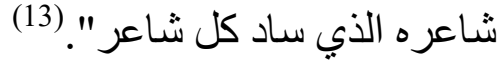

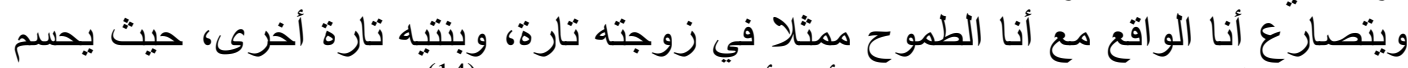

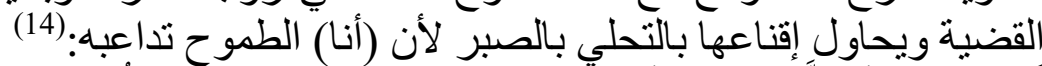

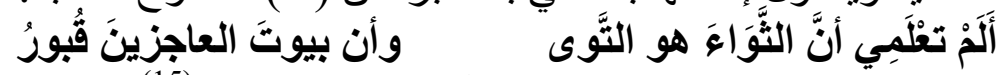

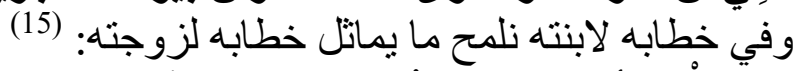

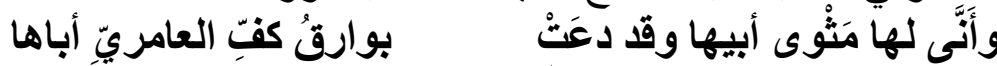

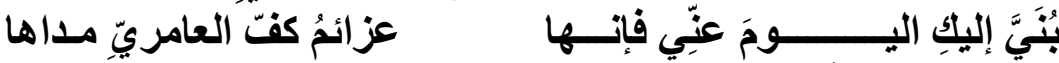

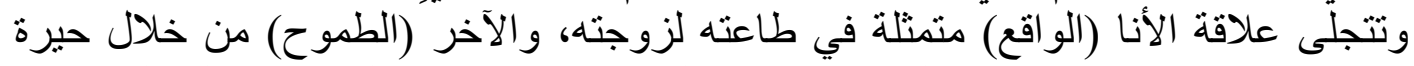

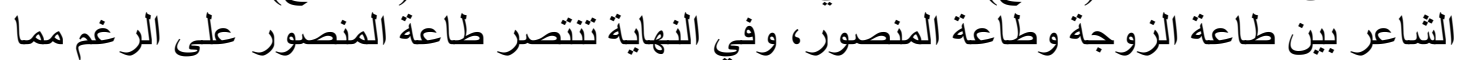

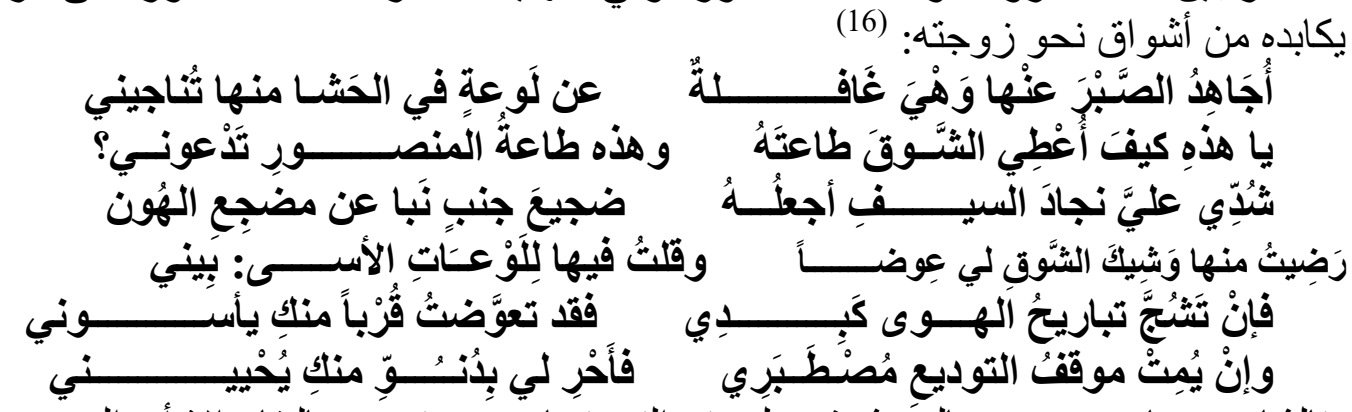

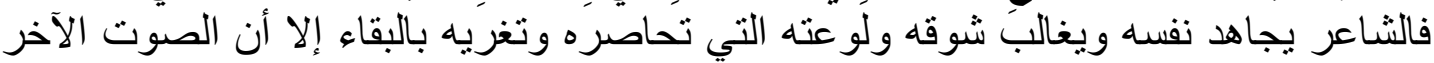

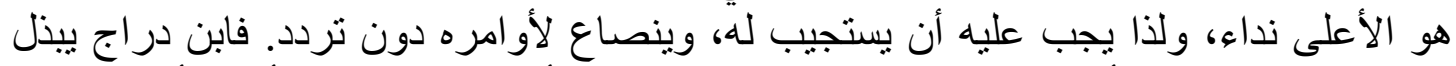

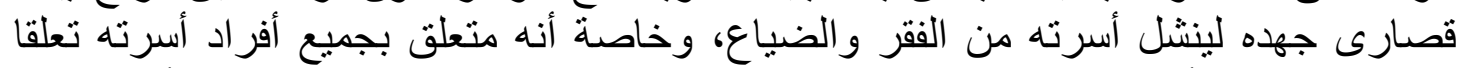

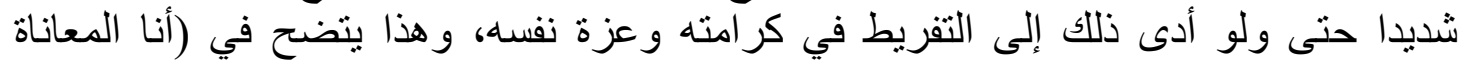

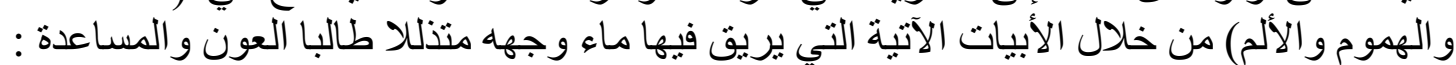

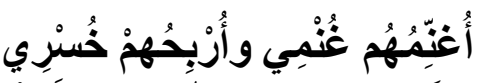

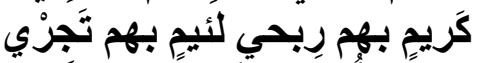

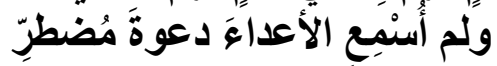

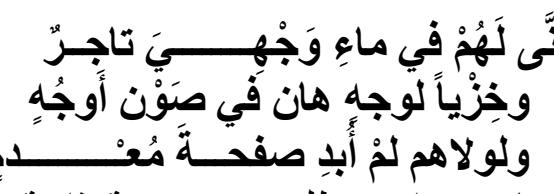

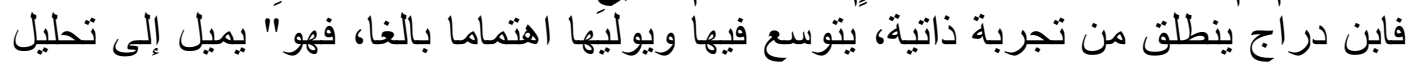

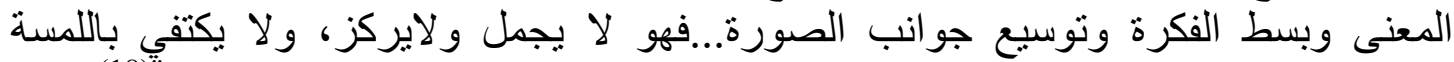

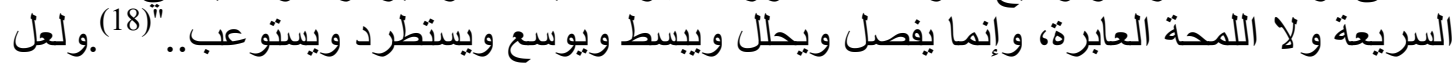

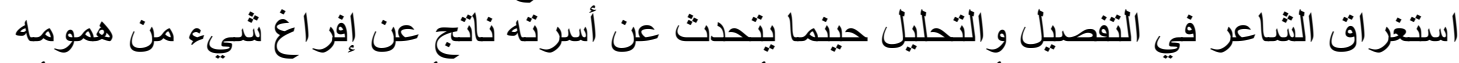

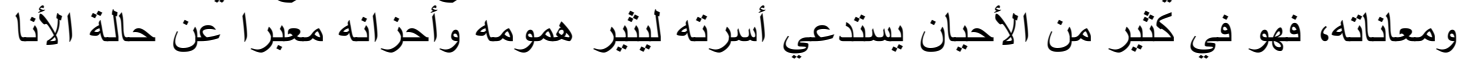

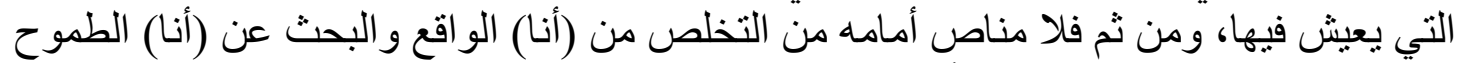

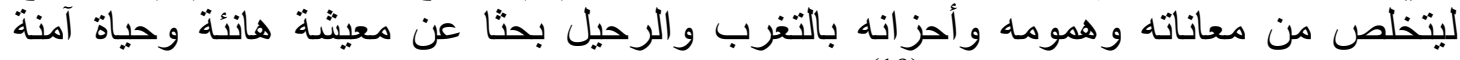
مستقرة، حيث يقول مخاطباز زوجته:(19) 


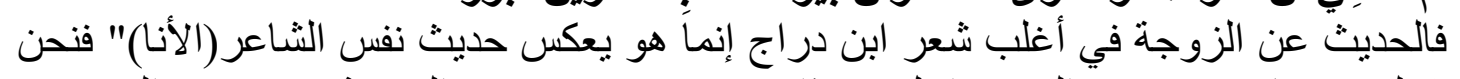

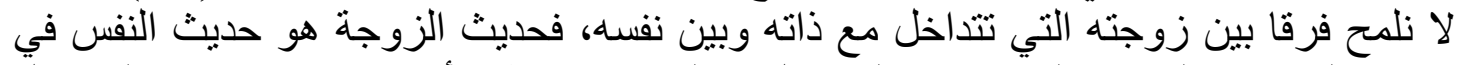

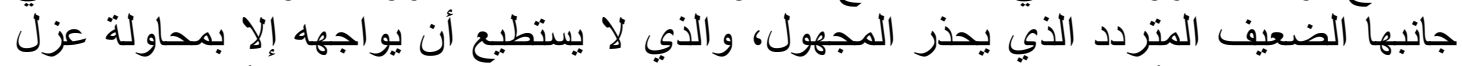

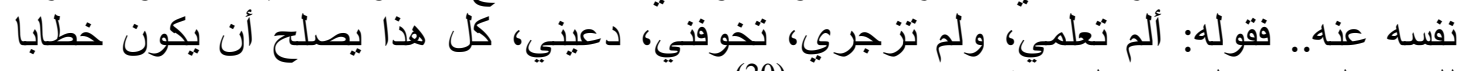

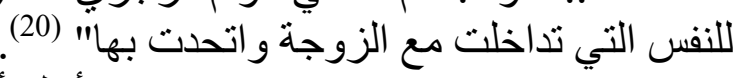

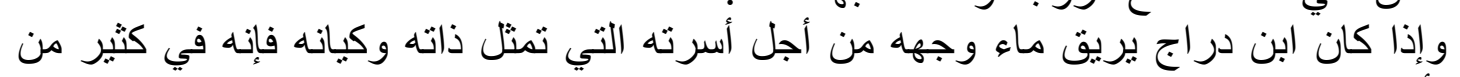

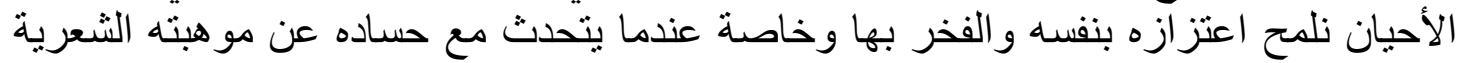

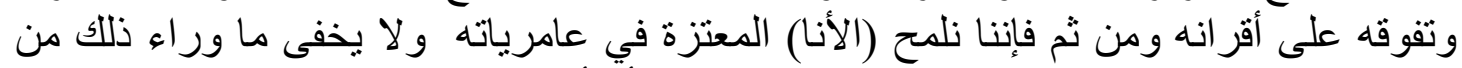

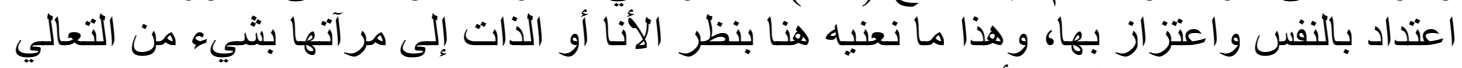

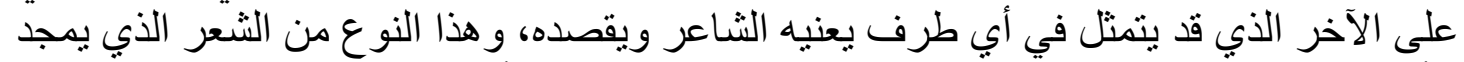

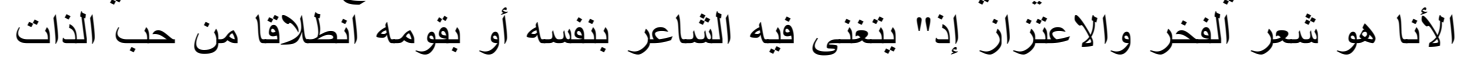

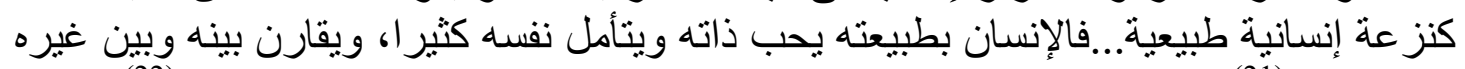

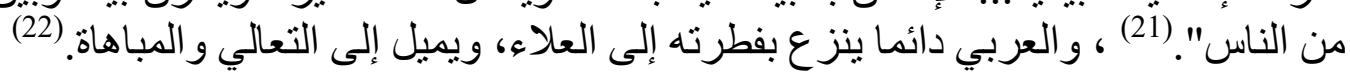

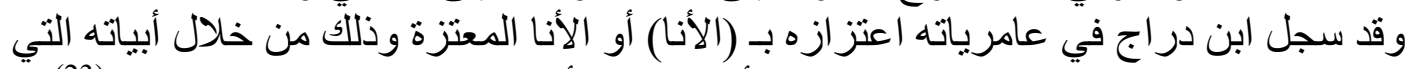

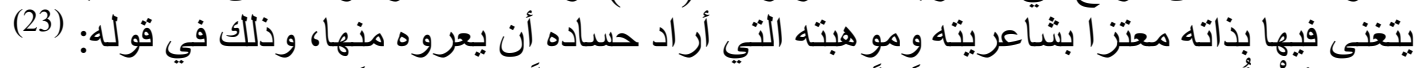

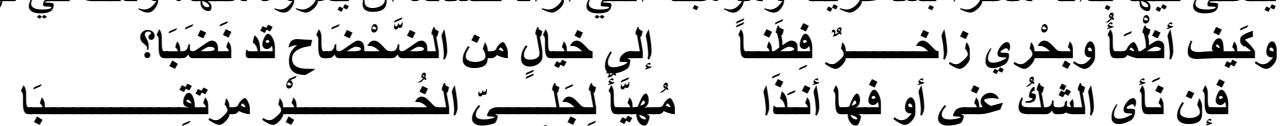

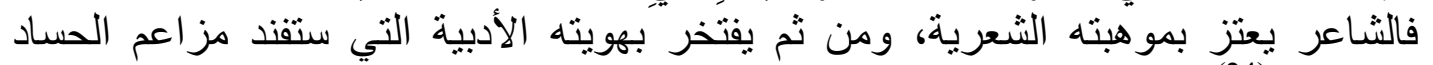

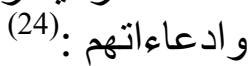

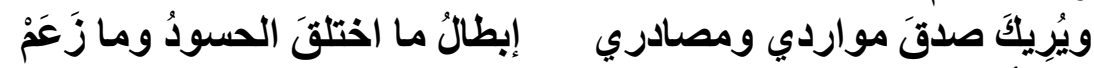

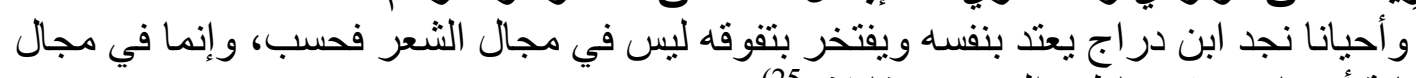

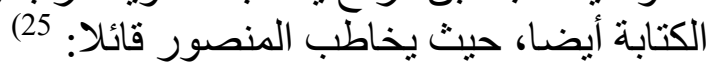

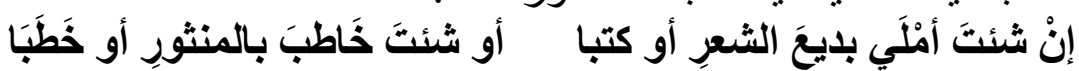

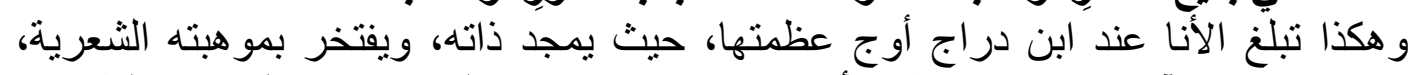

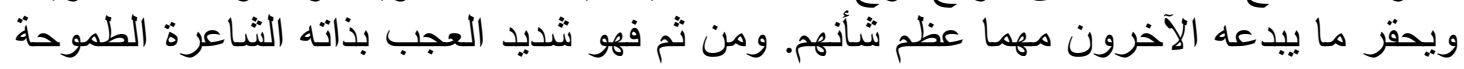

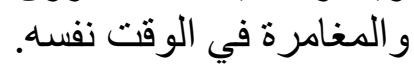

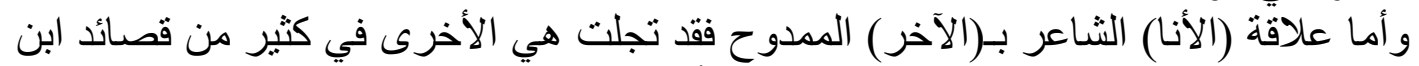

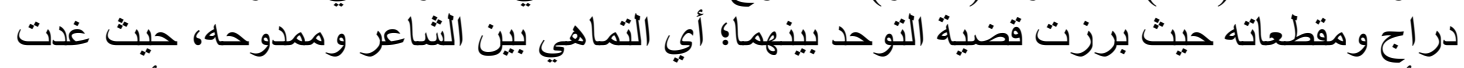

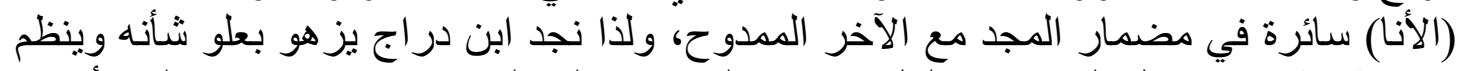

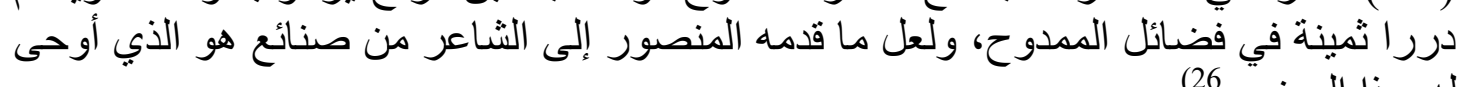
له بهذا المعنى:

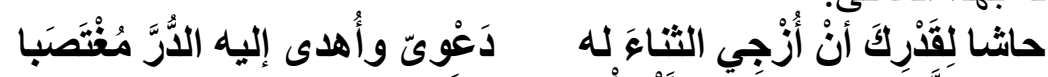

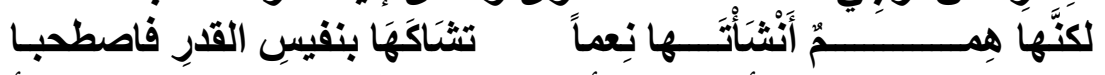

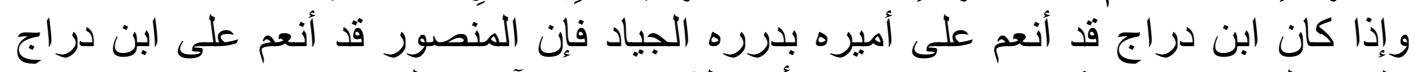

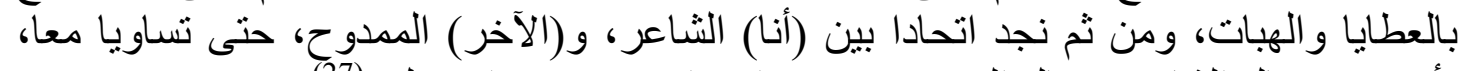

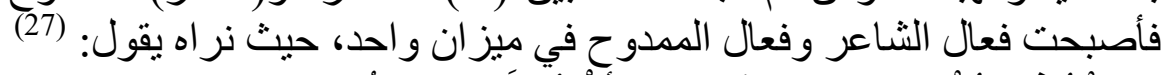

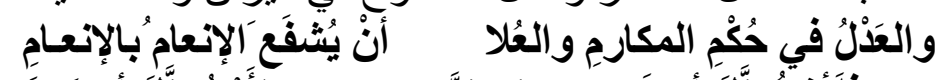

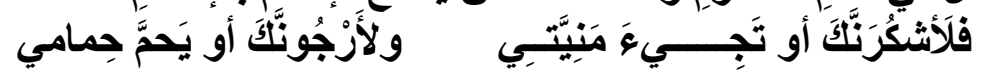


ولما كان ابن دراج أمير ا في القريض والإقدام وحب المغامرة فإن المنصور أمير في البطولة

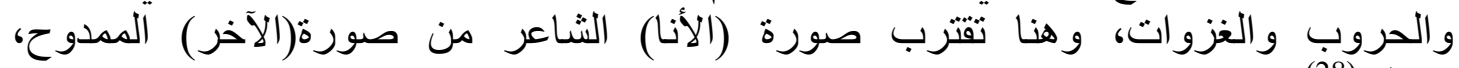
فيقول: (28)

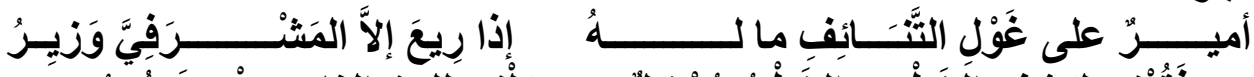

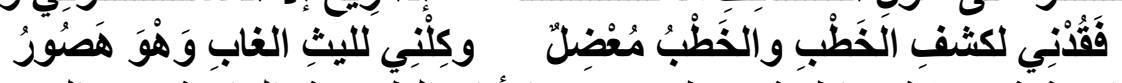

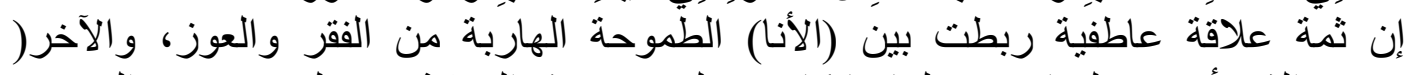

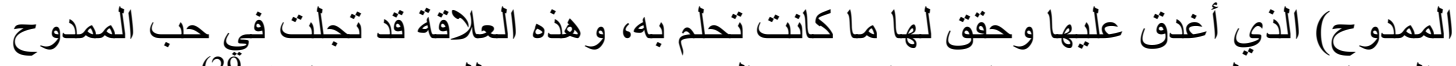

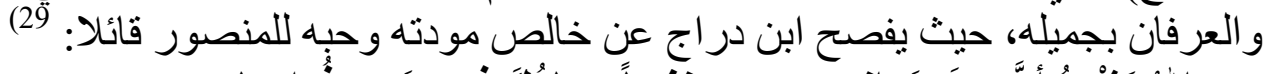

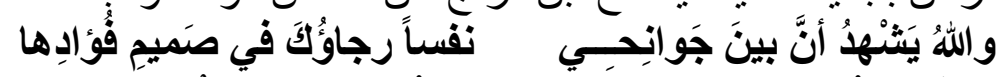

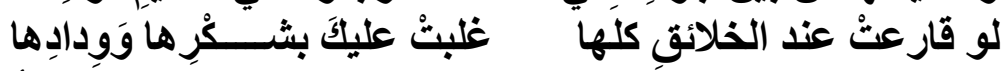

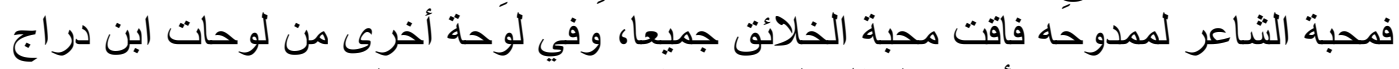

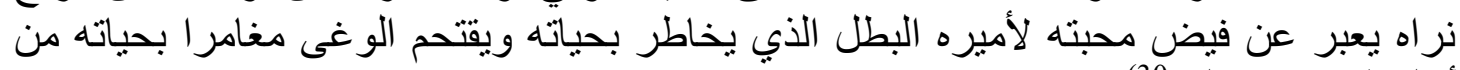

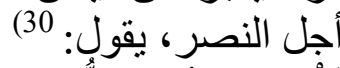

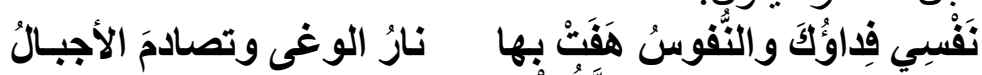

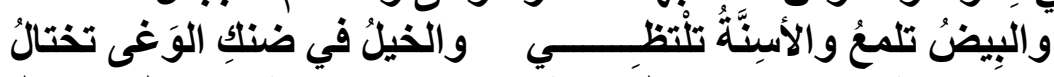

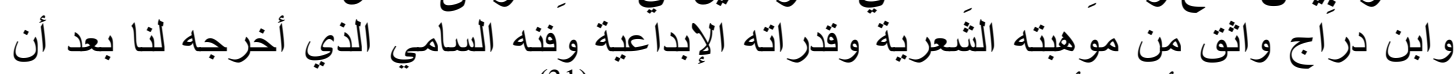

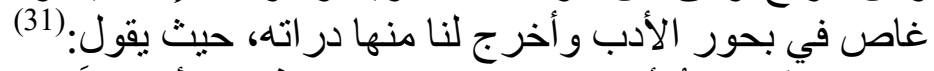

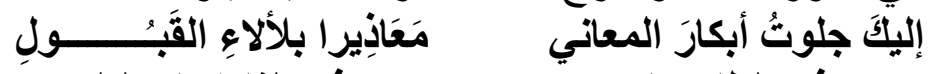

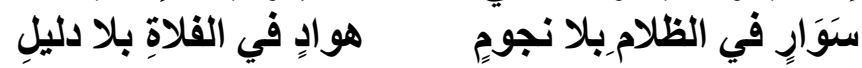

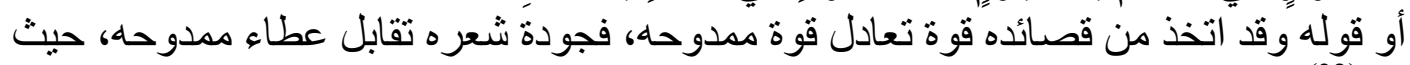

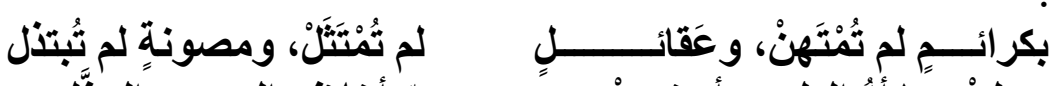

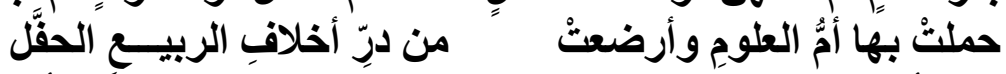

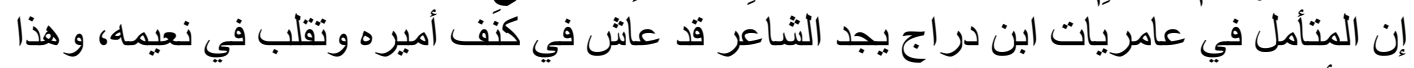

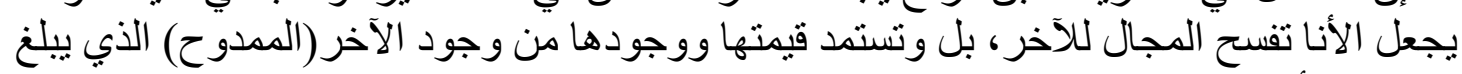

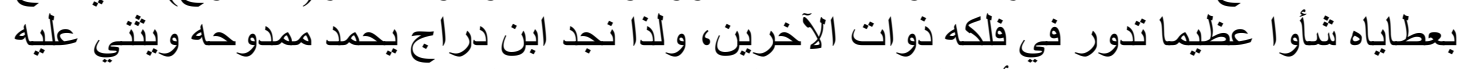

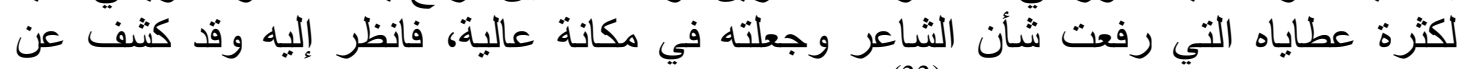

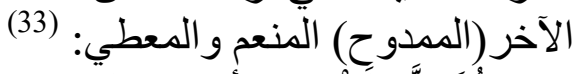

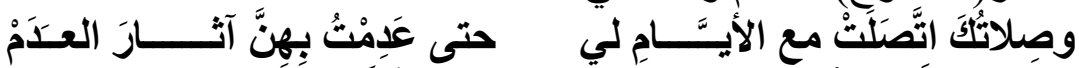

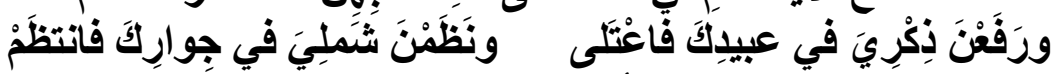

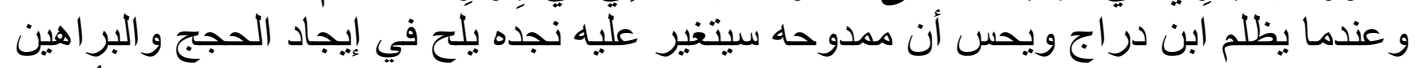

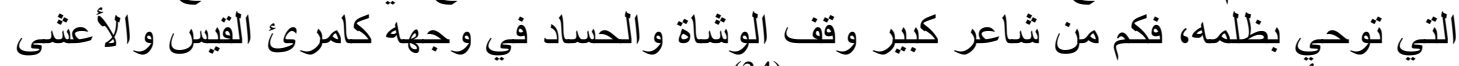

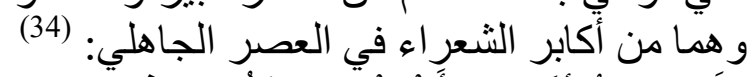

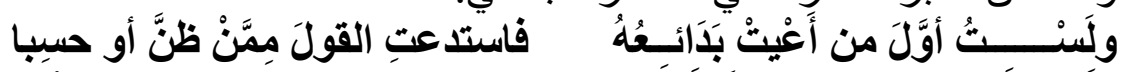

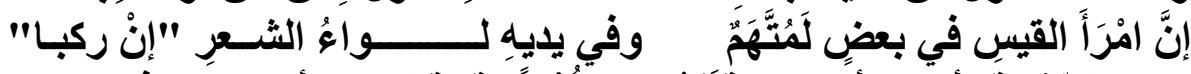

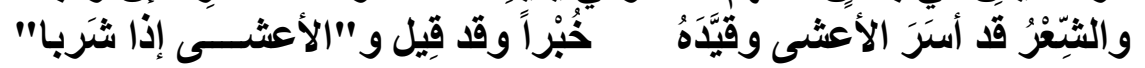

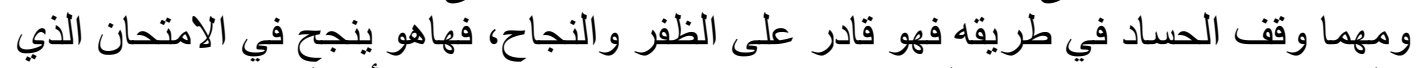

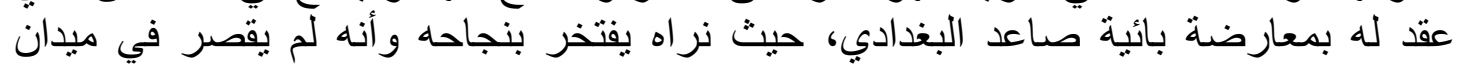

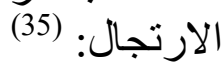

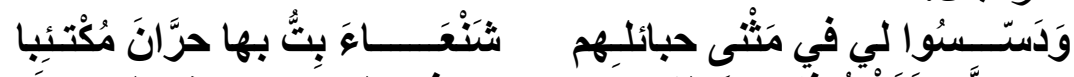

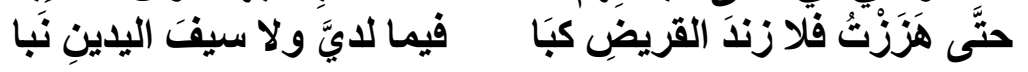


ومع وجود الآخر (الحاسد) الذي أثشار إليه ابن دراج في الأبيات السابقة نجده يتمكن في بلاط

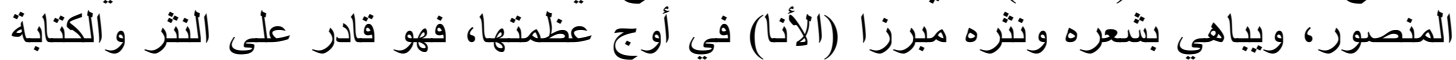

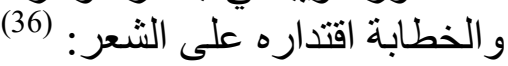

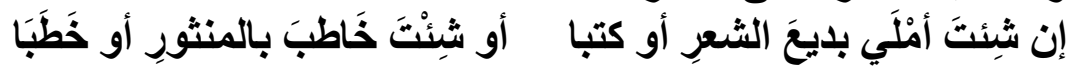

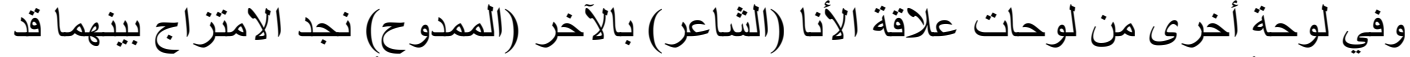

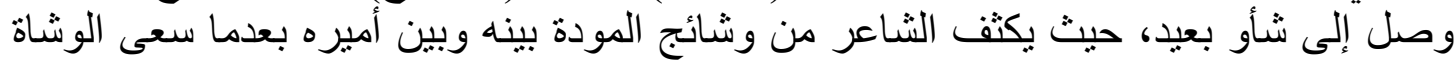

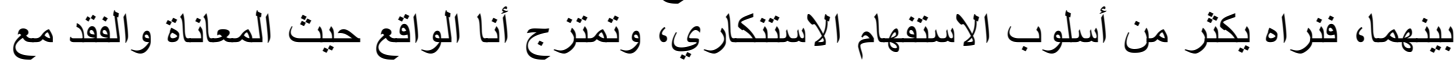

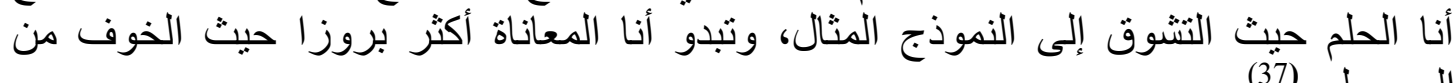

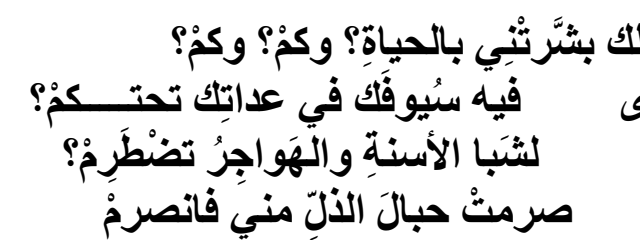

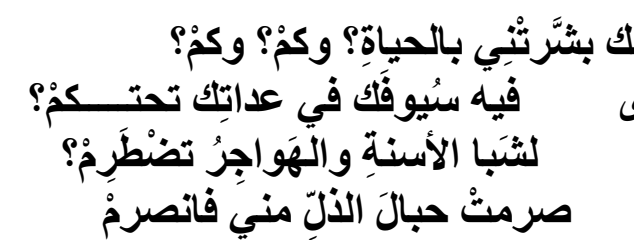

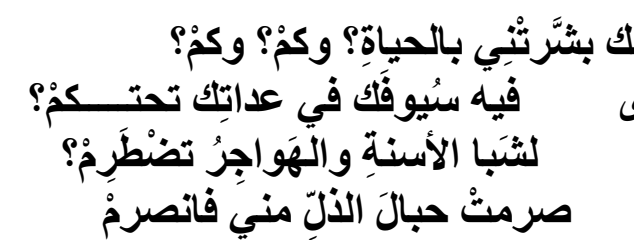

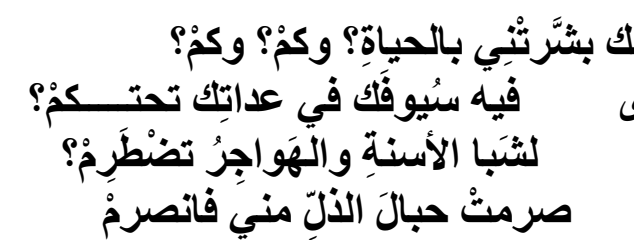

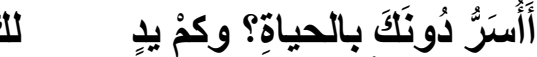

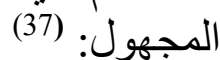

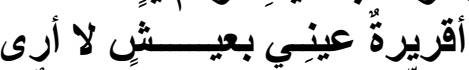

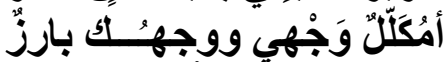

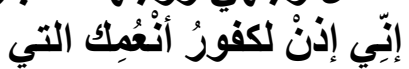

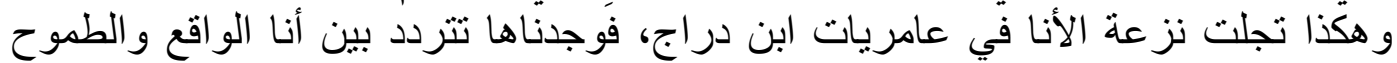

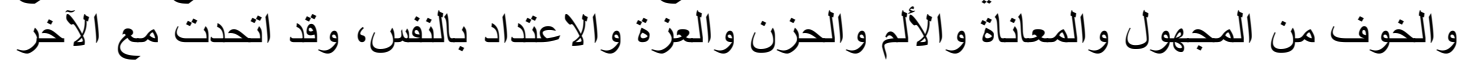
الذي تنوع بتنوع الموقف و الرؤية، فكانت أسرته تارة وحساده تارة أخرى وممدو حها تارة الثالثالثة.

\section{صورة الآخر العربي (عي كمي}

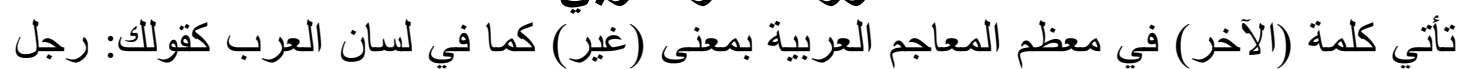

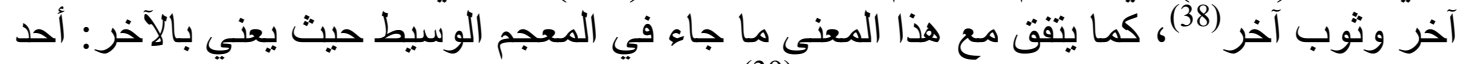

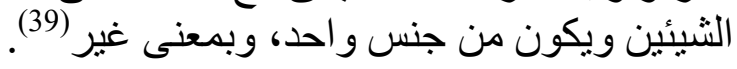

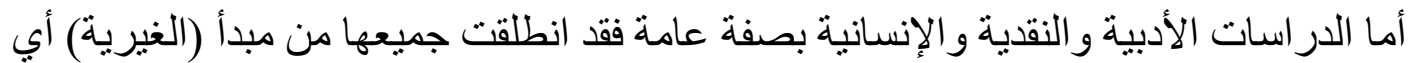

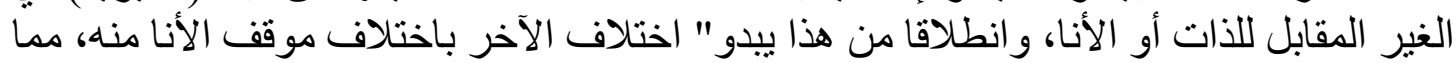

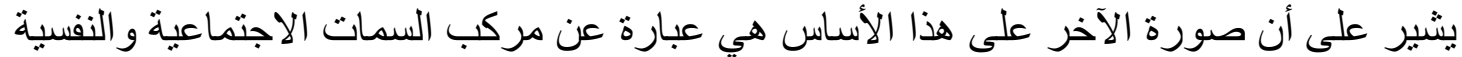

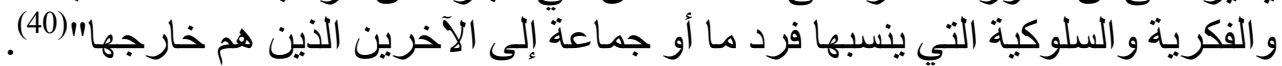


وتتمثل صورة الآخر في هذا المبحث في الحاكم الذي يرمز للقوة والإرادة الصلبة والعقبدة

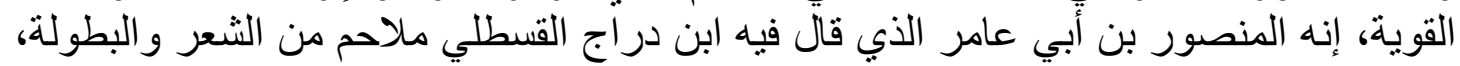

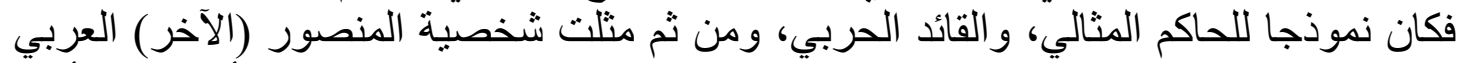

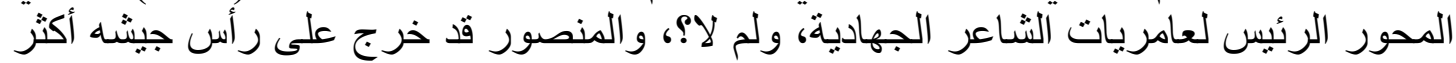

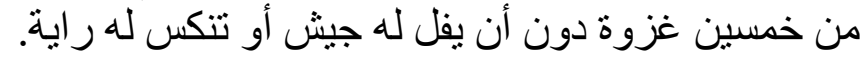

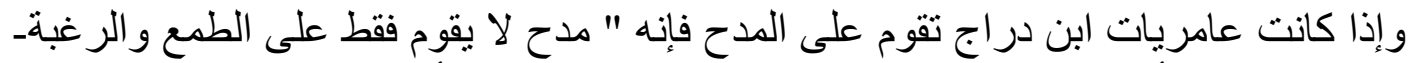

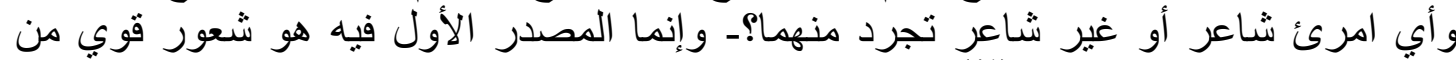

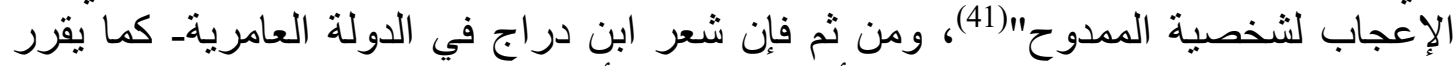

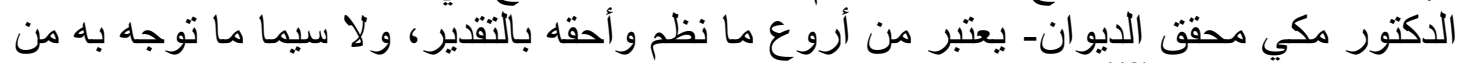

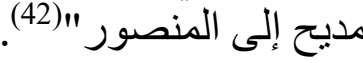
و ابن در اج الذي مدح المنصور بن أبي عامر بأكثر من ثلاثثين قصبدة ليكثف في هذه القصائد صورة الحاكم النموذج والقائد البطل الذي حاز أعلى درجات القوة والعظمة، فمن حيث النسب

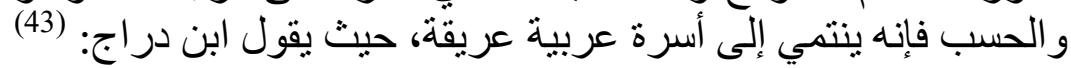

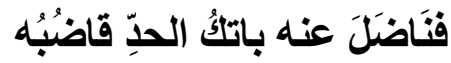

توسنََّ فَي الأحسـابِ سَتْلََ ذُرَاها

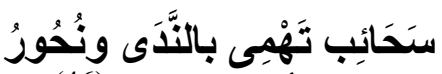

تخِيَّرهُ الرََّحمنُ من سَرْوِ حِمْنَرِ

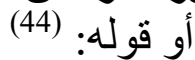

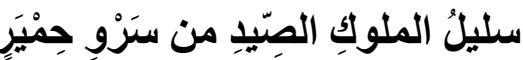

أو قوله: (45)

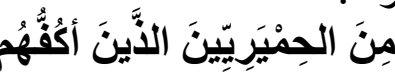

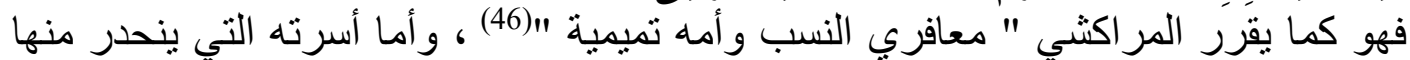

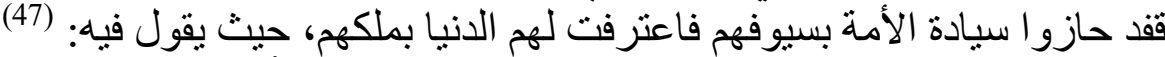

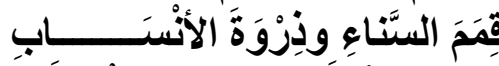

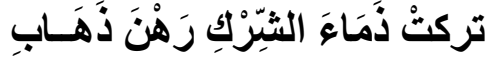

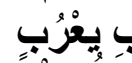

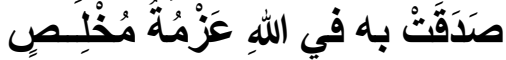

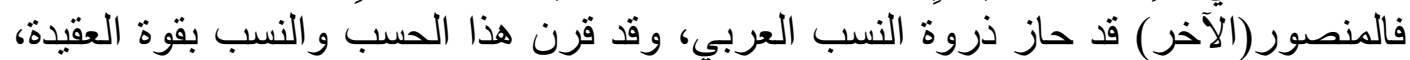

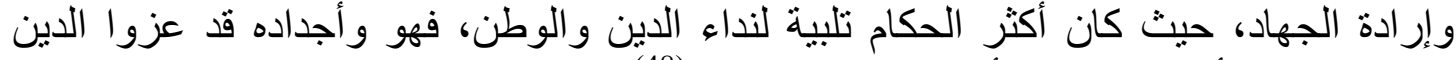

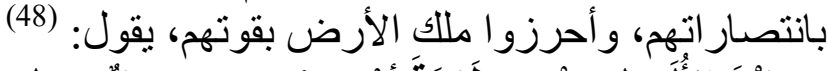

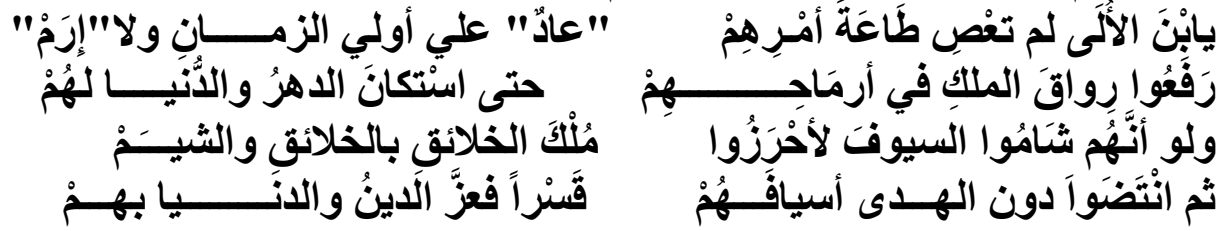

ولما كان المنصور سياسيا بار عاوقائدا عسكريا فذا، فقد راح ابن در اج يثبيد به ويفخر بقوته

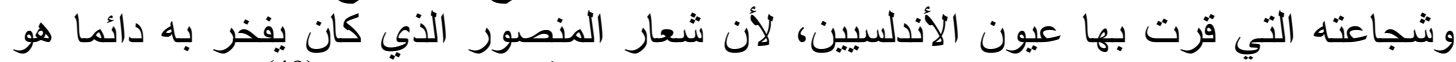

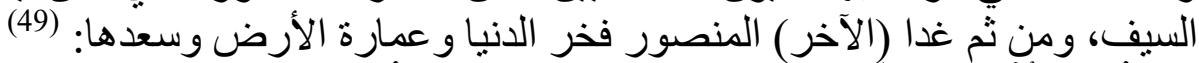

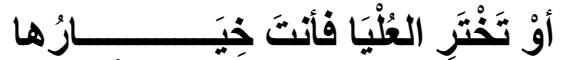

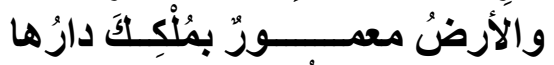

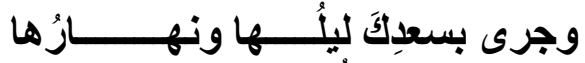

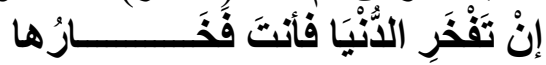

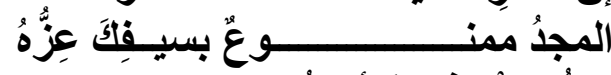

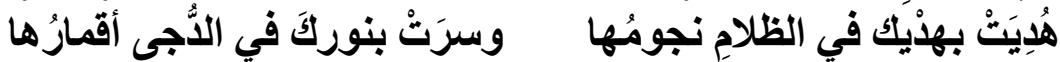

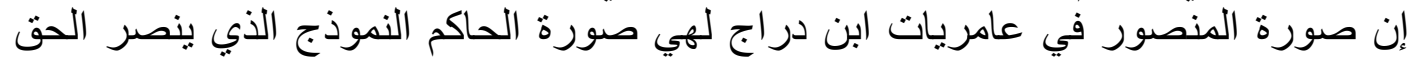

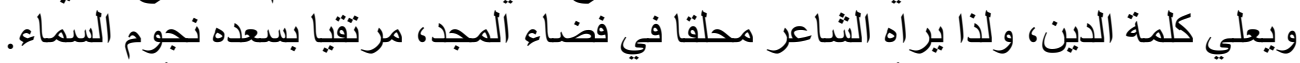

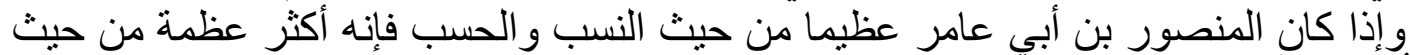

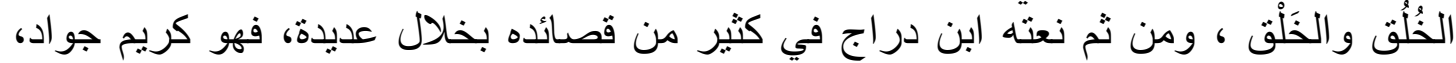

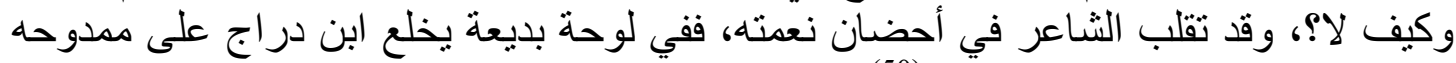

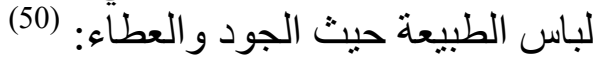




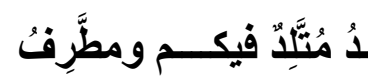

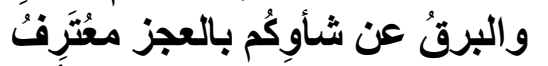

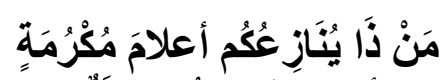

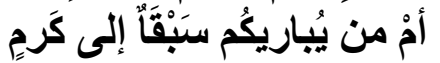

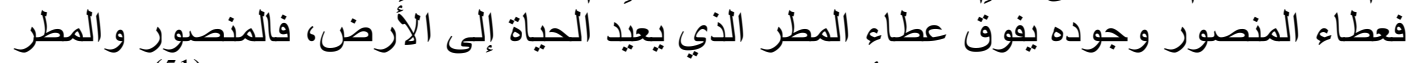

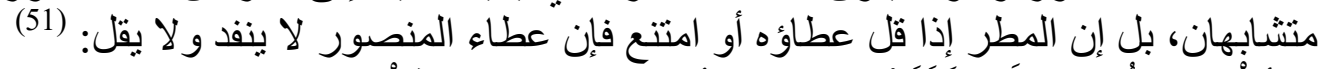

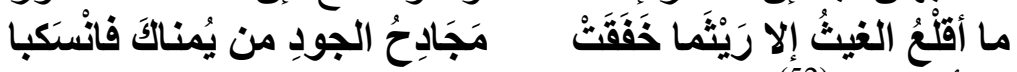

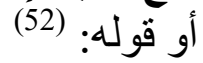

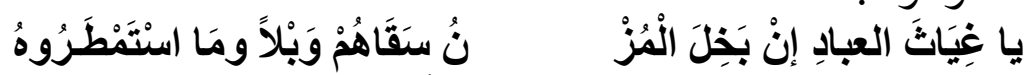

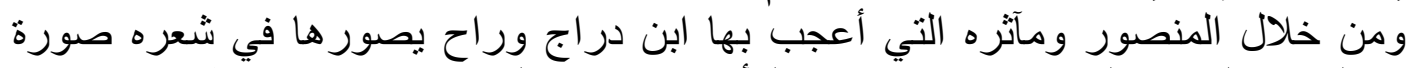

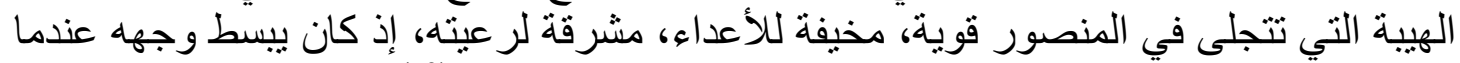

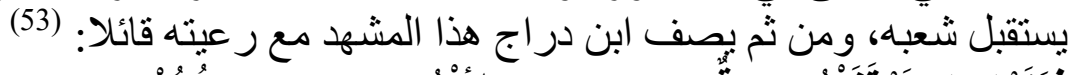

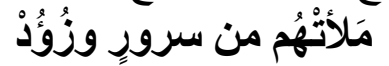

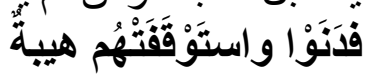

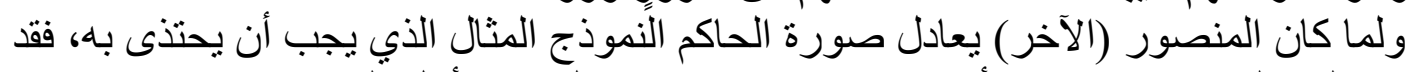

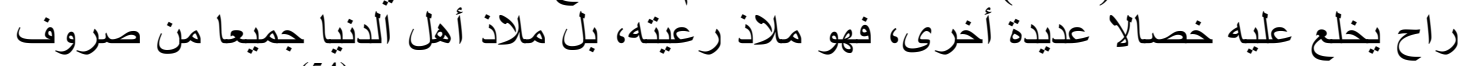

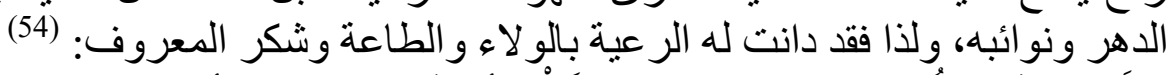

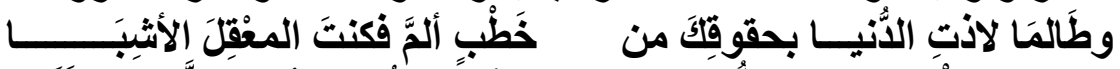

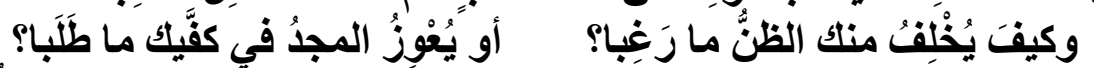

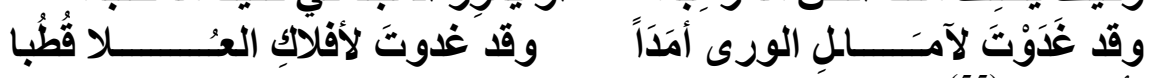

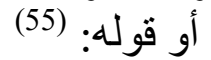

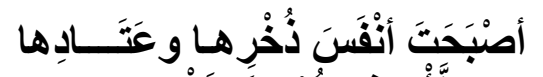

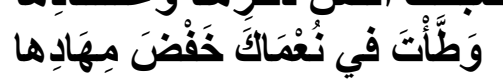

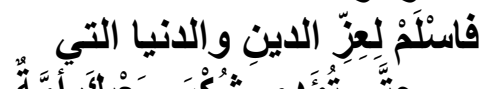

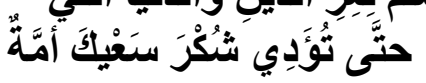

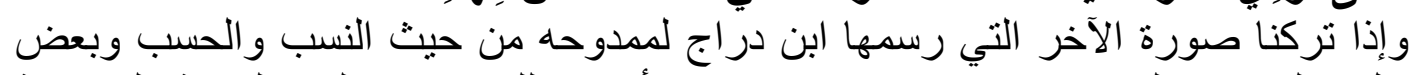

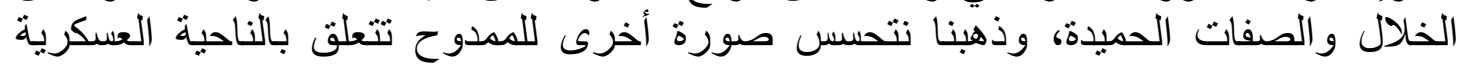

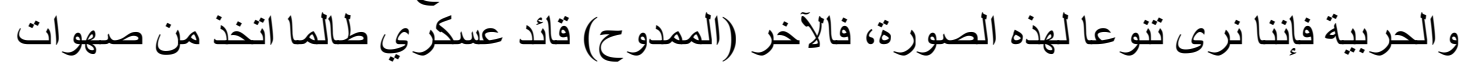

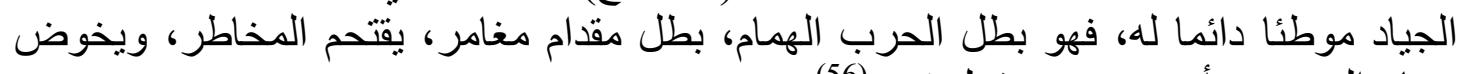

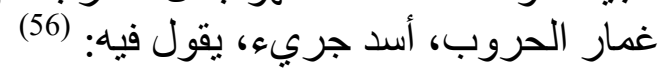

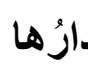

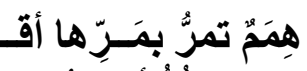

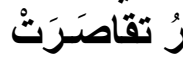

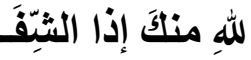

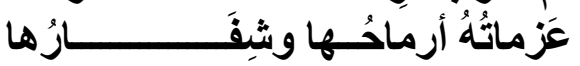

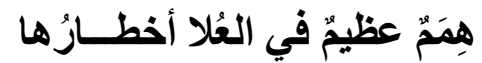

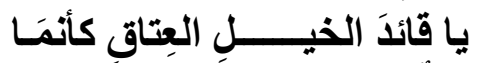

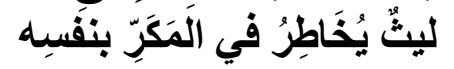

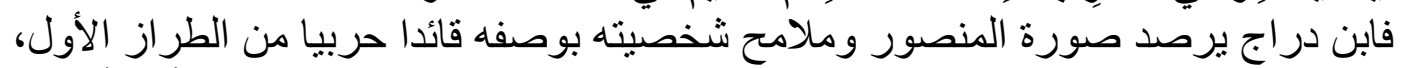

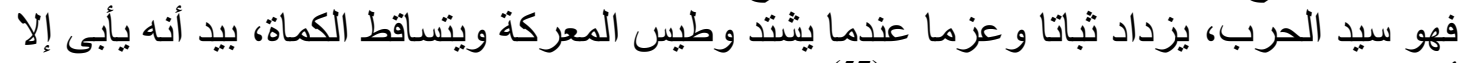

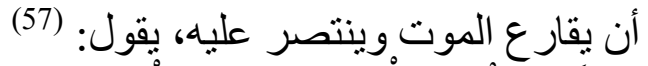
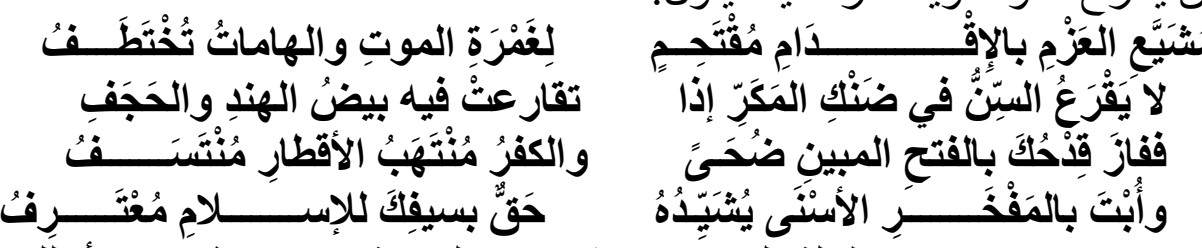

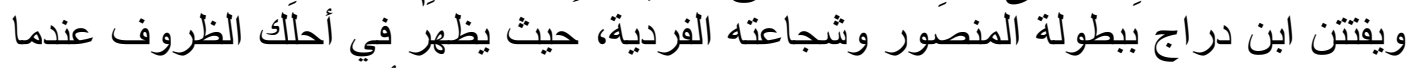

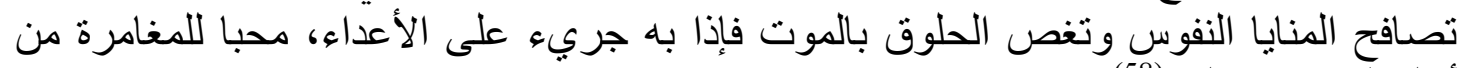

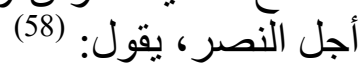
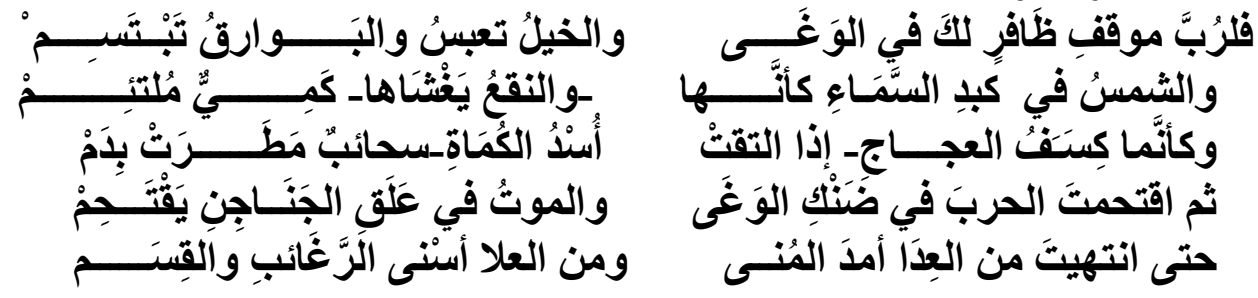


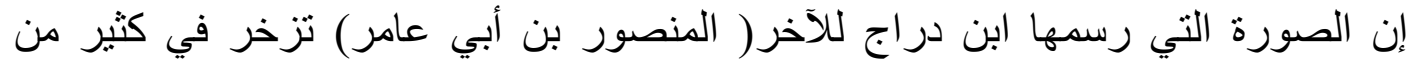

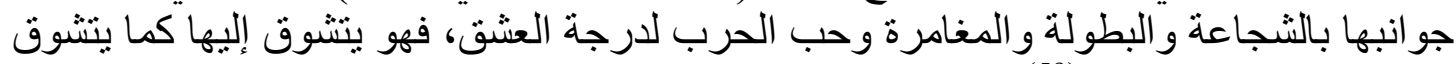

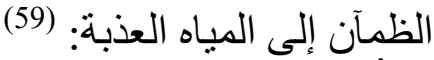

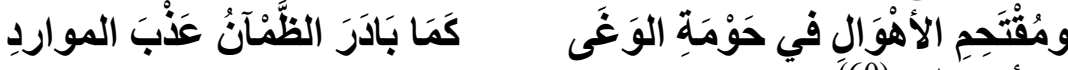
أو قوَله: (60)

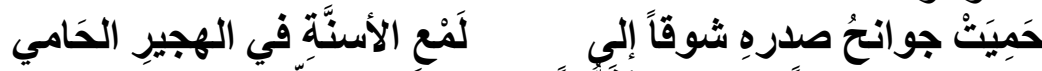

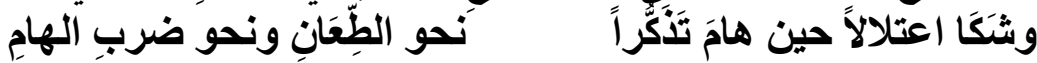

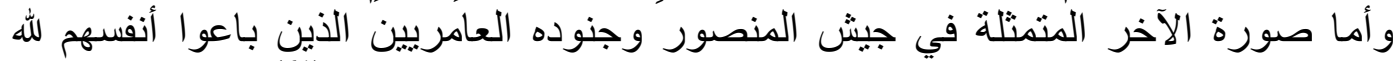

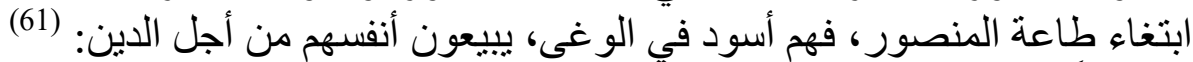

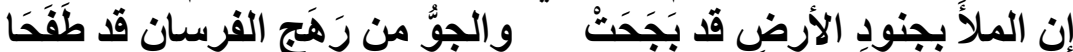

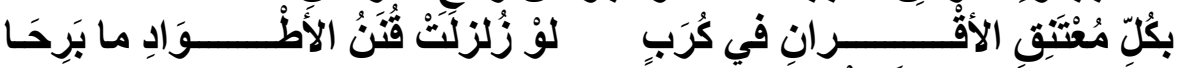

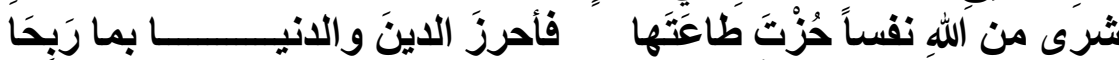

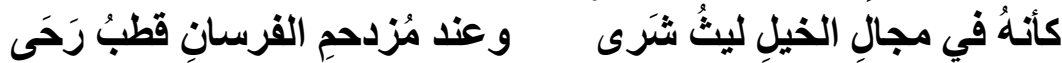

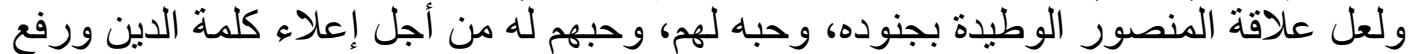

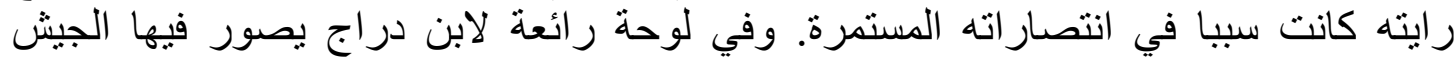

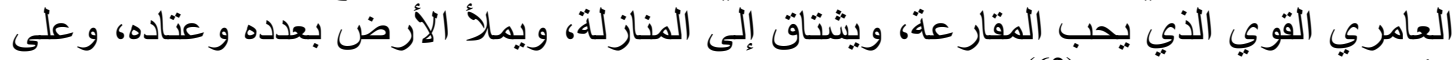
رأسه قائده الهُمام، يُقِّل: (62)
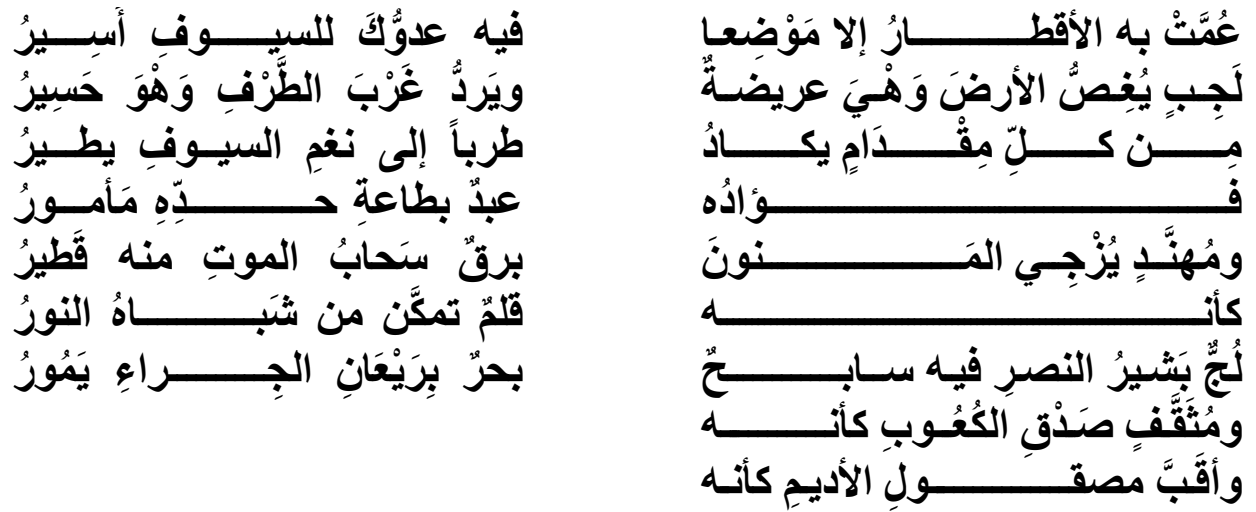

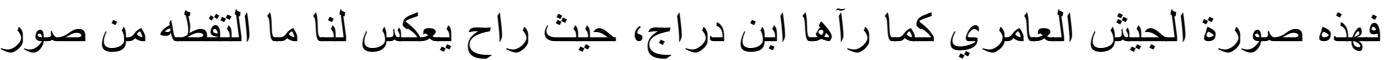

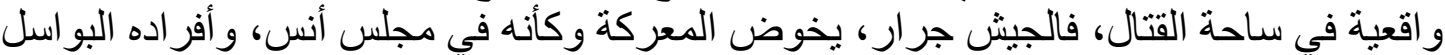

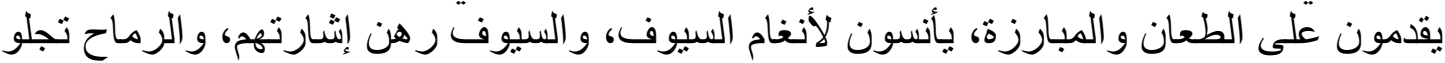

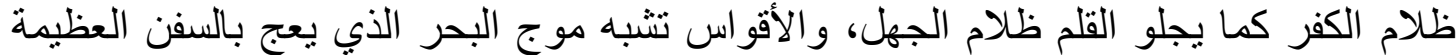
التي لا تتوقف عن الحركة.

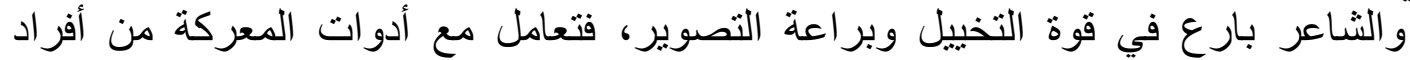

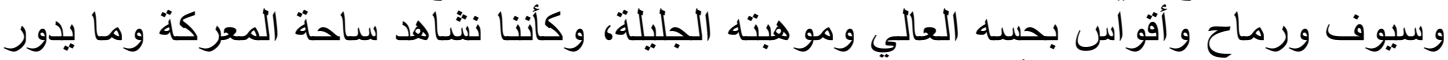

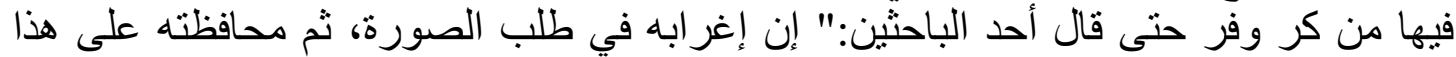

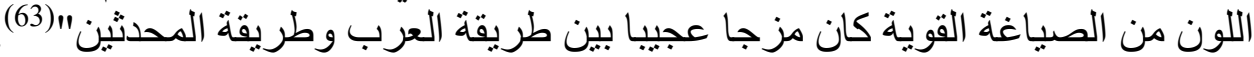

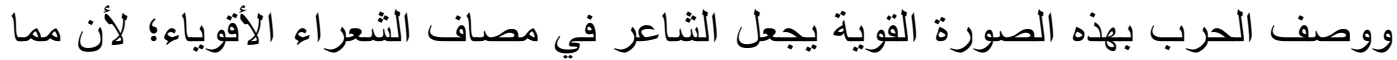

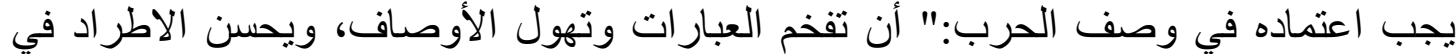

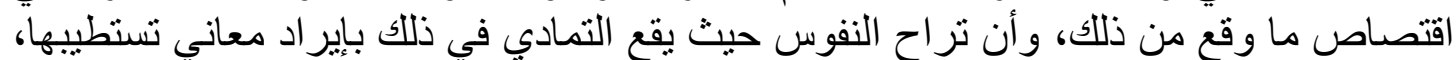

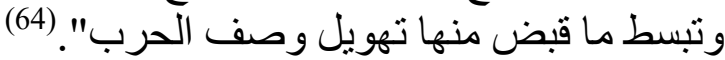


و عن أدوات الحرب المختلفة يقول ابن دراج و اصفا جياده بالظمأى التي تبحث عن الارتواء

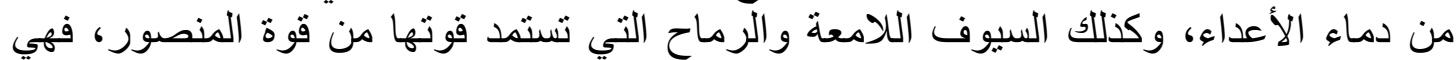

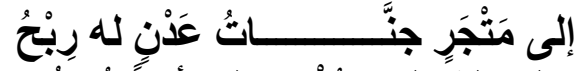

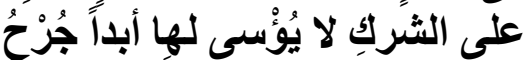

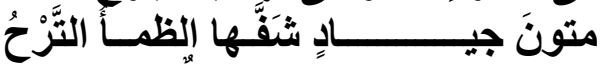

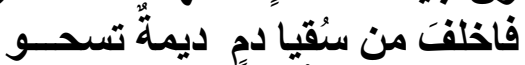

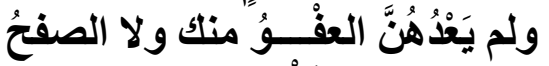

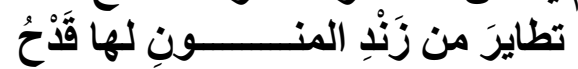

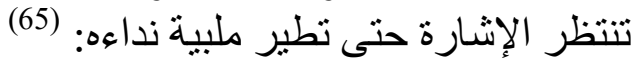

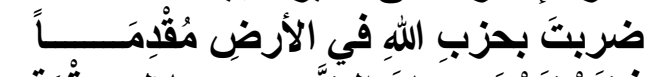

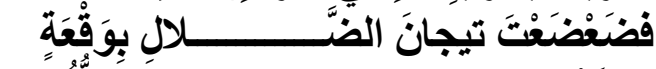

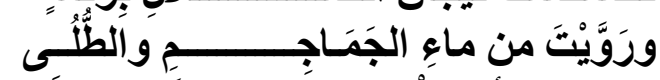

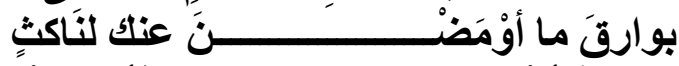

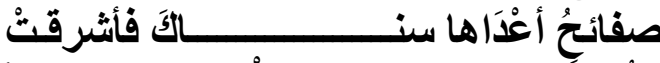
داة كأنما

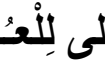
وزْزَقاً تَعَ

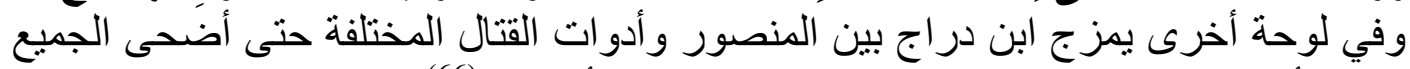

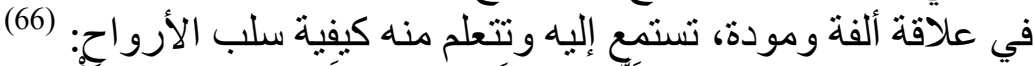

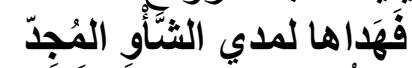

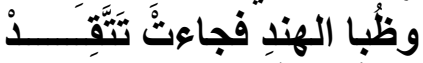

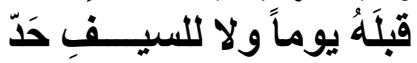
وَسَطا بساعدِ الدينِ الأشَدَّ

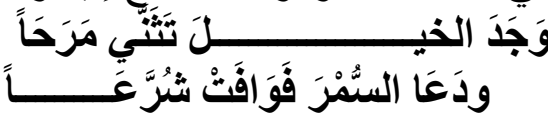

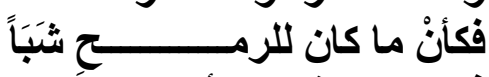

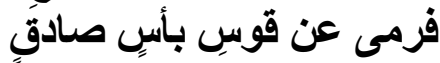

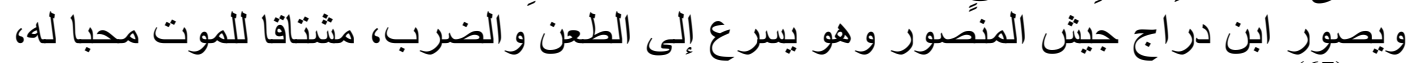
فيقول: (67)

بحرَ المهاللكِ إلا غُاضَ أو سَبَحَا

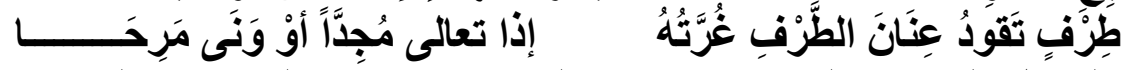

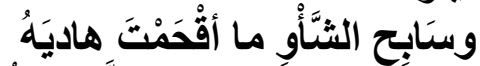

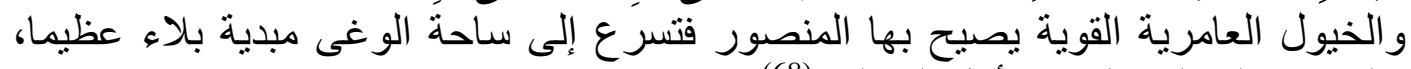

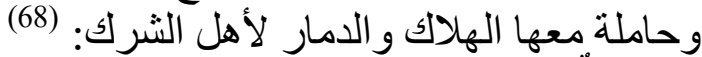

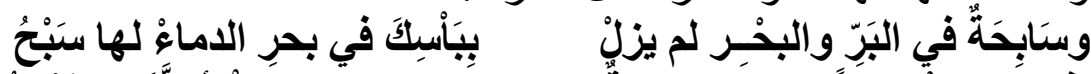

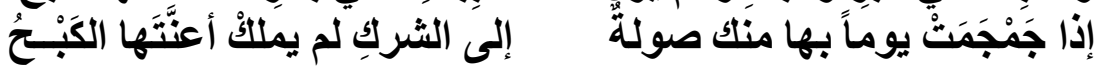

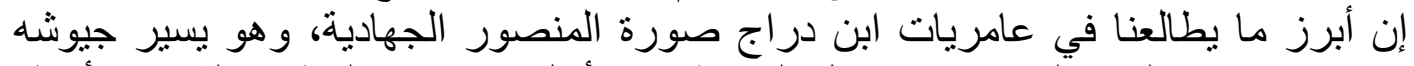

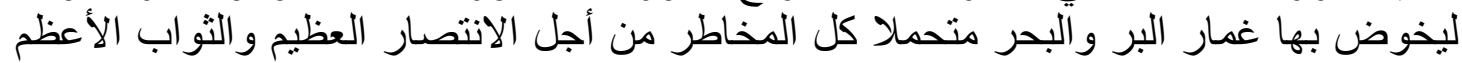

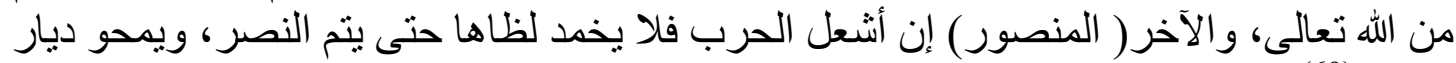
الكفر: (69)

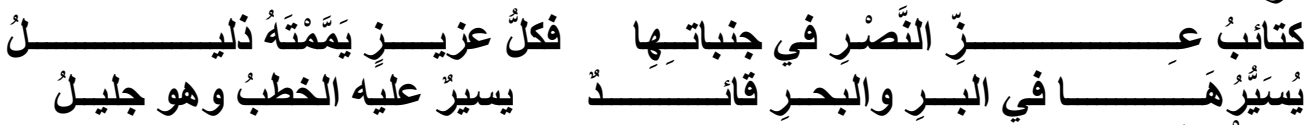

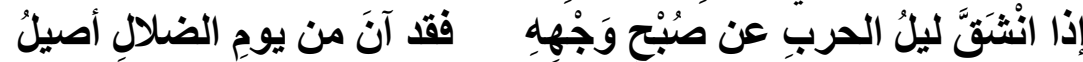

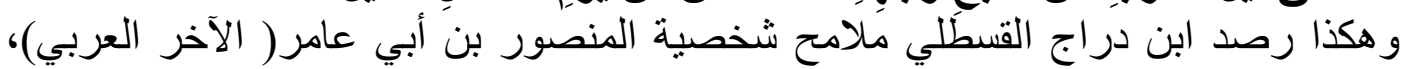

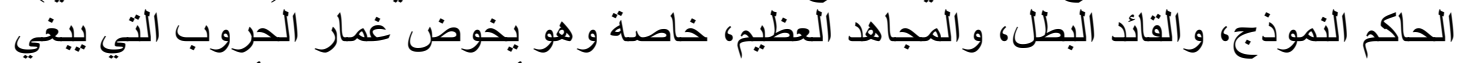
من ور اءها نصر الدين الإسلامي، وتوسيع رقعة الإسلام في الأندلس، وكان من أبرز ملامح تلكي

الشخصية القيادة الحكيمة للجيوش، والحب العميق للجنود، والسعي الدائب لنصرة الدين،

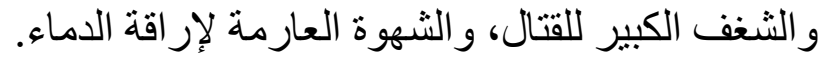

\section{المبحث الثالث صورة الآخر الأجنبي التشي}

يقصد بالآخر في هذا المبحث العدو الأجنبي النصراني الذي كان يتربص بالمسلمين، ويريد

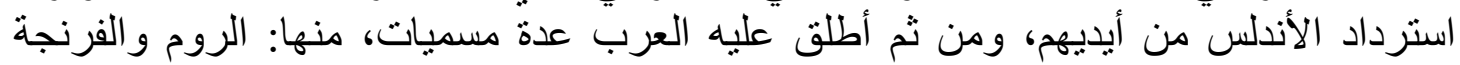


و النصارى والمجوس والنورمان، وكان هذا العدو يتمركز في شمال الأندلس - أيام الحكم

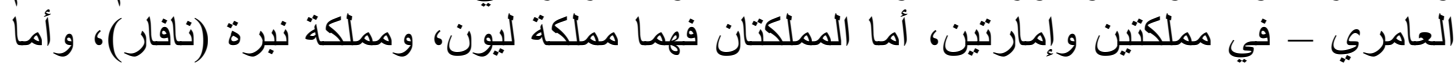

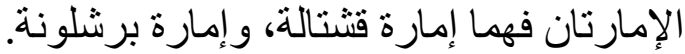

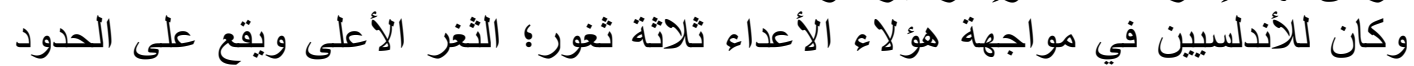

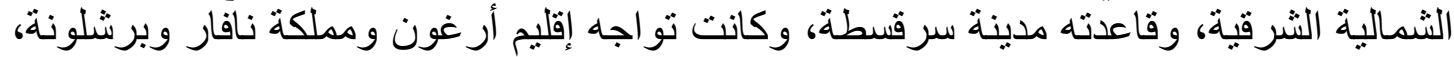

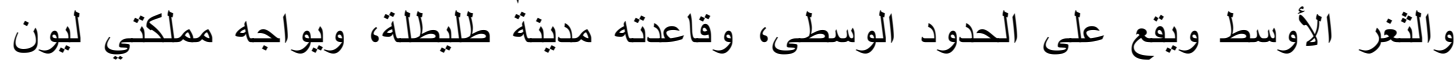

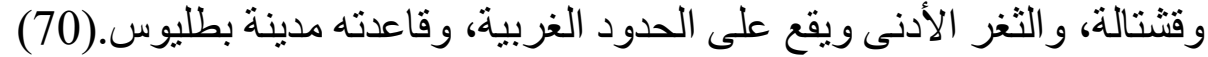

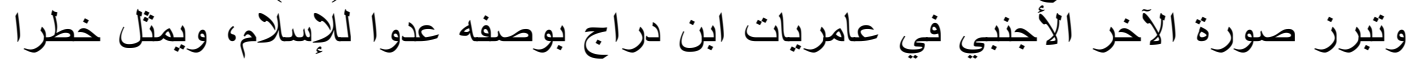

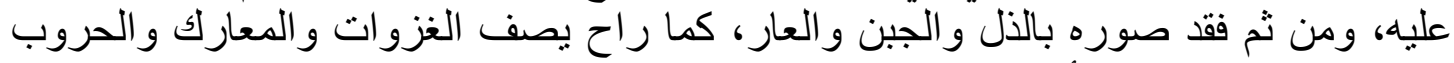

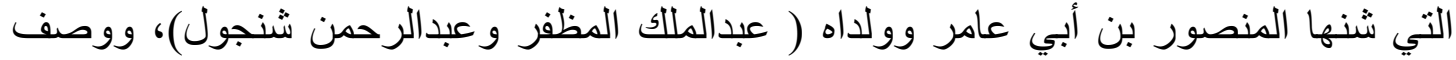

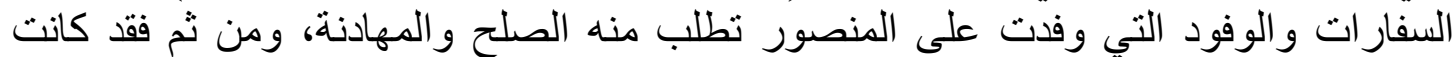

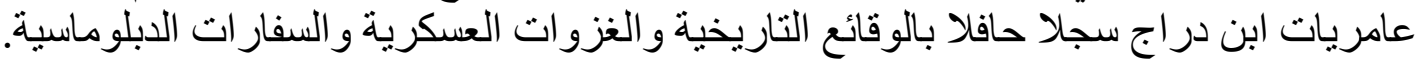

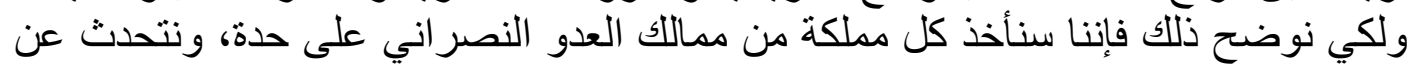

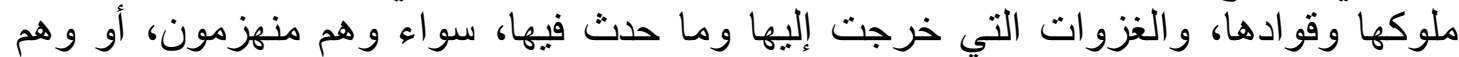

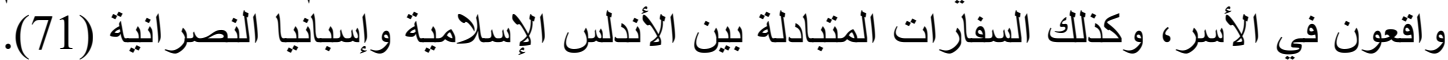

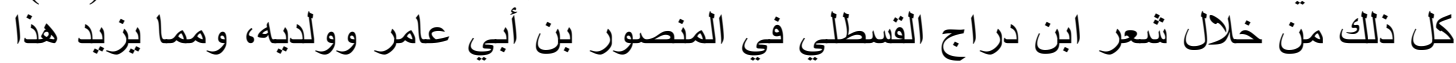

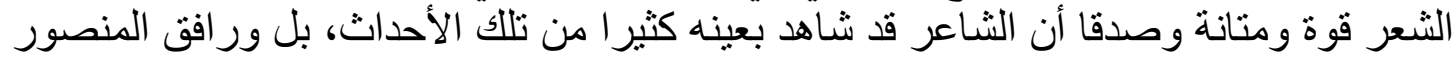
في كثير منها.

أما مملكة ليون فتعد من أقدم الممالك النصر انبة في إسبانيا ، وكانت تسمى أيام الفتح الإسلامي

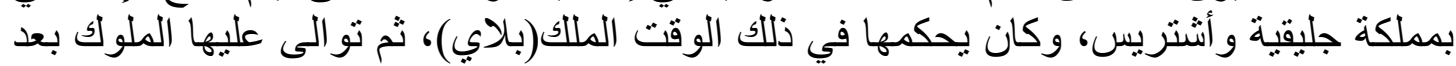
ذللك حتى جاء ألفونش الثالث(

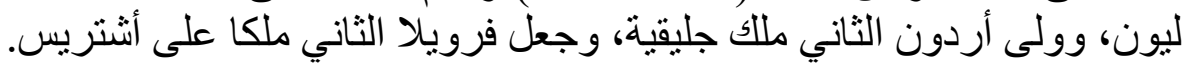

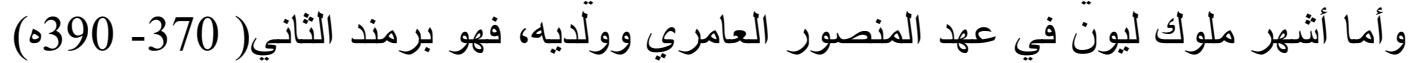

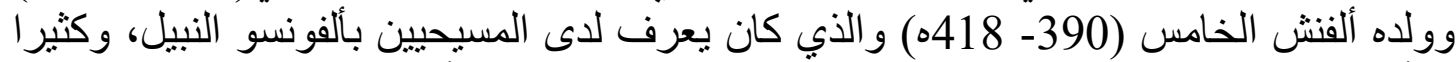

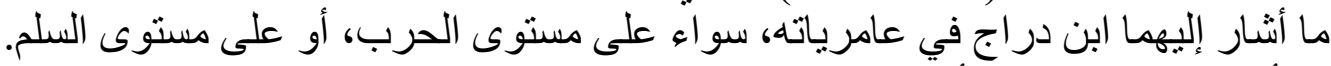

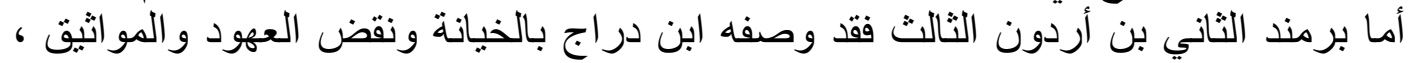

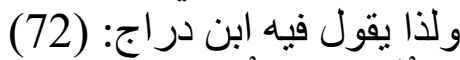

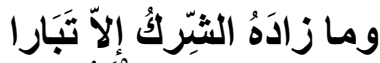

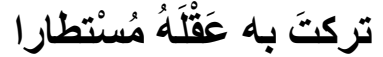

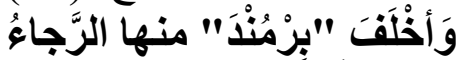

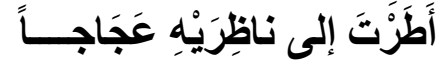

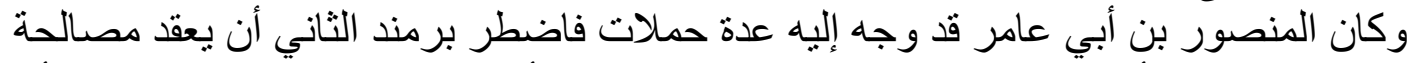

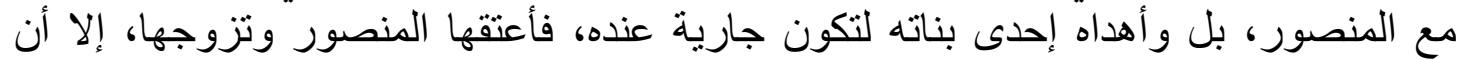

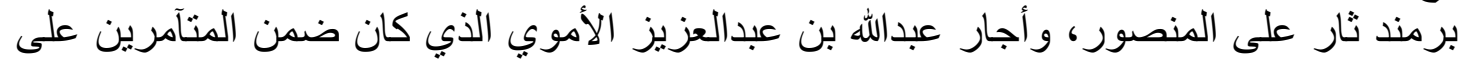

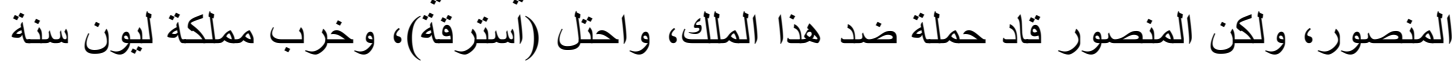

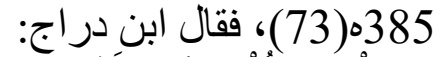

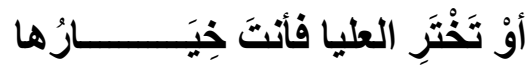

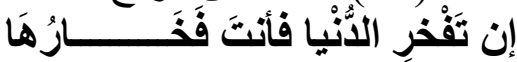

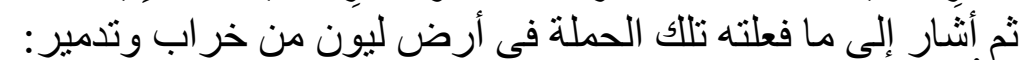

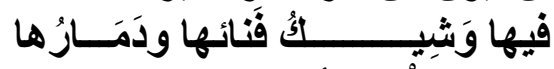

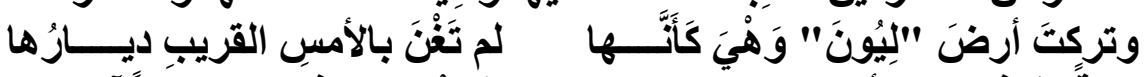

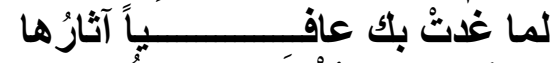

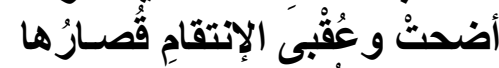

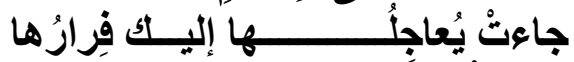

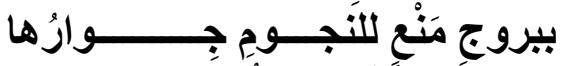

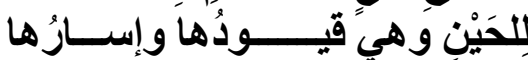

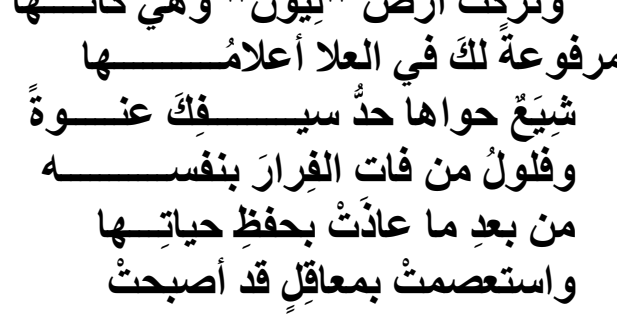




\section{ثم أثنار ابن در اج إلى خليج "دوير" الذي عبره جنود المنصور:

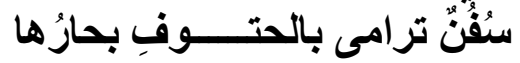

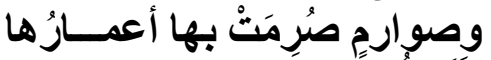

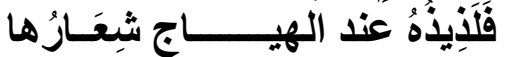

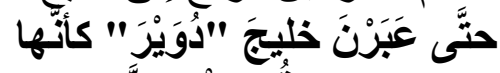

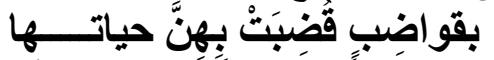

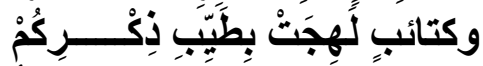

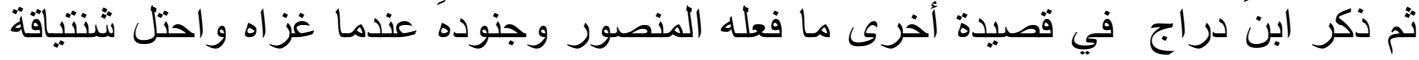

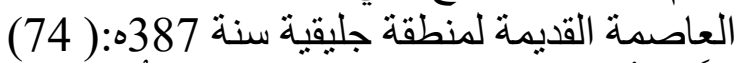

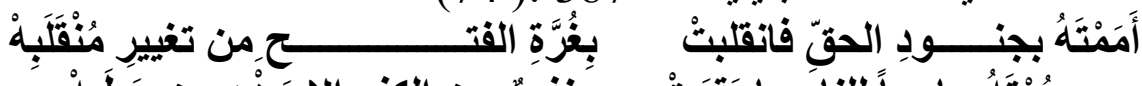

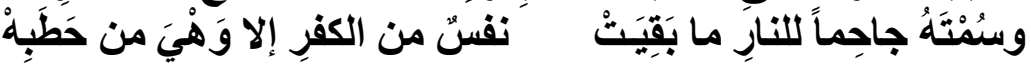

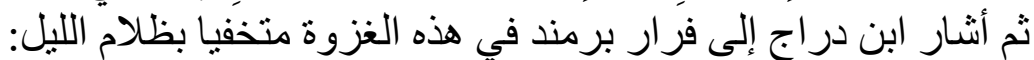

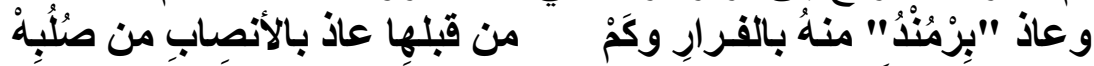

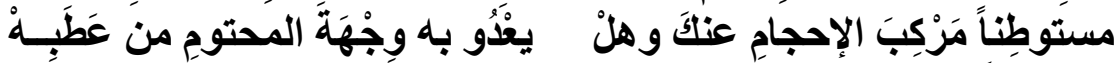

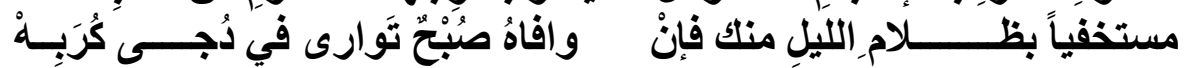

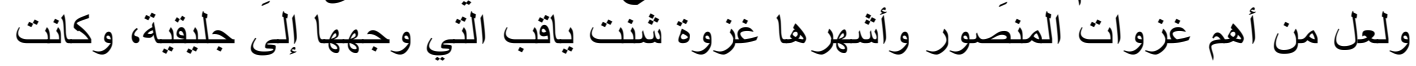

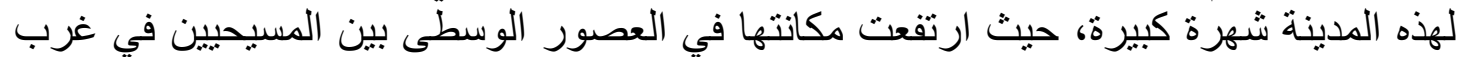

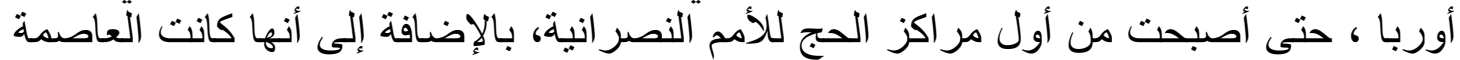

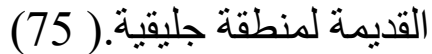

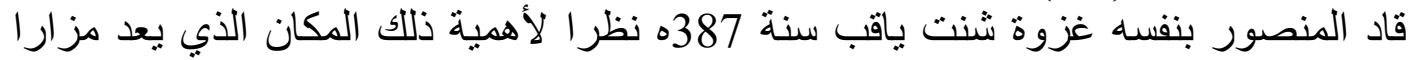

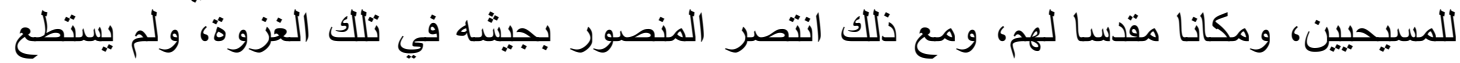

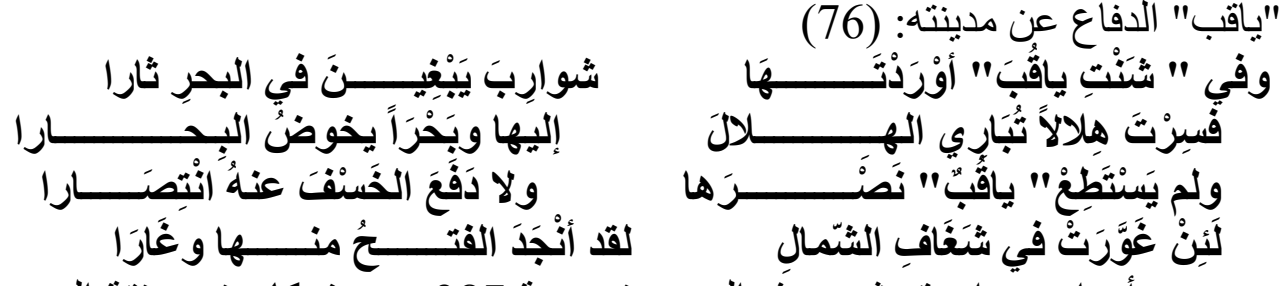

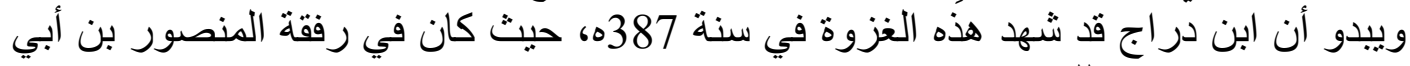

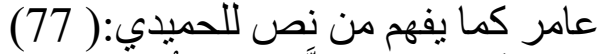

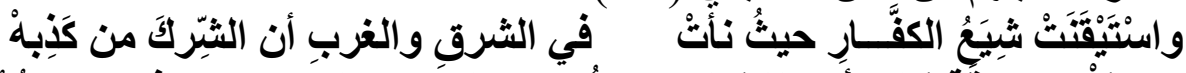

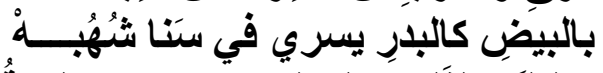

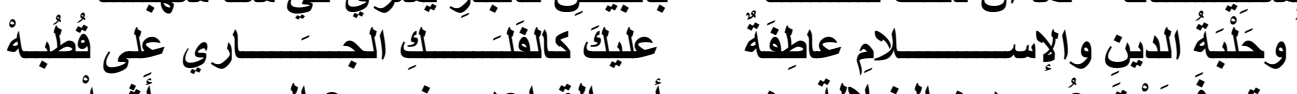

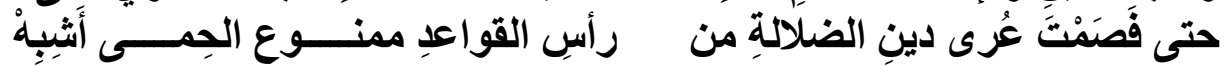

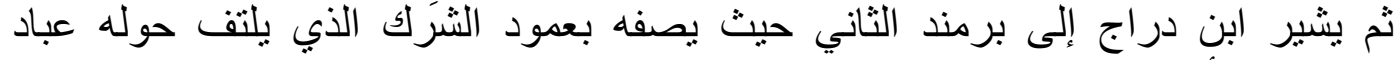

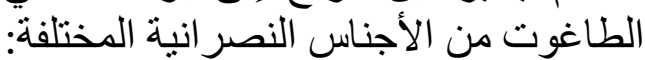

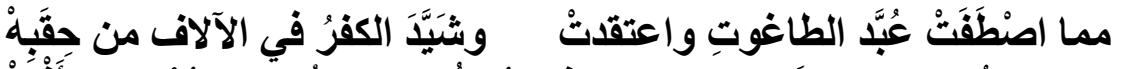

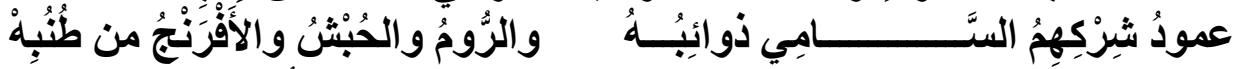

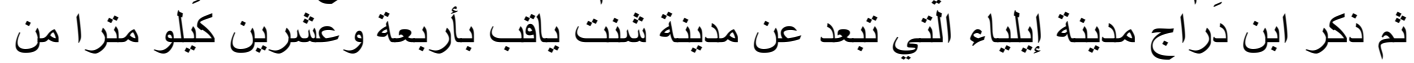

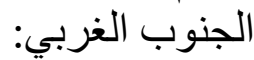

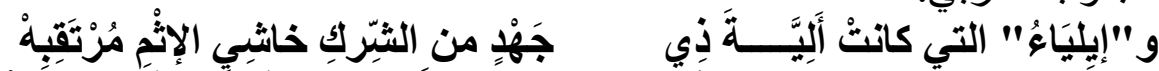

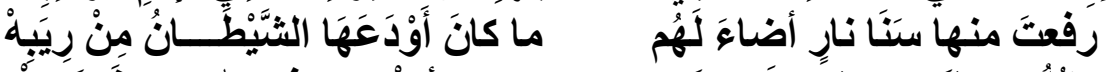

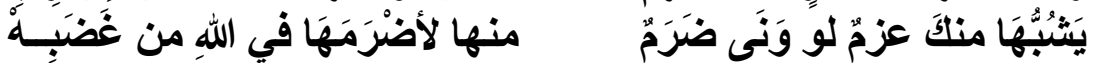

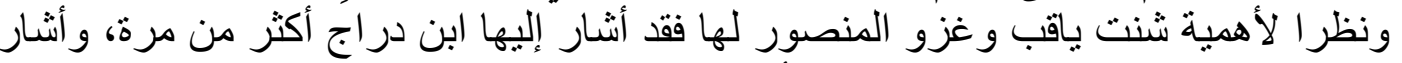

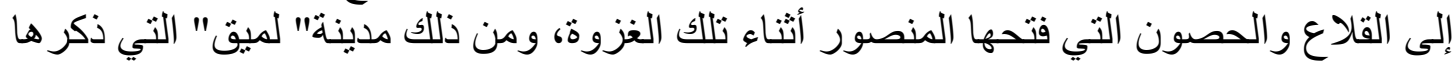

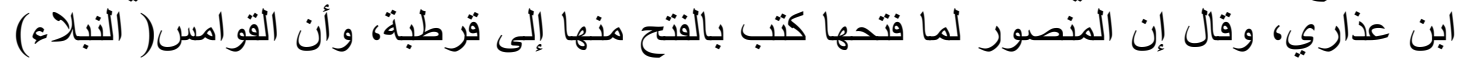

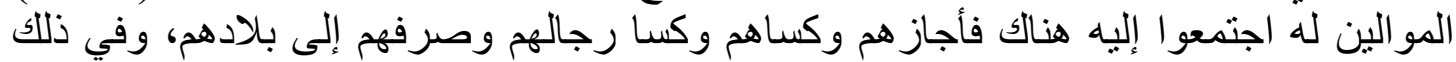

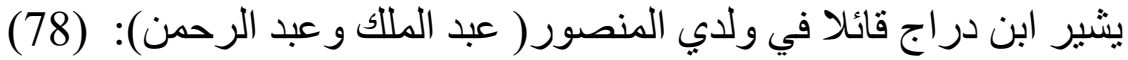




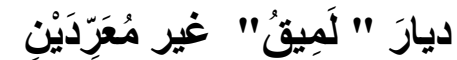

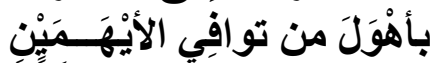

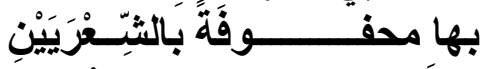

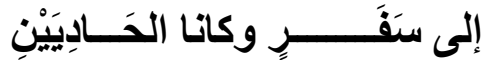

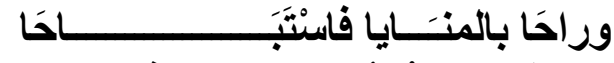

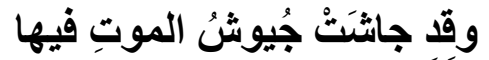

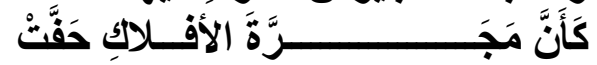

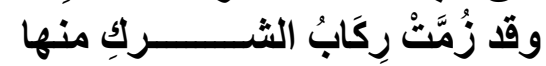

وفي هذا يشير ابن دراج أيضا إلى مدينة ( كرنة) التي تقع في مقاطعة لاكرونيا وكذلك مدينة

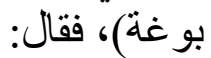

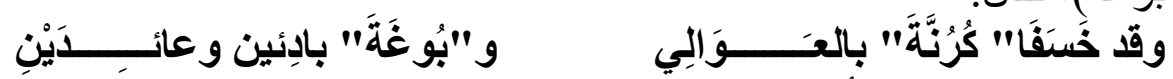

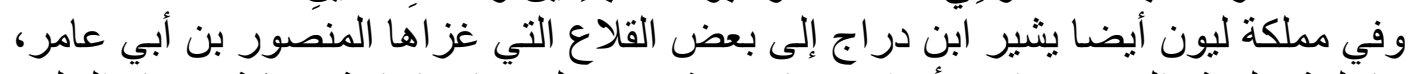

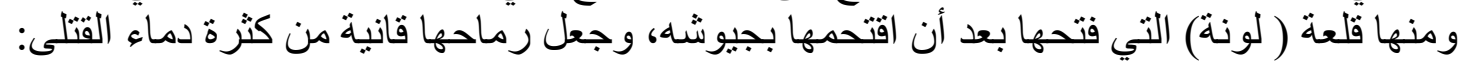

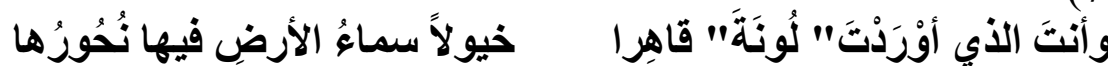

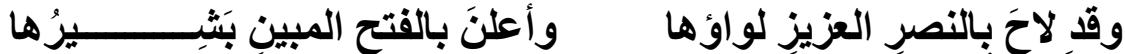

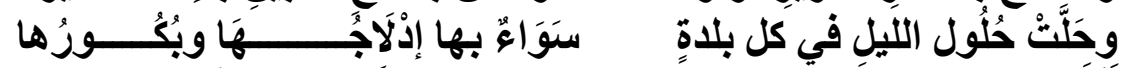

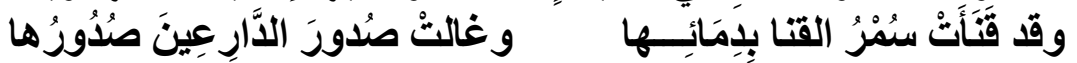

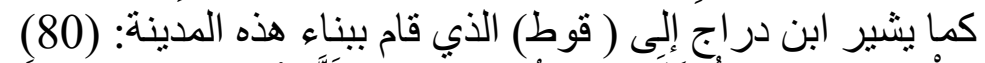

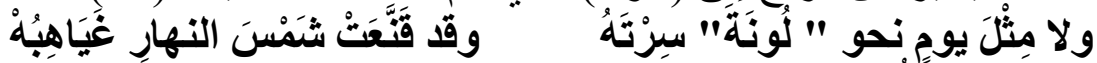

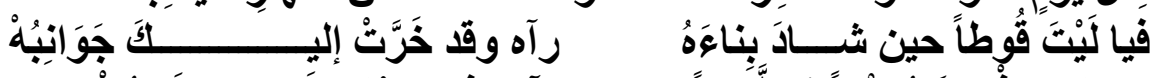

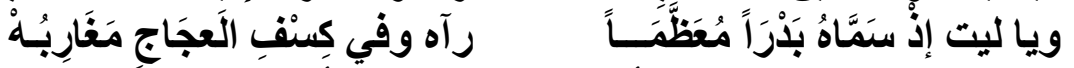

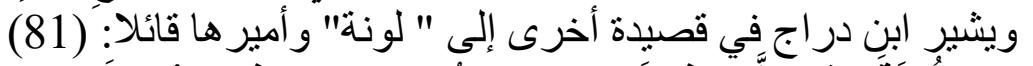

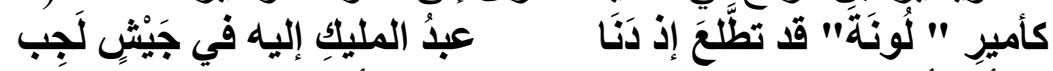

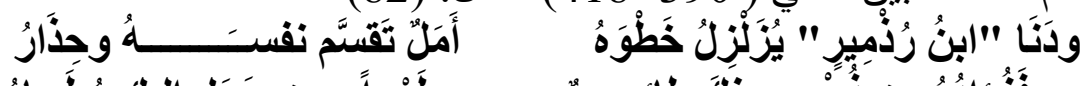

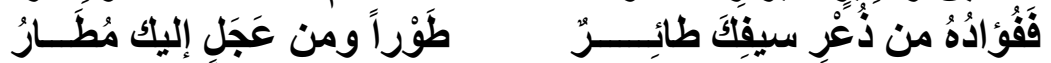

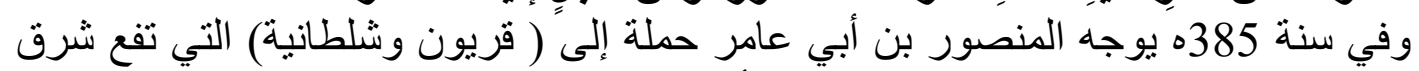

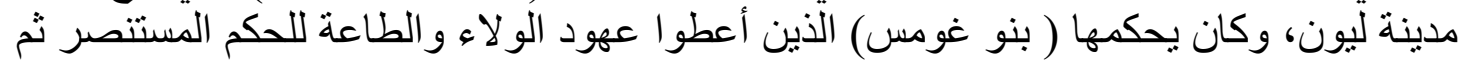

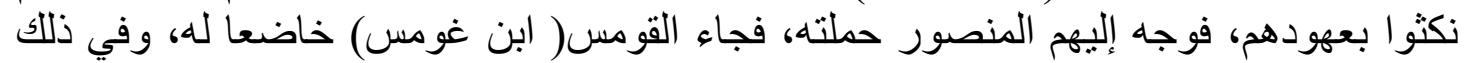

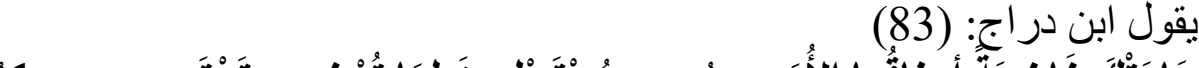

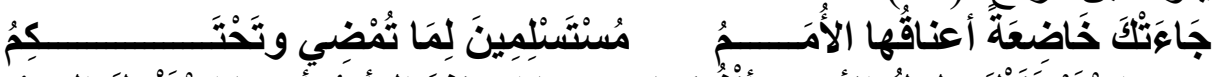

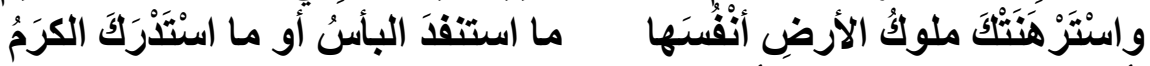

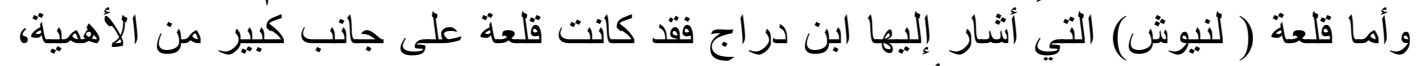

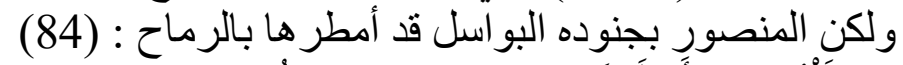

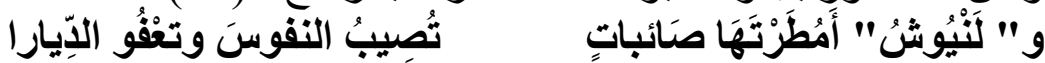

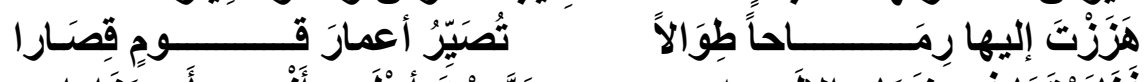

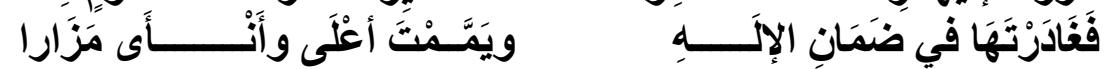

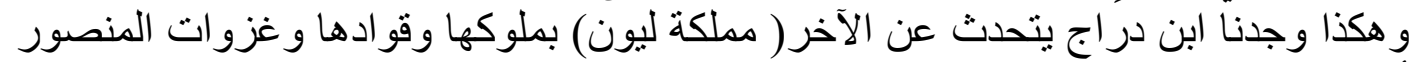

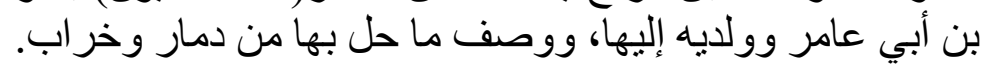

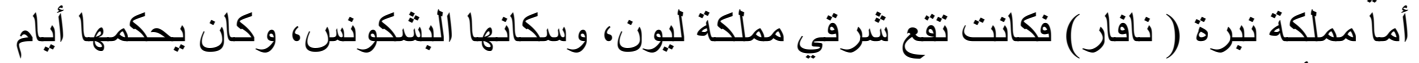

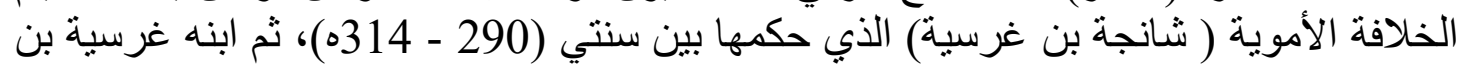

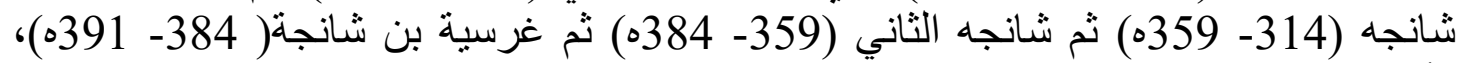
و أخير اشانجة الثالث(391- 326-326ه). 
وفي شانجة الثاني بن غرسية الأول ثالث ملوك البشكونس (359-384ه) وكان معاصرا

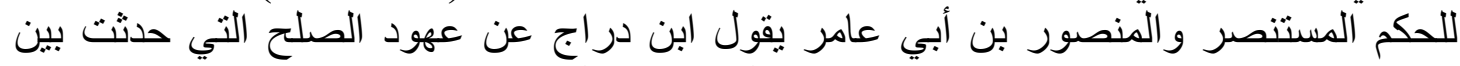

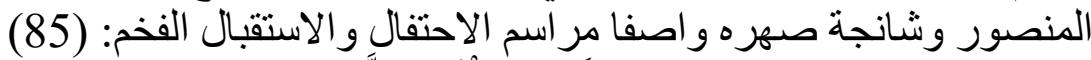

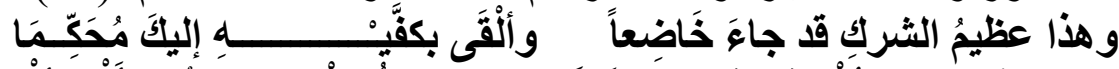

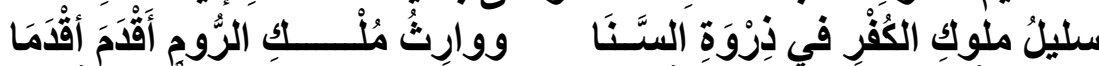

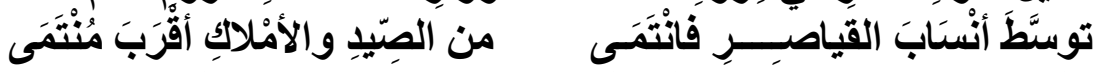

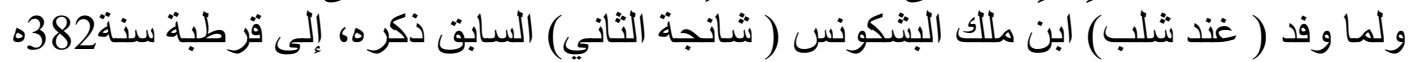

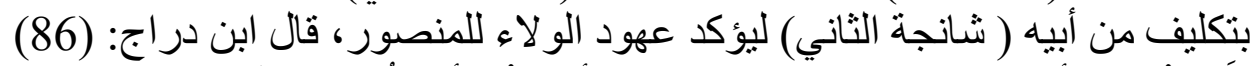

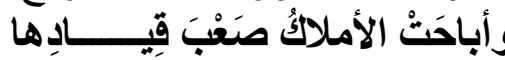

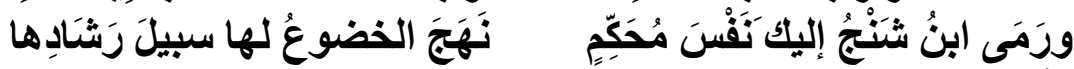

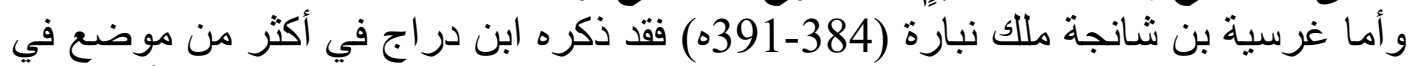

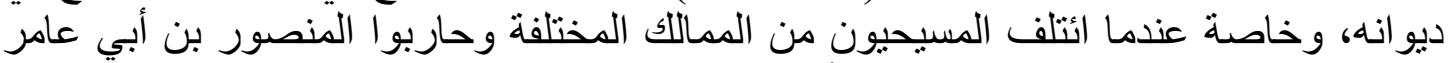

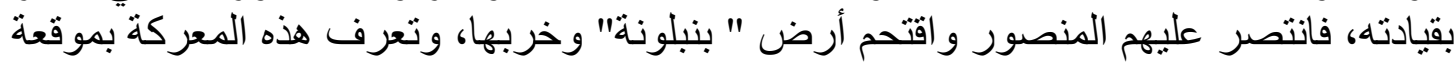

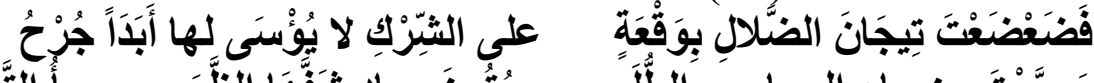

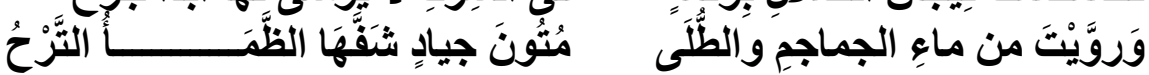

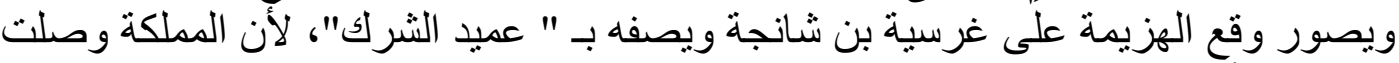

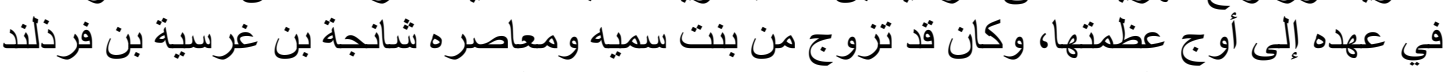

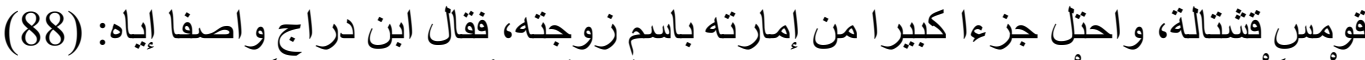

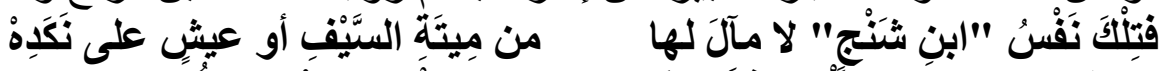

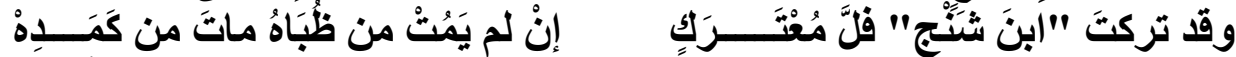

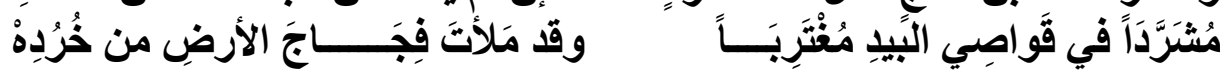

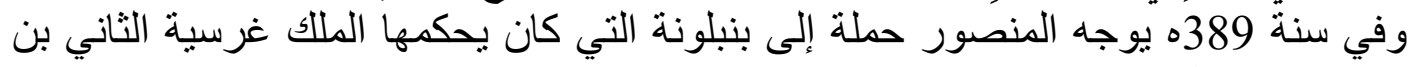

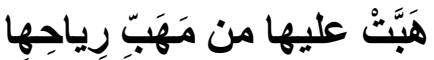

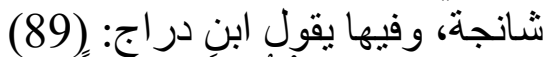

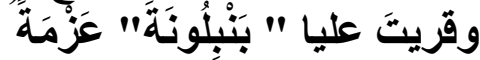

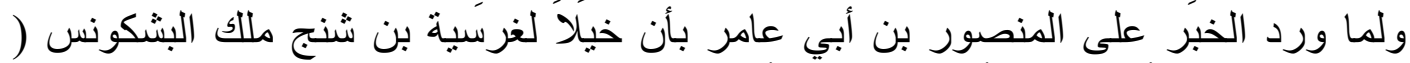

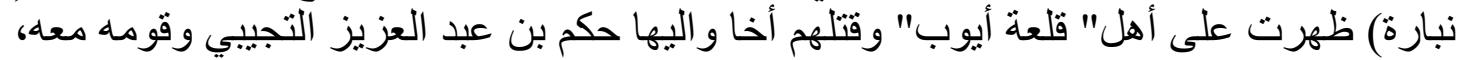

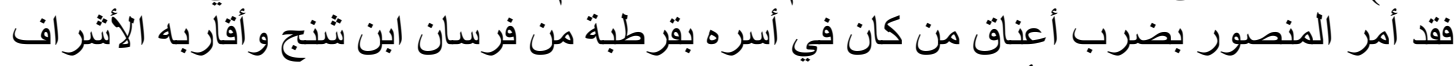

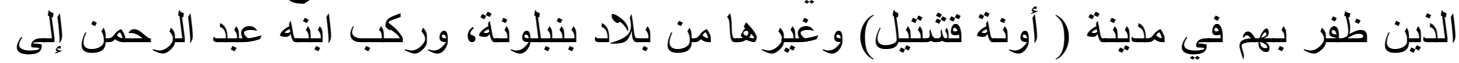

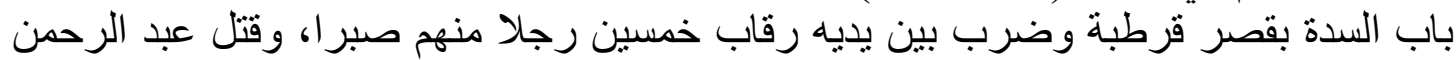

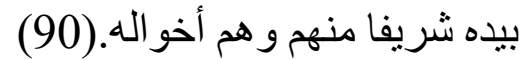

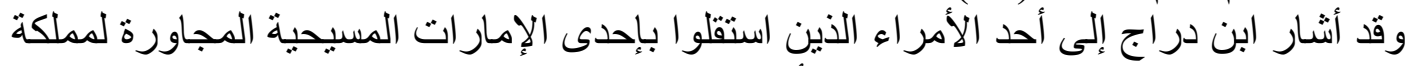

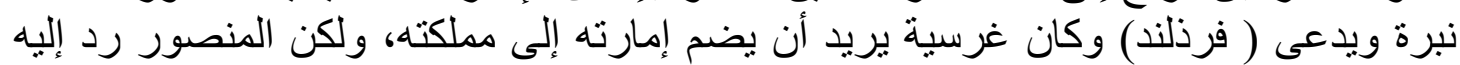

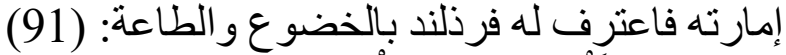

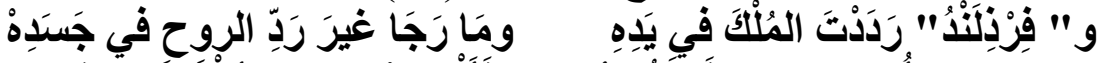

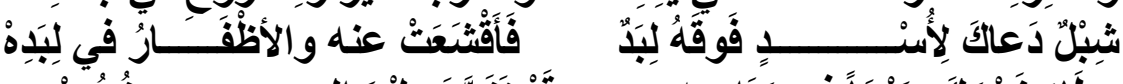

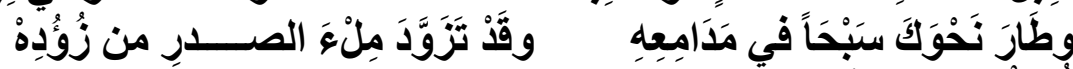

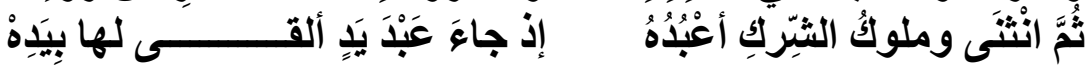

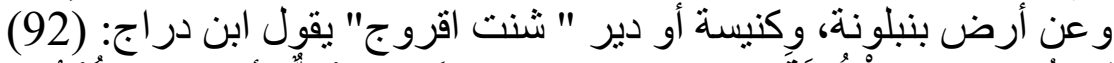

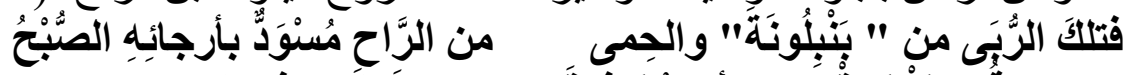

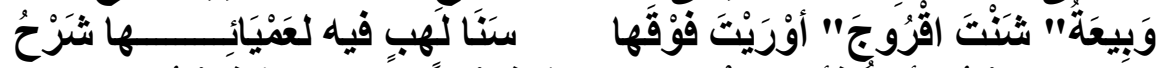

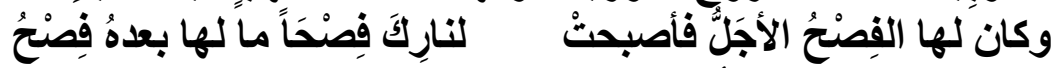
وفي غزوة جليقية أيضا يقول ابن دراجي: (93) 


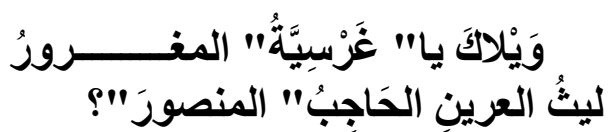

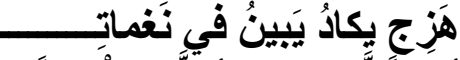

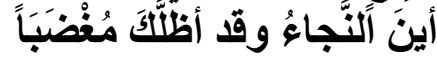

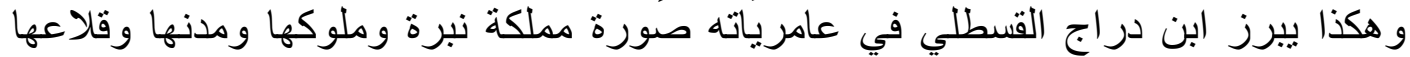

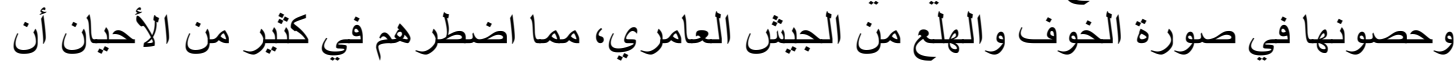

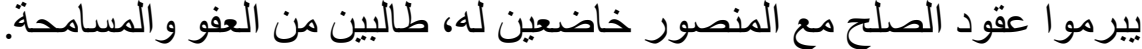

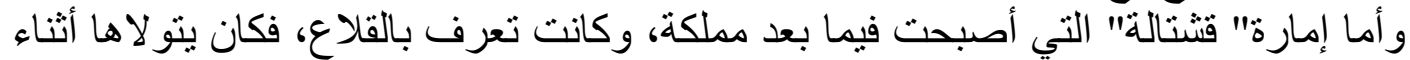

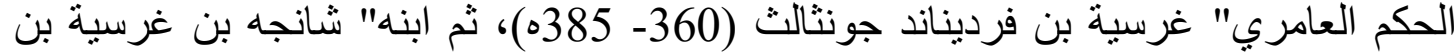

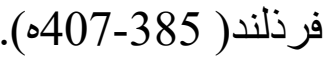

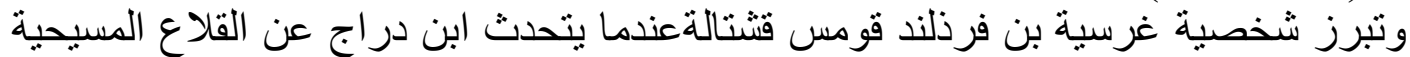

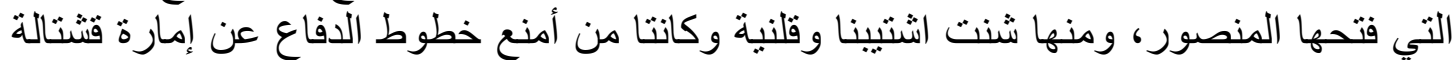

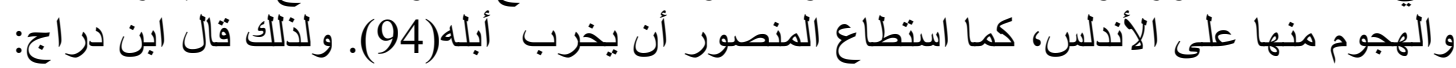

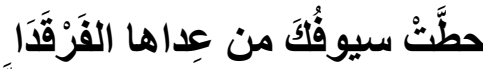

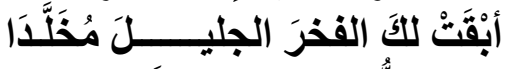

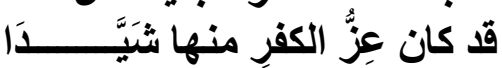

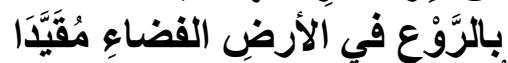

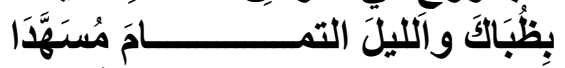

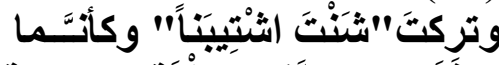

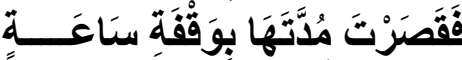

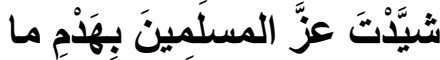

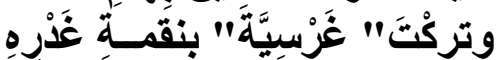

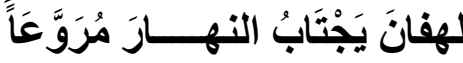

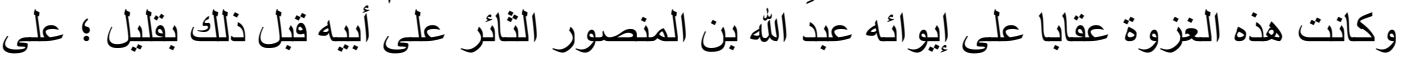

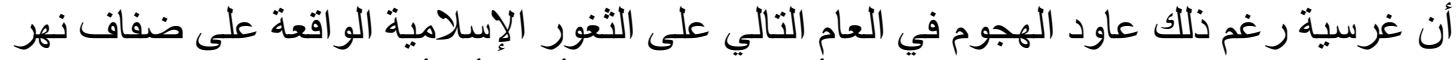

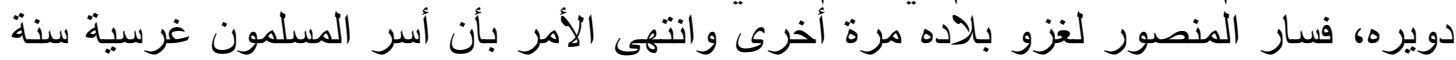

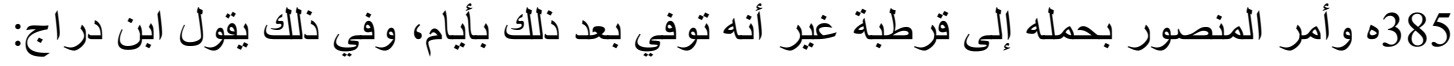

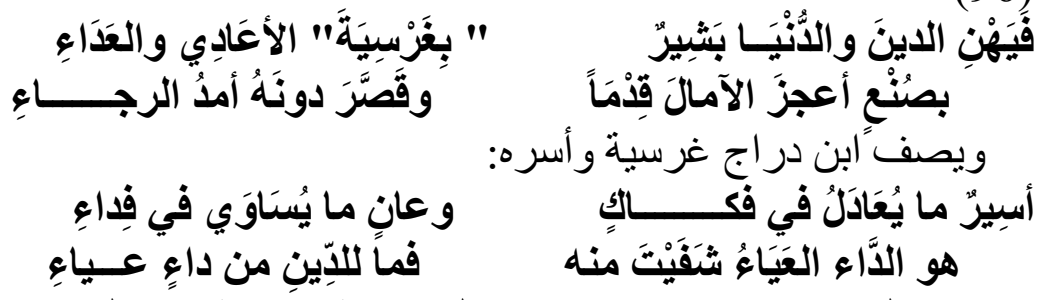

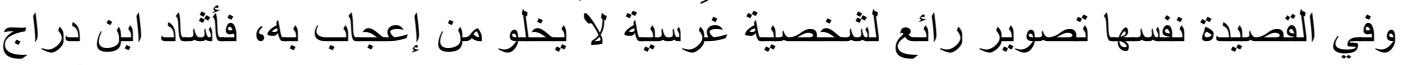

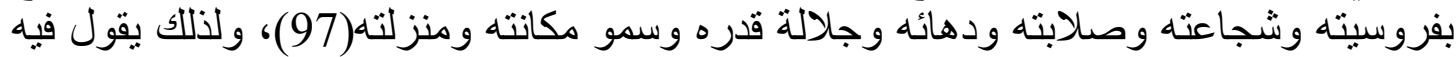

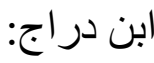

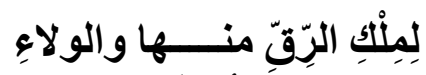

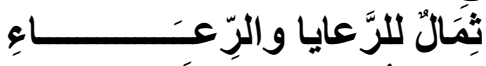
ومشفوعُ التجاربِ بالََّّهـاءِ

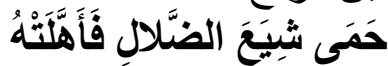

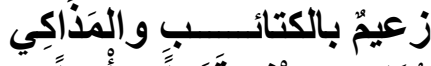

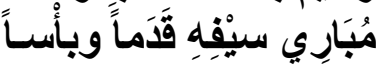

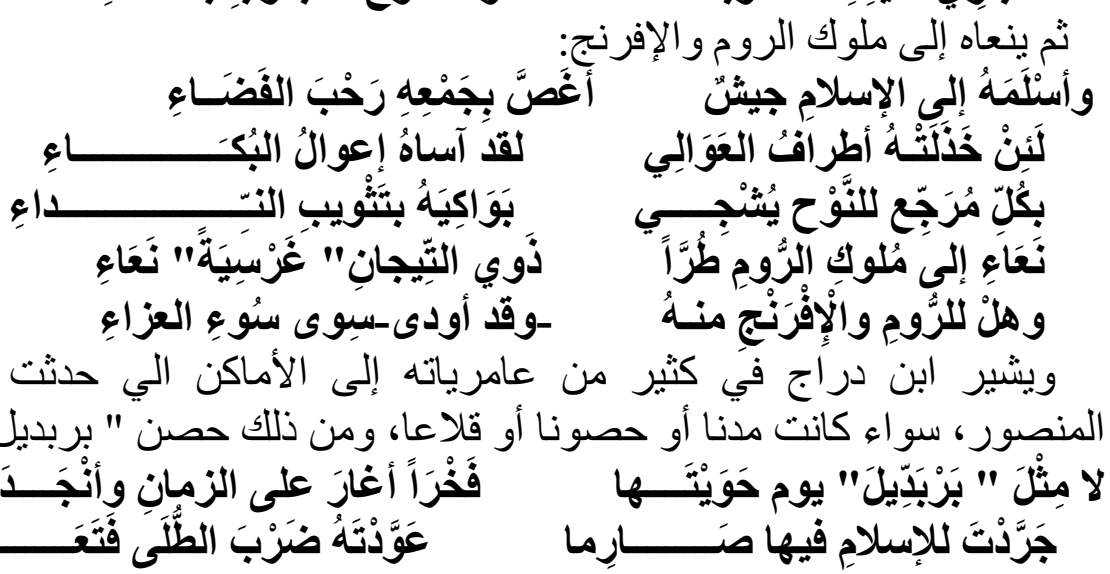




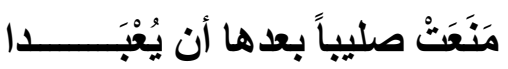

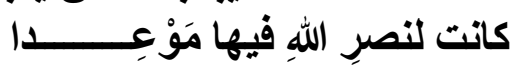

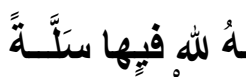
وونتَتَنَتَ

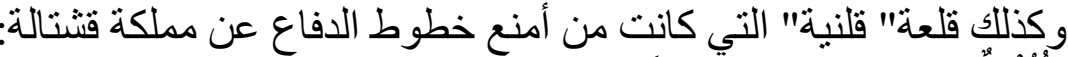

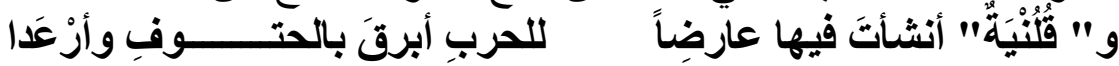

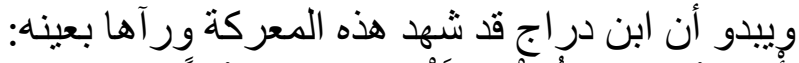

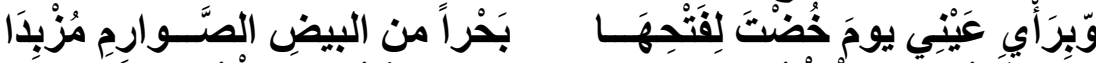

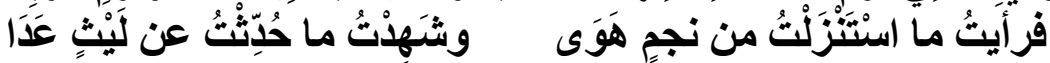

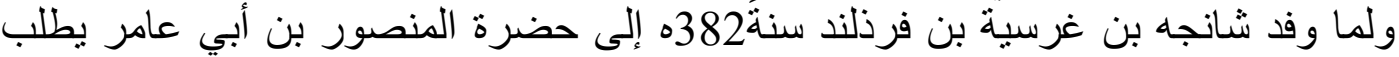

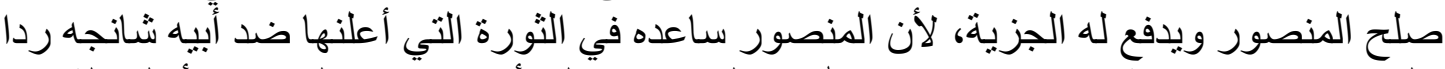

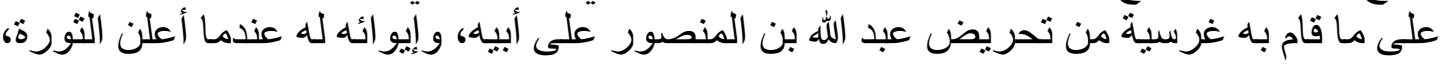

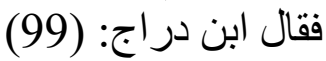

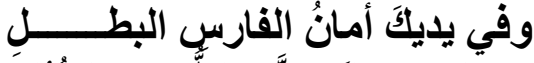

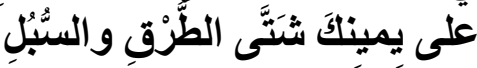

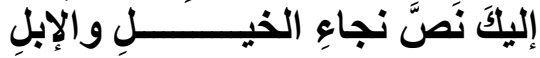

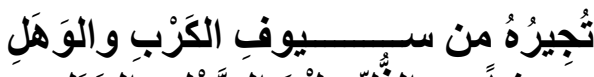

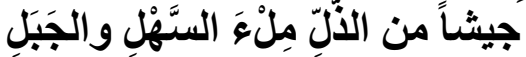

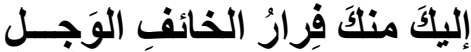

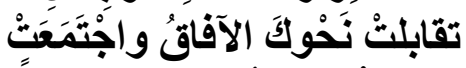

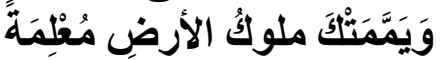

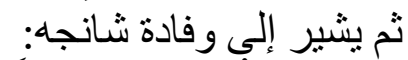

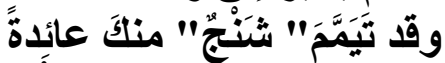

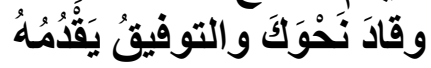

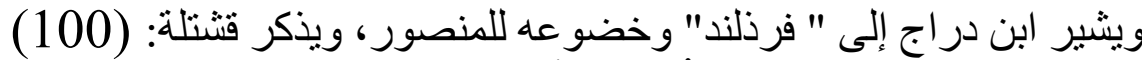

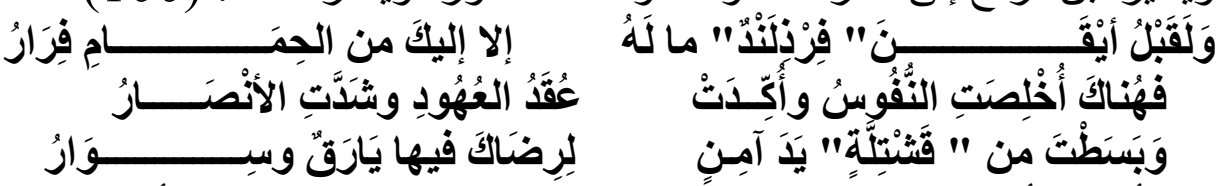

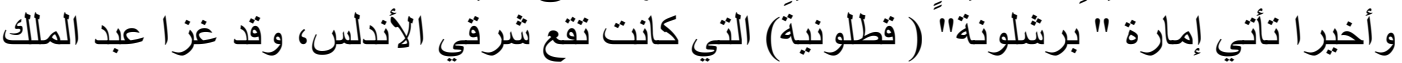

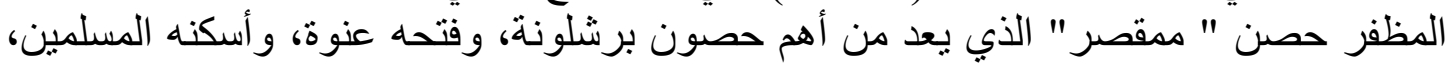

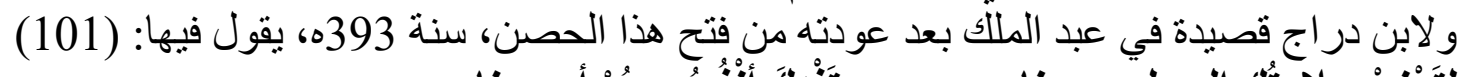

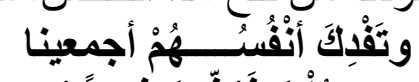

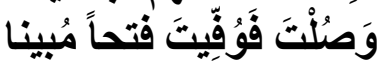

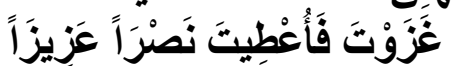

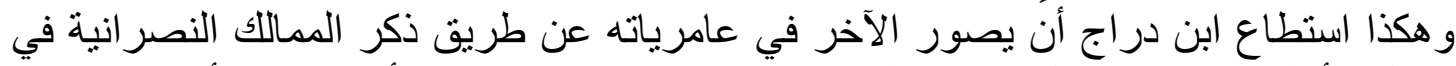

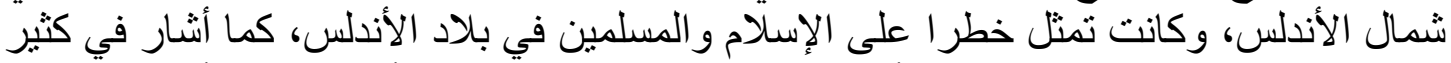

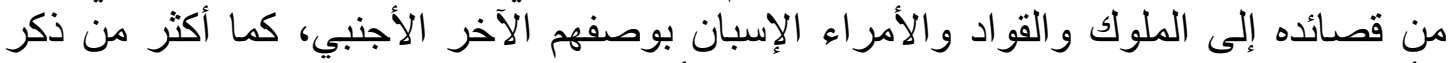

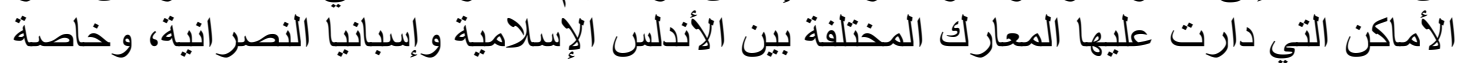

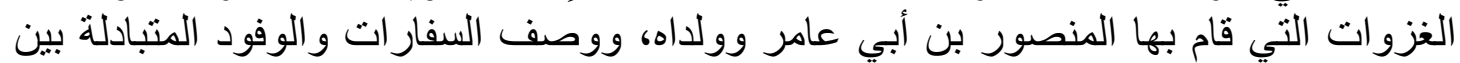

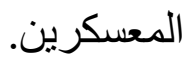




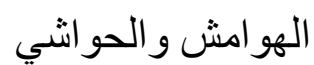

1-1ابن منظور : لسان العرب، 248/1، دار المعارف

2-جبور عبد النور : المعجم الأدبي، دار العلم للملايين، بيروت، لبنان، ط 1984/2، ص 136

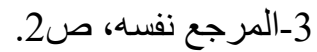

4-د.أحمد ياسين السليماني: التجليات الفنية لعلاقة الأنا بالآخر في الثعر العربي المعاصر ، دار الزمان،

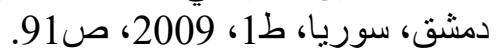

5-د.دعبد الرحمن ححمح عيسوي: اتجاهات جديدة في علم النفس الحديث، دار النهضة العربية بيروت، لبنان،

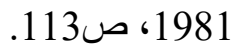

6_أنس شكثاك: أسرار الشخصية وبناء الذات، دار الكتاب العربي، بيروت، لبنان، 2009، صـ 3

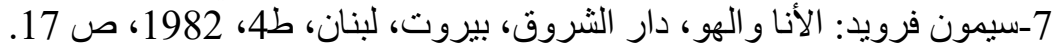

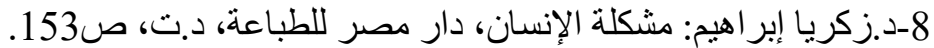

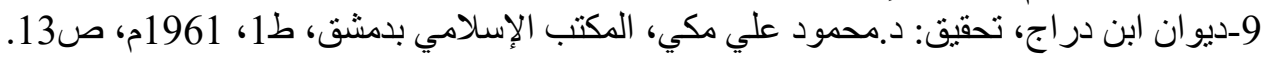

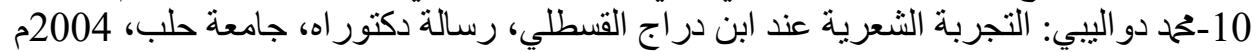

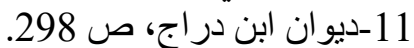

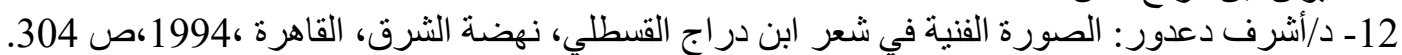

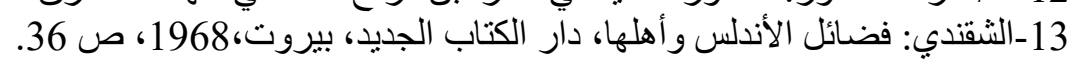

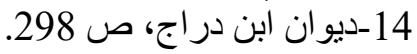

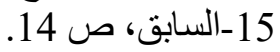

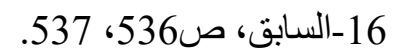

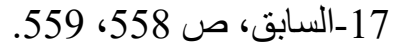

18-18/أحمد هيكل: الأدب الأندلسي من الفتح إلى سقوط الخلافة، دار الدعارف، القاهرة، ص 326.

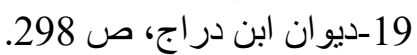

20- د/أنشرف دعدور : الصورة الفنية في شعر ابن دراج القسطلي، صالقد 302. 21-سراج الدين مححم: الفخر في الثعر العربي، سلسلة المبدعون، دار الر اتب الجامعية، بيروت، لبنان، د. ت.

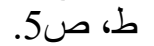

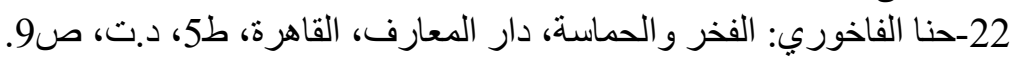

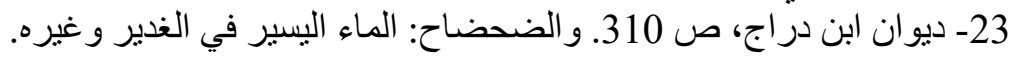

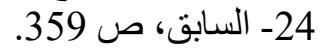
25-السابق، ص 25 366. 26-السابق، ص 25 365.

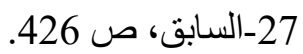

28_السابق، ص 2700، 201، 301.

29-السابق، ص434. 30-السابق، ص 29 صـ40.

31-السابق، ص460 ص45

32-السابق، ص ص235 355

33-السابق، ص422.

34-السابق، ص 366 ـ365.

35-السابق، ص365. صن صن

36-السابق، ص 36 الساب، صن 37-السابق، ص 423. 


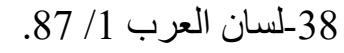

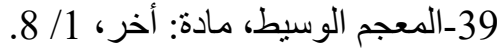

40-مي عودة أحمد ياسين: الآخر في الثعر الجاهلي، رسالة ماجستير، جامعة النجاح، كلية الدراسات العليا،

$$
\text { ص6. }
$$

41-ديو ان ابن در اج، المقدمة، ص 48.

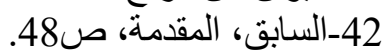

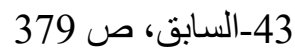

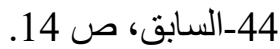

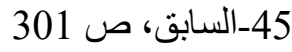

46-المر اكثي: المعجب في في تلخيص أخبار المغرب، شرح: صلاح الدين الهواري، المكتبة العصرية، ص 38

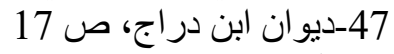

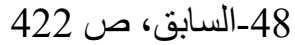

49-السابق، ص 48 408، 409 409 40

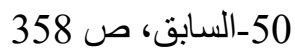

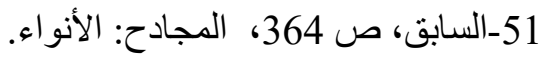

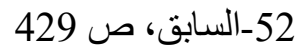

53_السابق، ص 52 371، الزيان، ص29 الزود: الرهبة والخوف.

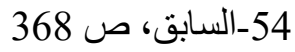

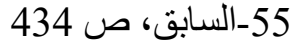

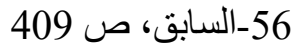

57-السابق، ص صابق، 361، 362، 362، الجحف: التروس المصنو عة من الحبال.

58_السابق، ص 521 421، 422، 367، الجناجن: عظام الصدر.

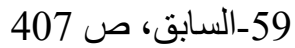

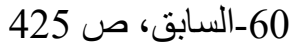

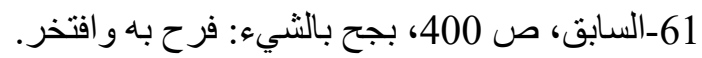

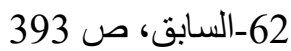

63-إحسان عباس: 6اريخ صاريخ الأدب الأندلسي، عصر سيادة قرطبة، ص 241.

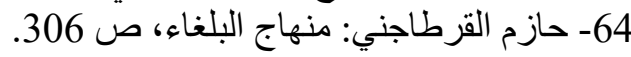

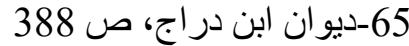

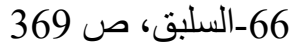

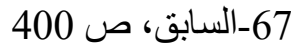

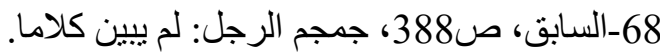

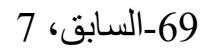

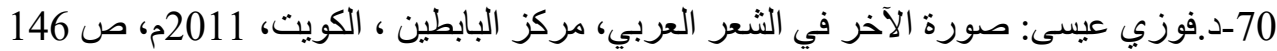

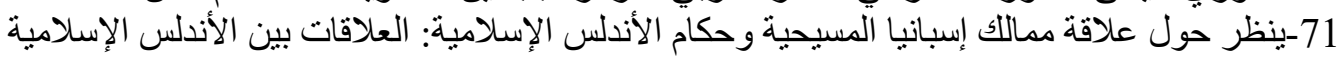

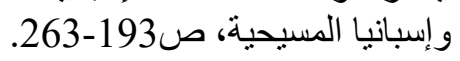

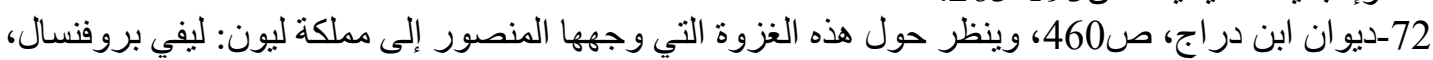

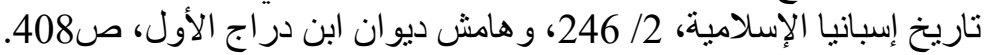

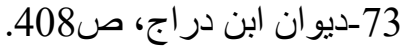

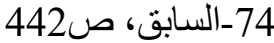

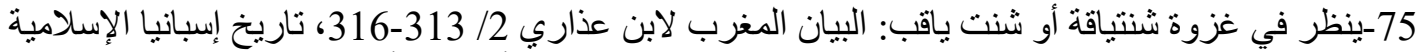

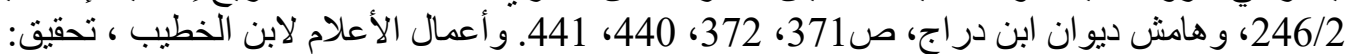

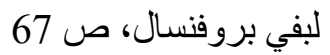

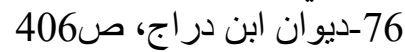

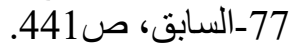

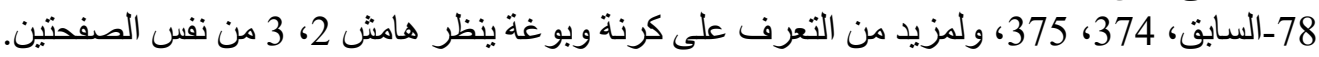

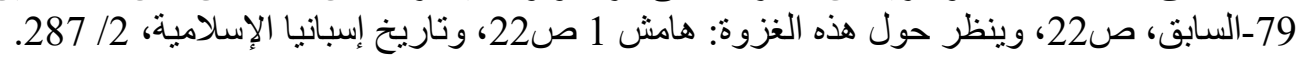

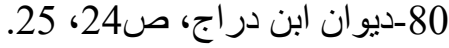

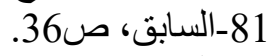

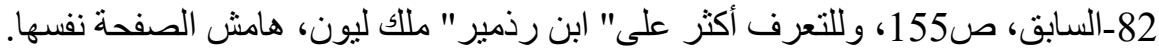




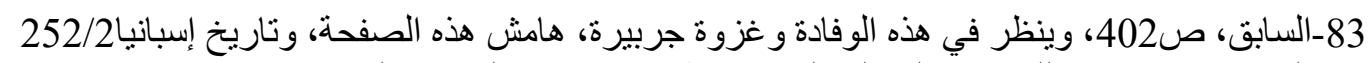

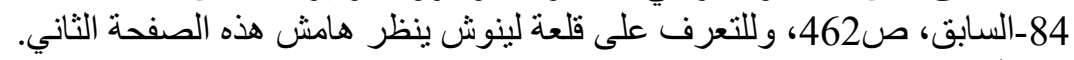

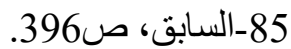

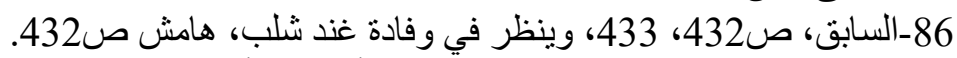

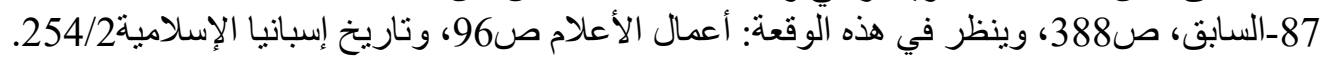

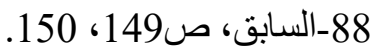

89_السابق، ص384، 149، وينظر في غزوة بنبلونة سنة3299، هامش ص3813، 382 من الديوان.

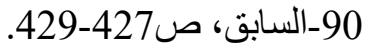

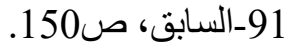

92-السابق، ص39139، وينظر هامش الصفحة للتعرف على دير" شنت افروج".

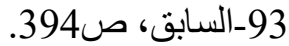

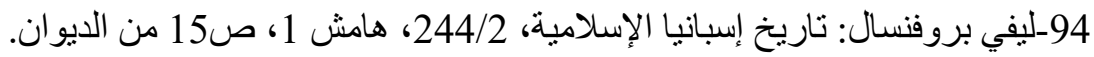

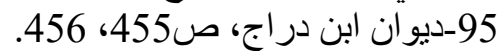

96-بنظر هامش صدان ابن دراج، ص35، 436 من الديوان.

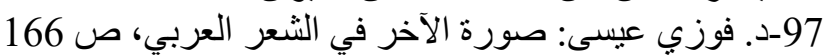

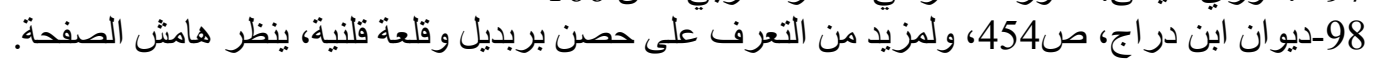

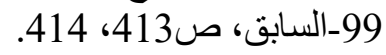

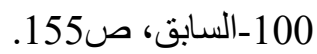

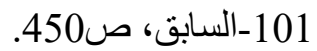

\section{الخاتمة}

تمخض هذا البحث عن عدة نتائج؛ منها:

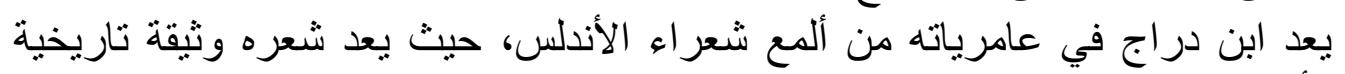

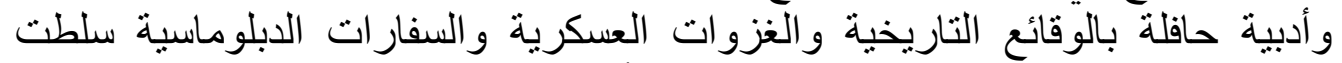
الضوء على فترة مهمة من فتر ات المسلة المسلمين بالأندلس.

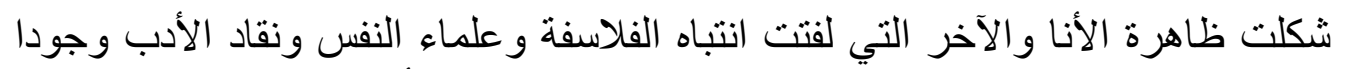

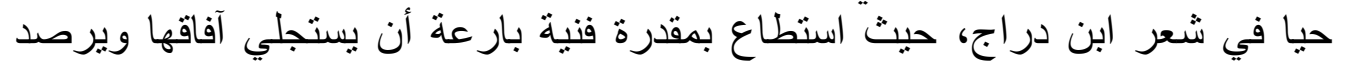
ملامحها من خلال عامرياته.

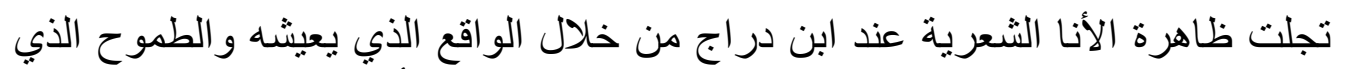

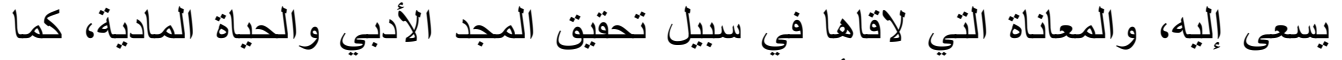

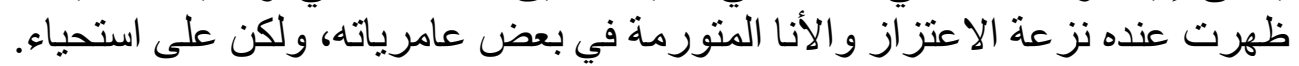

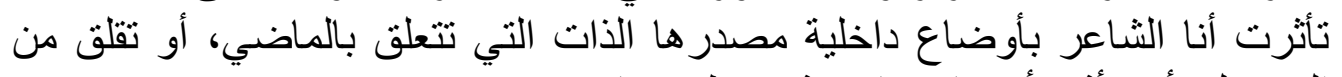

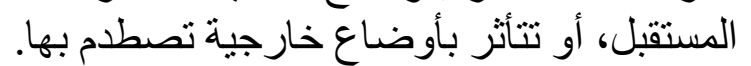

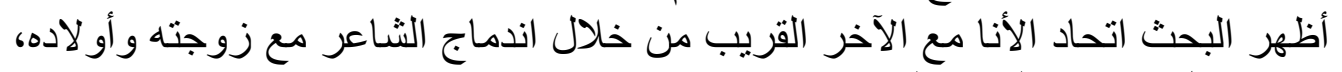

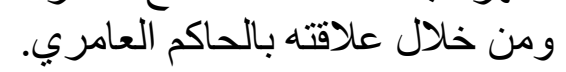
صور الشاعر الآخر العربي( المنصور بن أبي أبي عامر) من خلال نسبه وحسبه وطموحه

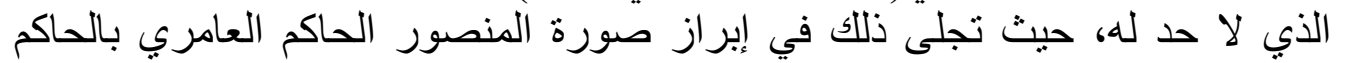

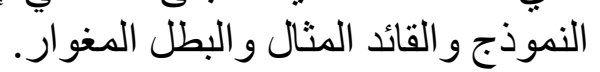

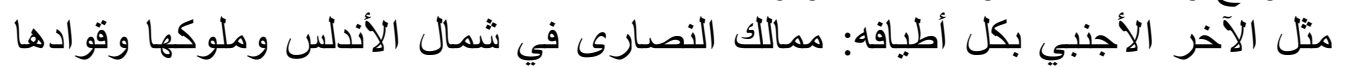

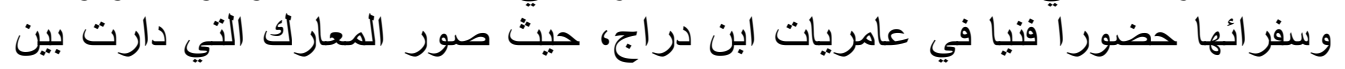


الحاكم العامري وتلاك الممالك، وسجل انتصار المسلمين، وكثيرا من الأماكن الأجنبية التي شهدت غزوات المنصور وانتصر فيها. المصادر والمراجع فئ

ابن الأبار: الحلة السيراء، تحقيق: د. حسين مؤنس، الثركة العربية للطباعة والنشر،

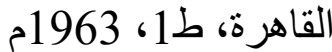
ابن الخطيب: كتاب إسبانيا الإسلامية أو كتاب أعمال الأعلام في من بويع قبل الاحتلام،

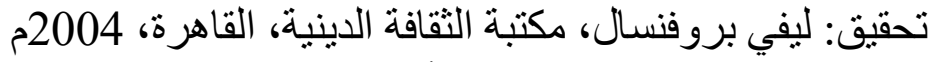
ابن بسام: الذخيرة في محاسن أهل الجزيرة، تحقيق: د. إحسان عباس، دار الثقافة،

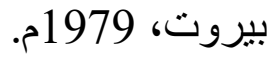
ابن بشكوال: الصلة في تاريخ أئمة الأندلس، نشر السيد عزت العطار، طبع القاهرة،

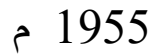
ابن حزم وابن سعيد والثقندي: فضائل الأندلس وأهلها، دار الكتاب الجديد، ابيروت، ابيان: المقتبس في أخبار بلد الأندلس، تحقيق: عبد الرحمن حجي، دار الثقافة،

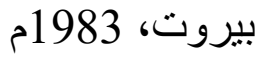
ابن خلكان: وفيات الأعيان و أنباء أبناء الزمان، تحقيق: د. إحسان عباس، دار صادر، ابيروت، دحية: المطرب من أثنعار أهل المغرب، تحقيق: إبر اهيم الإبياري وآخرين، دار العلم

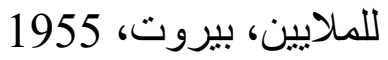
ابن دراج : ديوان ابن دراج، تحقيق: د. محمود علي مكي، المكتب الإسلامي بدمثق،

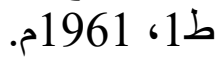
ابن سعيد: المغرب في حلى المغرب، ج1 ،2، تحقيق: د. شوقي ضيف، ط1، دار

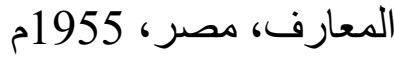
ابن عبد المنعم الحميري: الروض المعطار في خبر الأقطار، تحقيق: د. إحسان عباس،

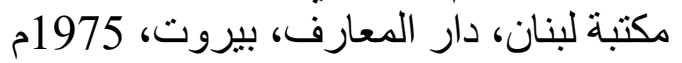
ابن عذاري: البيان المغرب في أخبار الأندلس والمغرب، الئن، تحقيق:ج س كولان، ليفي

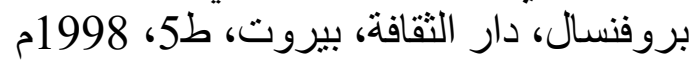
ابن منظور: لسان العرب، تحقيق: عامر حيدر، دار، عبد عبد المنعم خليل، دار الكتب

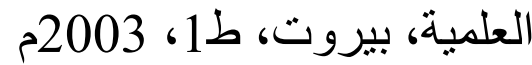
أبو الوليد الحميري: البديع في وصف الرئ الربيع، عناية: هنري بيريس، مكتبة الثقافة الدينية،

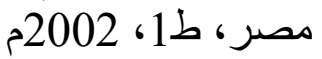
إحسان عباس، دكتور): تاريخ الأدب الأندلسي، عصر سيادة قرطبة، دار الثروق،

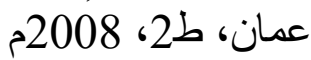

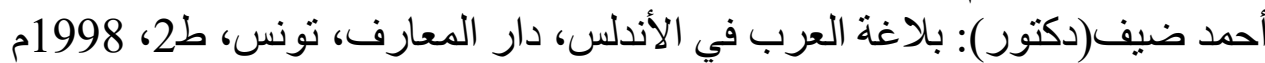

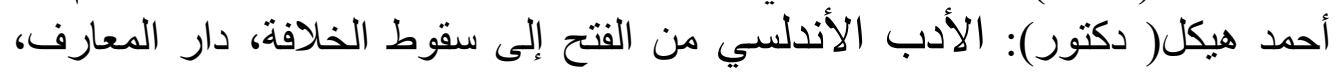

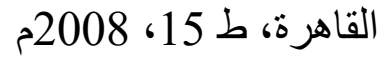
أحمد ياسين السليماني( دكتور): التجليات الفنية لعلاقة الأنا بالآخر في الثعر العربي

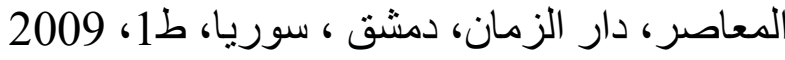

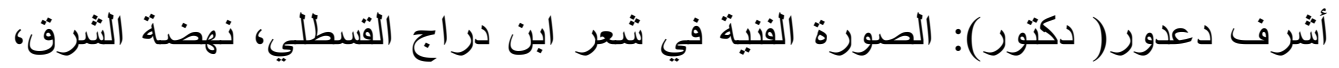

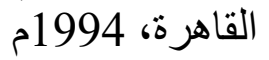




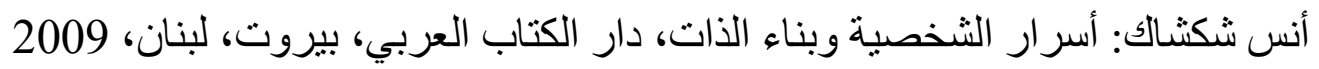
بالنثيا: تاريخ الفكر الأندلسي، ترجمة الدكتور حسين مؤنس، مكتبة النهضة النئة الدصرية،

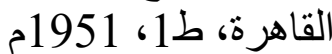
الثعالبي: يتيمة الدهر، تحقيق: د. مفيد محمد قميحة، دار الكتب العلمية، بيروت، ط1، 1983

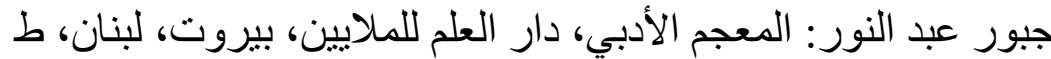

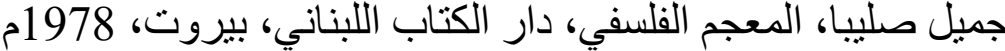
حازم القرطاجني: منهاج البلغاء وسر اج الأدباء، تحقيق: محمد الحبيب بن خوجة الكانة،

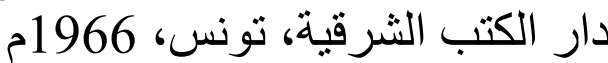
حبيب مونسي: فلسفة المكان في الثُعر العربي، قراءة موني، موضو عاتية جمالية، اتحاد الكتاب

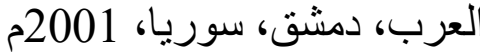
الحميدي: جذوة المقتبس في ذكر ولاة الأندلس، تحقيق: د. روحية السويفي، دار الكتب

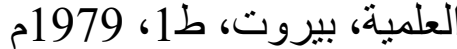

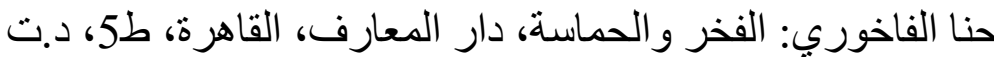

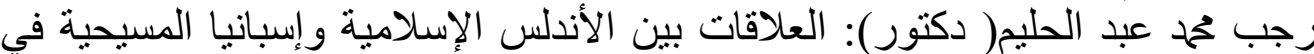

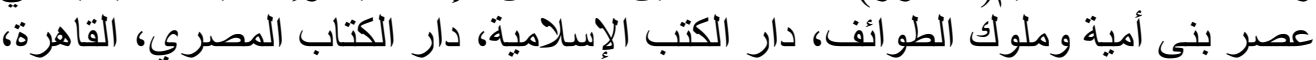

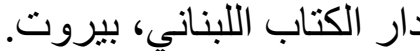
ز زكريا إبر اهيم( دكتور ): مشكلة الإنسان، دار مصر للطباعة، د.ت. لإن.

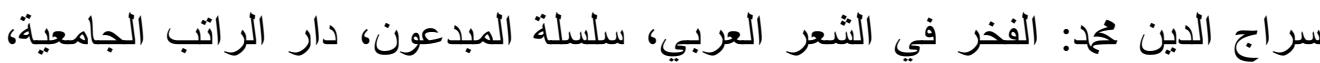

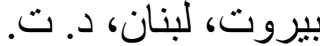

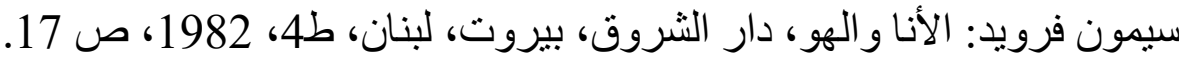

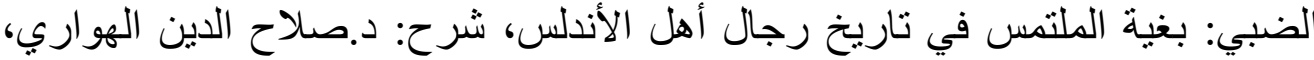
المكتبة العصرية، بيروت، ط1، بند 2005م

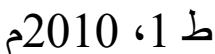

عبد الرحمن محم عيسوي( دكتور ): اتجاهات جديدة في علم النفس الحديث، دار النهضة

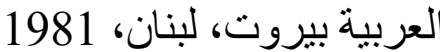
عبد اللطيف الحديدي( دكتور): بين الأنا والآخر في ددحيات المتنبي، جامعة الأزهر،

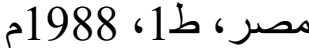

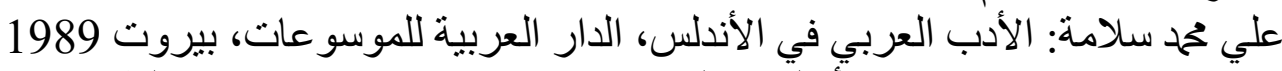

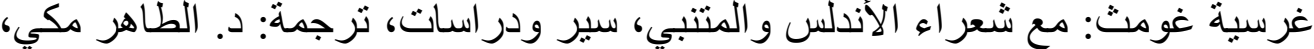

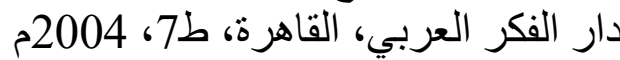
غرسية غومس: الشعر الأندلسي، ترجمة الدكتور حسين مؤنس، مكتبة النهضة

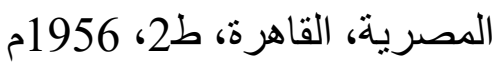
فوزي عيسى( دكتور): صورة الآخر في الثنعر العربي، مؤسسة عبد العزيز

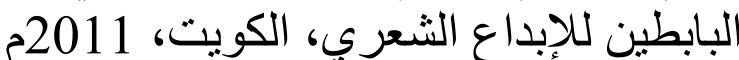
الكتاني: كتاب التشبيهات من أشعار أهل الأندلس، تحقيق: د. إحسان عباس، دار

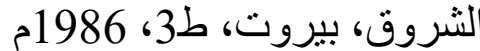
ليفي بروفنسال: تاريخ إسبانيا الإسلامية من الفتح إلى سقوط الخلافة القرطبية، ترجمة:

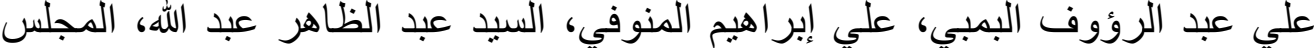

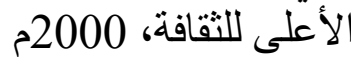
ماجدة حمود( دكتور): صورة الآخر في التراث العربي، منشور ات الاختلاف، بيروت 
• محمد الخباز : صورة الآخر في شعر المتنبي، المؤسسة العربية للار اسات والنشر، بيروت،

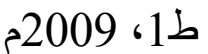
• مححم عبد الله عنان: الدولة العامرية وسقوط الخلافة الأندلسية، مطبعة مصر، القاهرة،

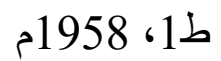
المر اكثي: المعجب في تلخيص أخبار المغرب، شرح: صلاح الدين الهواري، المكتبة

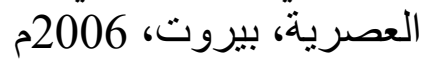

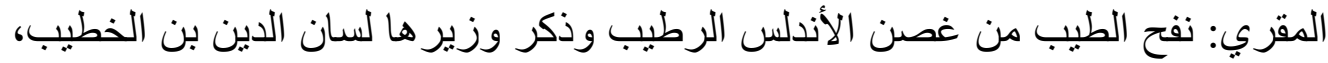

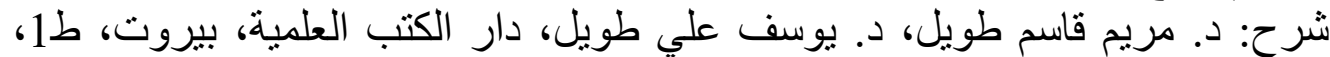

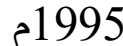
وزام قباني: عامريات ابن دراج القسطلي، منشورات الهيئة العامة السورية للكتاب،

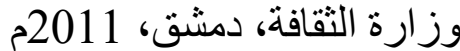

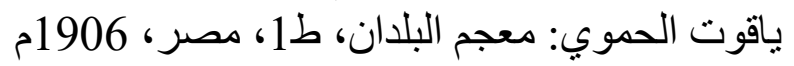

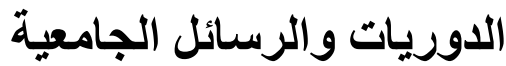

بلال سالم الهروط: صورة الآخر في أدب الرحلات الأندلسية، رسالة دكتوراه، جامعة

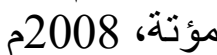

روضة بلال المولد: الاغتراب في حياة ابن دراج وشعره، رسالة ماجستير، جامعة أم

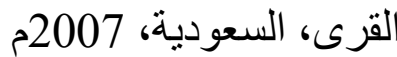
سعد سامي ححم: الأنا والآخر في المعلقات العشر، رسالة ماجستير، كلية الآداب، جامعة

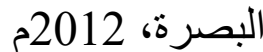

عائشة الدرهم( دكتور): العاطفة الأسرية في شعر ابن دراج، مجلة مركز الوثائق

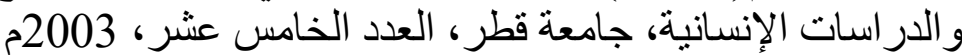

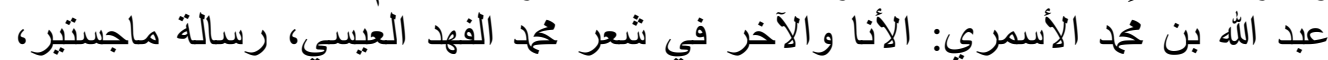

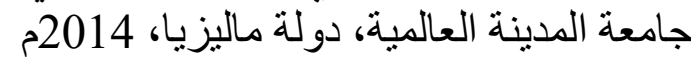
محمد دو اليبي: التجربة الثعرية عند ابن دراج القسطلي، رسالة دكتور اه، جامعة حلب، 2004 مي عودة أحمد ياسين: الآخر في الثعر الجاهلي، رسالة ماجستير، جامعة النجاح، كلية

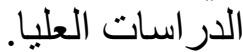
نو ال بر الك الثمالي: الذات والآخر في روميات أبي فراس الحمداني، رسالة ماجستير، جامعة أم القرى، ألمملكة العربية السعودية. 